DEPARTMEN'T OF THE INTERIOR

UNITED 'STATES GEOLOGICAL SURVEY

GEORGE OTIS SMITH, DIRECTOR

BULLETIN 359

\title{
MAGNETITE DEPOSITS OF THE CORNWALL TYPE
}

IN

PENNSYLVANIA

BY

AR'THUR C. SPENCER

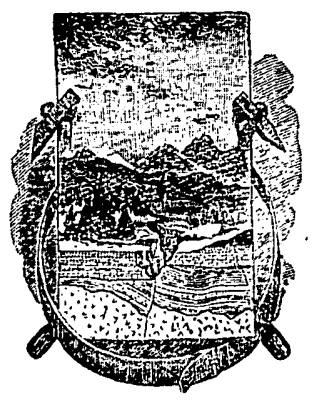

W A S H I N G'TON

GOVIRN MEN'T PRINTING OFEICE 1908 



\section{CONTENTS.}

rage:

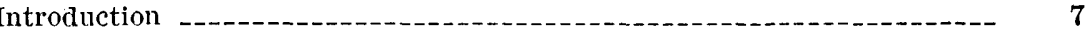

Geology of eastern Pennsylvania__._.

General statement._._. 7

Sedimentary rocks

Igneous rocks.-_-

General description of ore deposits

Composition of the ores

Distribution of the ores_._........ 12

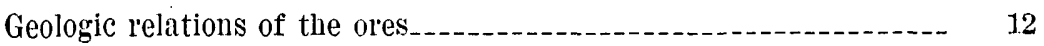

Origin of the ores_.

Replacements -...- 13

Source of the iron

Differential metamorphism

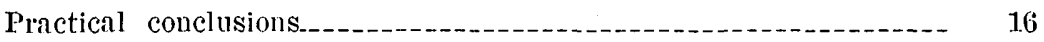

Cornwall and vicinity

Cornwall deposits__-_. 17

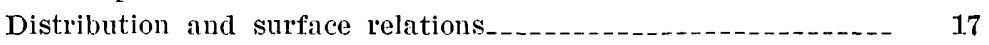

Diabase intrusions._-_._- 19

Structure of the beds___- 20

Extent of the deposits___-_.

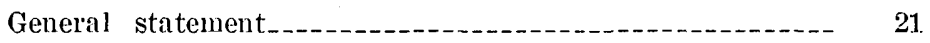

The Cornvall ore body

Near-by deposits__-_.-_- 23

Mines west of Cornwall

Carper deposit

Hummelstown deposits..._. 29

Berks County deposits__-_-__- 29

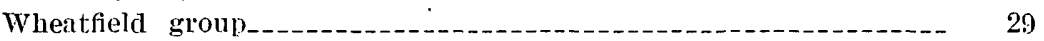

General description

Diabase intrusion

Character of the ores_..._.

Structure of the rocks_____ 31

Practical conclusions._-_- 34

Raudenbusch mine.-_-

Fritz Island and vicinity

Island mine _._. 38

East bank of Schuylkill River-_-_-_-_-_-_-_- 40

West bank of Schuylkill River-_-_-_-_-_-_.

Esterly mine_-_-_-_. 41

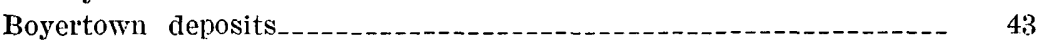

General description

Geology of the district_-_-_-_. 44

The workings._...- 47

Descriptions by Willis._._. 47 
Berks County deposits-Continued.

Page.

Boyertown deposits-Continued.

The workings-Continued.

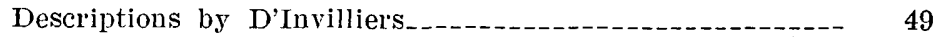

'Phoenix upper and middle slopes

Phoenix lower slope, or California mine

Warwick mine._........ 51

Gabel mine-_._. 53

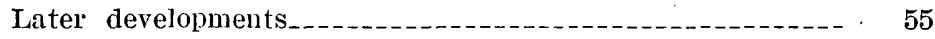

Practical conclusions_..._._....._. 57

Deposits southwest of Boyertown_..._. 61

Deposits north of Boyertown

Jones mine_-__-_._- 65

Warwick mine_._- 69

York County deposits___._-_._- 71

General statement_-_-_._._. 71

Dillsburg mines _._.

Introduction - -

Description of mines._._.

Logan mine_.............. 75

Cox mine

Price mine

Grove mine-_-_. 77

Prospects near Price farmhouse

Bell mine

King and Jauss mines................ 79

Altland mine_._._._. 81

Smyser mine

Underwood workings....... S3

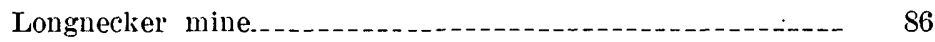

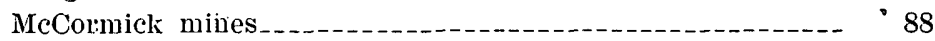

Diabase intrusions west of the mines_.................... 92

Practical conclusions___._. 93

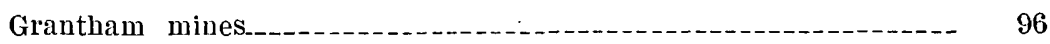

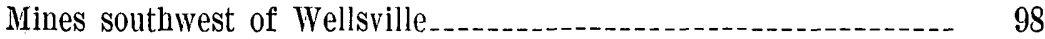

Bender mine

Index _....... 101 


\section{ILLUSTRATIONS.}

Prate I. Map of the Mesozoic belt in Pennsylvania

II. Geologic sketch map, vicinity of Cornwall_____________ 18

III. Structure sections, vicinity of Cornwall__- 20

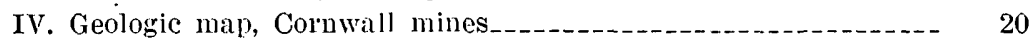

V. Geologic sketch map, district south of Reading _............ 30

VI. Geologic sketch map, vicinity of Wheatfield mines._.......... 32

VII. Map of Fritz Island mines__._.

VIIr. Surface map of Boyertown mines, showing position of ore

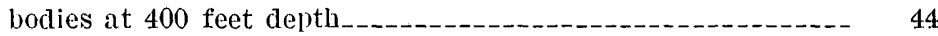

IX. Geologic sketch map, vicinity of Boyertown

X. General plan of workings, Boyertown mines_-_......... 46

XI. Cross section at Boyertown mines (along line A-B, Pl. X) -.-- 46

XII. Cross section at Boyertown mines (along line $C-D$, Pl. X) _... 48

XIII. Cross section at Boyertown mines (along line $E-F$, Pl. X) _-.- $\quad 50$

XIV. Cross section at Boyertown mines (along line $G-H$, Pl. X) .... 52

$\mathrm{XV}$. Cross section at Boyertown mines (along line $K-L$, Pl. X) -... 54

XVI. Plan showing position of fault, California and Warwick mines, Boyertown

XVII. Geologic sketch map, yicinity of Jones and Warwick mines...-

XVIII. 'Topographic map of vicinity of Jones and Kinuey mines.....-

XIX. Geologic sketch map of Mesozoic area near Dillsburg.........

Xx. Geologic and topographic map of Dillsburg iron-ore fields_.....

Fig. 1. North-south structure section 400 feet east of Ruth mine, wheatfield group.

8

)

0

0

32
$3 \mathrm{~S}$

4

4

6

6

8

0

2. North-south structure section near slope No. 1, Wheatfield group.

3. East-west structure section, Wheatfield group

4. Sketch section at north end of Fritz Island__._.

5. Sketch section along river bank east of Fritz Island mines_-_-_-

6. Plan of upper level of Warwick mine, Boyertown

7. Sketch. showing possible structure between Hagy and Eastern veins

8. Sketch section illustrating relations of Black vein and diabase sill__________

9. Geologic sketch map of vicinity of Boyertown

10. Geologic sketch map of region northeast of Boyertown-_-_...-

11. East-west structure section, Jones mine_._.

12. North-south structure section, Jones and Kinney mines...-_.....

13. East-west structure section, Kinney mine_-

14. Structure section, Warwick mine_.

15. Plan and sections of Bell mine...

16. Surface plan showing probable structure at Bell mine........

17. Survey of workings, Jauss mine

18. General structure section, Jauss mine

19. Map of Underwood and Iongnecker mines, showing luobable trend of ore bed.

20. Plan and section of Iongnecker mine__._. 87

21. Sketch map showing situation of pits and test holes on McCormick tract. 



\title{
MAGNETITE DEPOSITS OF THE CORNWALL TYPE IN PENNSYLVANIA.
}

\author{
By Arthur C. Spencer.
}

\section{INTRODUCTION.}

The deposits of iron ore which form the subject of the present report occur near the edges of the belt of Mesozoic rocks which enters Pennsylvania along Delaware River above Trenton, N. J., and extends across the State in a general southwesterly direction to the Maryland line. Thov $\mathrm{gh}$ the deposits have been described by several geologists the present study was undertaken in the belief that an investigation of somewhat broader scope than any of those previously attempted might lead to an understanding of the manner in which the ores were formed, and that a knowledge of their genesis might warrant practical suggestions looking to the discovery of ore bodies as yet unknown. The work has been somewhat disappointing, because the observed facts do not establish a complete theory regarding the origin of the ores, but from a practical standpoint the results are thought to be of value.

The older descriptions deal mainly with those relations of the ore bodies exhibited in the mines or pits from which ore was being extracted, but the deposits are here considered in the light of their geologic setting. The writer has used much of the information recorded by earlier geologists and has quoted some of their statements, to which many of his own observations are merely supplementary. The field work was done during the autumn of 1906 and the summer of 1907.

\section{GEOLOGY OF EASTERN PENNSYLVANIA.}

GENERAL STATEMENT.

The rocks of Pennsylvania, as recognized by the first State geologist, H. D. Rogers, fall naturally into three main divisions-the pre-Cambrian gneisses, schists, and volcanic rocks; the Paleozoic stratified formations; and the Mesozoic stratified formations with 
associated igneous rocks. All these divisions are represented in the southeastern portion of the State, in the region covered by Franklin, Adams, York, Chester, Lancaster, Dauphin, Lebanon, Berks, Montgomery, Delaware, Philadelphia, Bucks, and Lehigh counties, though the pre-Cambrian and Mesozoic rocks are confined to the region which lies southeast of the Allegheny Mountain front and to the limestone valley which trends from southwest to northeast through Cumberland, Dauphin, Lebanon, Berks, and Lehigh counties.

By folding and faulting the original surface between the ancient crystalline rocks and the lowest Paleozoic beds has been complexly contorted and broken, so that great masses of the Paleozoic formations are downset into the basement rocks. In four districts deep erosion of relatively upthrown blocks has revealed the pre-Cambrian formation. In Franklin and Adams counties the pre-Cambrian rocks of South Mountain are largely of volcanic origin. They are here intricately infolded with Paleozoic quartzites and limestone. In the vicinity of Philadelphia and southwestward from that city the pre-Cambrian rocks include schists and massive igneous intrusions. In northern Chester County and in Berks and Lehigh counties they are mainly granular gneisses.

\section{SEDIMENTARY ROCKS.}

Of the many Iormations which are comprised in the whole of the Pennsylvania Paleozoic section only the Cambrian quartzites, the Cambro-Ordovician limestones, and the Ordovician shales occur in the region here under discussion. In the following pages these divisions of the Paleozoic sequence are designated as "No. I" sandstone, "No. II" limestone, and "No. III" shale, in accordance with the usage of the Second Geological Survey of Pennsylvania. Taken together, formations "I " to." III" extend over a belt of country from 10 to 20 miles wide, lying southeast of the Allegheny Front. The limestone, being relatively much thicker than the sandstone, is the more prominent of the two, while, as the uppermost of the three members, the shale has been more extensively removed by erosion than the limestone and sandstone.

The Mesozoic strata, made up principally of coarșe-grained red sandstone and red shale, are distributed in a belt from 8 to 12 miles wide, extending from Delaware River in a southwesterly direction to the Schuylkill, thence westward to the Susquehanna, and from the Susquehanna again southwestward to the boundary between Pennsylvania and Maryland. Locally, heavy beds of limestone conglomerate are present.

Though these red formations are now commonly designated the Newark group, they are here called simply Mesozoic, the term being 


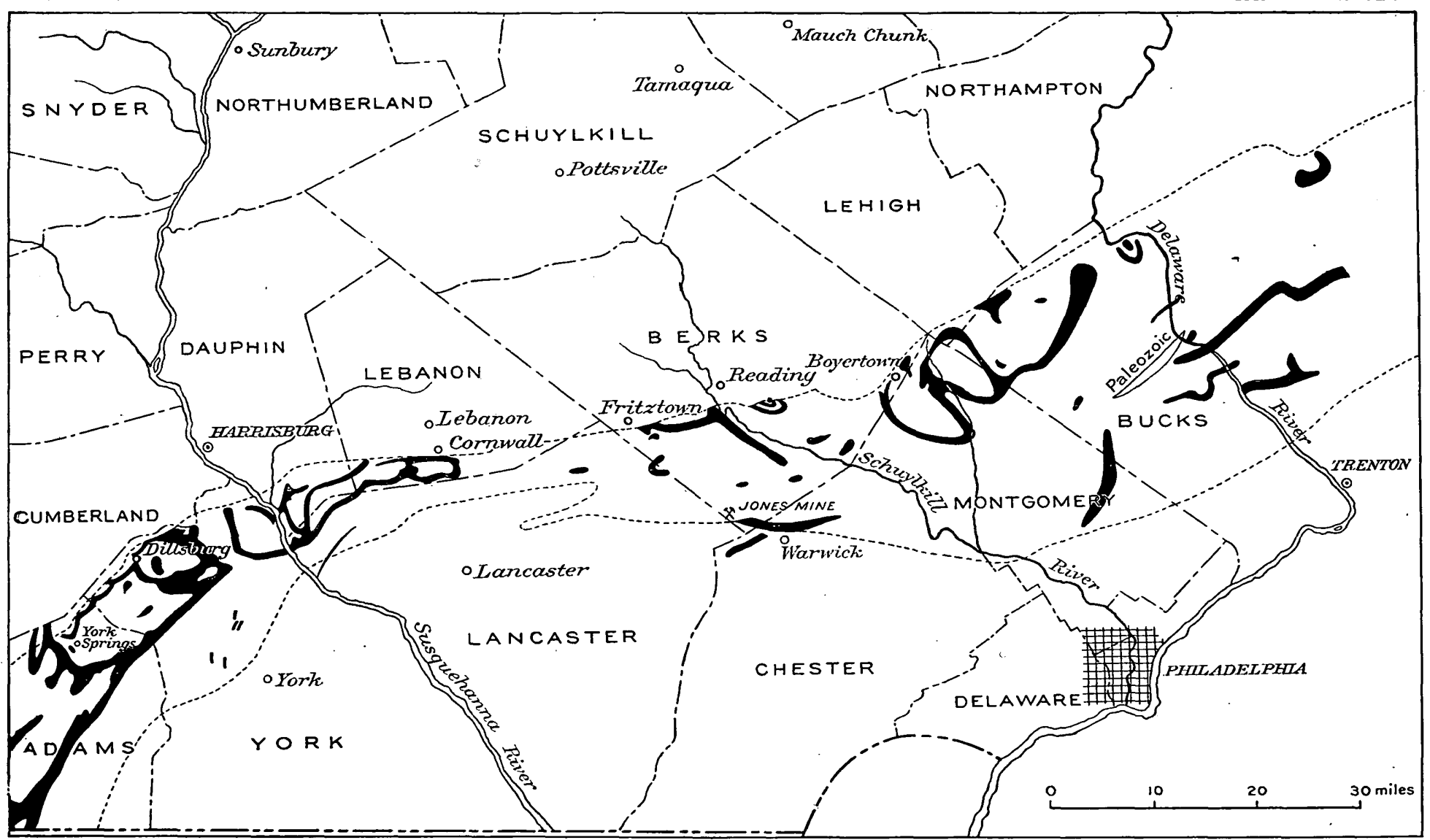

MAP OF THE MESOZOIC BELT IN PENNSYLVANIA, SHOWING PRINCIPAL INTRUSIONS OF DIABASE. Data in part from Second Geological Survey of Pennsylvania. 
consistent with Paleozoic, which it has been found convenient to employ in the descriptions that follow. Considered in reference to other stratified Mesozoic formations which overlap the Newark rocks in eastern New Jersey, the latter are properly designated as lower Mesozoic, but failure thus to particularize their position in the stratigraphic column leads to no confusion in discussing the geology of Pennsylvania.

The belt of Mesozoic rocks in eastern Pennsylvania is part of an unbroken curving zone about 300 miles in length, extending from the west shore of Hudson River across New Jersey, Pennsylvania, and Maryland, and into Virginia as far as Culpeper County. Several outliers in the continuation of the general course of this belt are found in southern Virginia and in North Carolina, while northward from Hudson River there is an extensive basin of corresponding rocks in the valley of Connecticut River, and another bordering the southeast side of the Bay of Fundy in Nova Scotia.

In Pennsylvania the Mesozoic strata were deposited upon a previously eroded surface on which were exposed all the older rocks now represented in the region. In places along the borders of the Mesozoic belt pre-Cambrian gneisses are present. Elsewhere "No. I" sandstone or "No. III" shale is overlapped by the Mesozoic strata, but on the whole "No. II" limestone forms the usual basement. Bowlders entering into the make-up of the limestone conglomerates that occur in places along the edge of the belt have evidently been derived from the formation last mentioned.

IGNEOUS ROCKS.

The zone comprising the various Mesozoic basins is characterized by intrusions of diabase or surface flows of basalt, both of which are commonly called trap rock, or simply trap (Pl. I). The diabase dikes occur in the districts between the several basins, and southward along the general trend of the zone they persist across South Carolina and well into Alabama. Although the strip of country in which the dikes are present is considerably wider than any of the separate belts of Mesozoic strata, the great bulk of the igneous material is associated with the Mesozoic rocks. In New England and New Jersey both extensive surface flows and invading masses are present, but in Pennsylvania nearly all of the igneous rock is distinctly intrusive. The intrusions are mainly sills which follow the bedding of the invaded formations more or less closely, but local and even extensive crosscutting may be observed.

As the igneous material could not have originated either within the mass of the Mesozoic sediments or within the underlying Paleozoic formations, a deep-seated source must be admitted. In order to have 
reached the positions which it now occupies the diabase must have come up through channels traversing the lower Mesozoic strata and the basement rocks beneath them. Presumably the ordinarily narrow dikes that occur outside of the Mesozoic belt were feeders for intrusive sills and for surface flows associated with portions of the Mesozoic sediments which have been removed by erosion. If this be true the feeders of the sills that still remain are perhaps for the most part similar narrow dikes.

The ore deposits described in the following pages are intimately associated with intrusive masses of diabase and most of them are contained in calcareous strata, either in the limy rocks belonging to Paleozoic "No. II" limestone, outcropping near the edge of the Mesozoic belt, or in the beds of limestone conglomerate that locally mark the base of the Mesozoic section. Since the deposits are situated in each case near the surface of unconformity between the Mesozoic and the underlying Paleozoic formations, there is reason to believe that the diabase masses associated with the ores are bodies which cut across the Paleozoic basement rocks. These masses are of considerable size. Some of them were evidently the feeders of sills which penetrate the Mesozoic strata.

\section{GENERAL DESCRIPTION OF ORE DEPOSITS.}

The Cornwall type of iron ore is so called from the important Cornwall mine in Lebanon County, Pa. The ores are essentially magnetite, but they contain pyrite in amounts which make it necessary to roast them before they can be used in the blast furnace. Some specular hematite occurs in certain of the mines, but the amount of this mineral is relatively unimportant.

The ore occurs in large and small masses of varying form, either entirely inclosed by stratified sedimentary rocks or lying in such rocks where they come in contact with masses of intrusive diabase. The ore minerals appear to have been formed by more or less complete chemical substitution in the body of the rock, the portion of the rock not replaced constituting the principal gangue of the ore. Aside from the deposition of the iron minerals the limy strata associated with the ore bodies show remarkably little metamorphism, and though a few characteristic minerals of contact metamorphism occur they are so uncommon as to almost escape observation. The Cornwall mines have yielded more than $20,000,000$ tons of ore, from what is essentially a single great ore body, though it contains extensive partings of barren rock. The other deposits are all much smaller, though several of them are still of important size. 


\section{COMPOSITION OF THE ORES.}

The iron content of these ores is extremely variable, but as the ore is mined probably averages not far from 45 per cent. Rather constant chemical characteristics are low phosphorus, high sulphur, silica, lime, and magnesia, and the presence of copper. Small amounts of cobalt have been found in ores from Cornwall and Dillsburg. Many analyses of ore from the different mines may be found in the reports of the Pennsylvania Geological Survey, from which the following are extracted:

Partial anulyses of Cornuall ore.

[A. S. McCreath, analyst.]

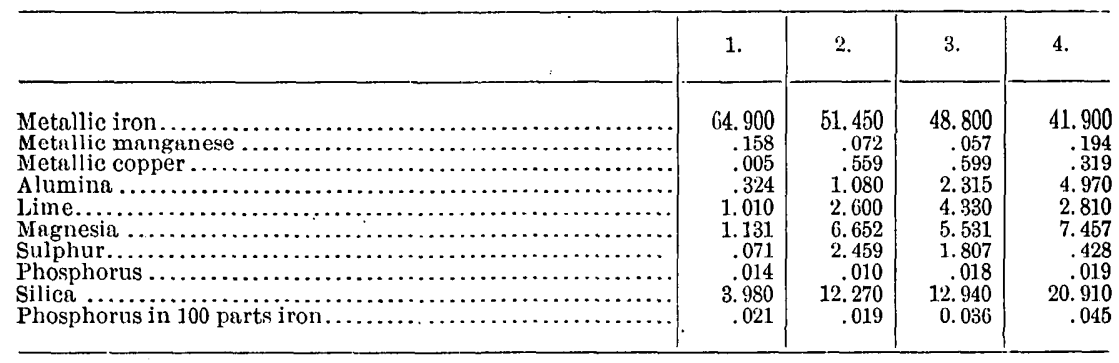

a Lesley, J. P., and D'Invilliers, E. V., Cornwall iron ore mines : Ann. Rept. Second Geol. Survey Pennsylvania for 1885,1886 , pp. 532, 533.

1. Analysis of $\mathbf{1 1 5}$ pieces of niggerhead ore from Middle Hill.

2. Analysis of fine or soft No. 3 ore from west cut, north side, Middle Hill,

- 3. Analysis of "No. 1 ore" from east face, Middle Hill.

4. Analysis of "No. 1 light ore" from west cut, south face, Middle Hill.

All the above were dried at $212+{ }^{\circ} \mathrm{F}$. before snalysis.

Partial analyses of ores from Berks and York counties. ${ }^{a}$

\begin{tabular}{|c|c|c|c|c|c|c|}
\hline & 1. & 2. & 3. & 4. & 5. & 6. \\
\hline 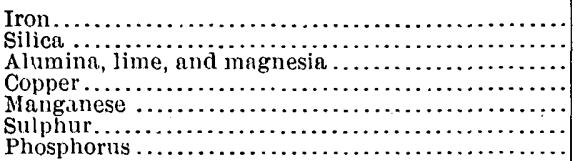 & $\begin{array}{r}43.40 \\
11.13 \\
18.90 \\
.01 \\
.01 \\
.43 \\
.09\end{array}$ & $\begin{array}{r}43.00 \\
14.02 \\
13.86 \\
.59 \\
.5 \\
.53 \\
.02\end{array}$ & $\begin{array}{r}42.75 \\
22.10 \\
11.45 \\
\cdots \\
\cdots \\
.59 \\
.01\end{array}$ & $\begin{array}{r}39.60 \\
20.20 \\
19.18 \\
.12 \\
.23 \\
1.94 \\
.06\end{array}$ & $\begin{array}{r}38.05 \\
16.13 \\
19.77 \\
.56 \\
.42 \\
1.14 \\
.04\end{array}$ & $\begin{array}{r}34.55 \\
21.21 \\
22.38 \\
.17 \\
.21 \\
1.64 \\
.03\end{array}$ \\
\hline
\end{tabular}

${ }^{a}$ Lesley, J. P., and D'Invilliers, Ii. V., op. cit., p. 537.

1. Black ore, 163 pieces, from Warwick mine, Boyertown, Berks County, A. S. McCreath.

2. Magnetic ore from Island mine, Reading, slope No. 1, Leonard Peckitt, Reading.

3. Dillsburg ore from A. Underwood's mine, A. S. McCreath.

4. Magnetic ore from Wheatfield mine, Berks County.

5. Magnetic ore, 25 pounds, from Island mine, Reading, A. S. McCreath.

6. "Blue ore," 20 pounds, from Phœnix mines, Boyertown, A. S. McCreath.

Workings at the surface formerly furnished soft ore free from sulphur, but this material gives place to hard sulphurous ore at relatively shallow depths. 


\section{DISTRIBUTION OF THE ORES.}

So far as known, ores of the Cornwall type do not occur outside of Pennsylvania, though certain small veins of magnetite occurring in masses of intrusive diabase in Nova Scotia may be more or less closely related to them. In Pennsylvania the ores have been mined on a considerable scale at five localities in Berks County, namely: At Boyertown; at two places south of Reading; 7 miles southwest of Reading, near Fritztown; and near Joanna station, $2 \frac{1}{2}$ miles northeast of Morgantown. In Chester County they were formerly mined at Warwick, though this deposit is entirely exhausted. The great Cornwall mines are situated in Lebanon County, and near them are two other small deposits. In York County a large number of operations have been carried on in the vicinity of Dillsburg. Of all the deposits which have been mentioned only the one at Cornwall is now worked in a large way, though the several interests which formerly controlled the Boyertown properties have recently been consolidated so that these mines may be started at an early date. At Dillsburg some ore was mined in 1903, and surface mining on a small scale was in progress at the Wheatfield group in 1906; the other mines have been abandoned for many years.

\section{GEOLOGIC RELATIONS OF THE ORES.}

Though in the past there has been considerable discussion concerning the stratigraphic position of the deposits, it is now agreed that in York County they lie in Mesozoic strata and in most of the other localities in limestones or limy shales of Paleozoic age. ${ }^{a}$

The Cornwall deposit is situated at the top of "No. II" limestone of the Pennsylvania section, just under the "No. III" ("Hudson") shale; the Boyertown, Fritz Island, Raudenbusch, Wheatfield, and Jones deposits are in strata which apparently belong near the base of "No. II" limestone. The Warwick deposit lies at the base of Mesozoic beds that rest upon pre-Cambrian gneisses.

It has been found that large masses of intrusive diabase are present near each of the existing ore bodies and usually in actual contact with them. The existence of diabase near the mines is noted in every published description of these magnetite deposits, and the present investigation has served to emphasize both the size of these igneous masses and the importance of their relation to the ore deposits. It is thought, indeed, that the origin of the ores must have been directly connected with the intrusion of the igneous rocks.

\footnotetext{
a Lesley, J. P., and D'Invilliers, E. V., op. cit. Also, D'Invilliers, E. V., Iron ore mines and limestone quarries of the Cumberland-Lebanon Valley: Ann. Rept. Second Geol. Survey Pennsylvania for 1886, pt. 4, 1887.
} 


\section{ORIGIN OF THE ORES.}

\section{RFPLACEMENTS.}

If the various deposits be considered together the theory of origin which seems to be required by their geologic relations is that the magnetite ore bodies of the Cornwall type have been formed by the more or less complete metasomatic replacement of sedimentary rocks by iron minerals precipitated from heated solutions set into circulation by the invading diabase. The rocks which have been thus replaced are usually limestones, limy. shales, or limestone conglomerates.

Previous writers, including H. D. Rogers, T. Sterry Hunt, Persifor Frazer, jr., J. P. Lesley, and E. V. d'Invilliers, have held that while the present magnetic condition of the ores might be due to the metamorphosing effect of the trap rocks (diabase), the deposits had been formed before the introduction of these rocks. ${ }^{a}$

Material from almost any one of the mines affords abundant evidence that the ore minerals have been deposited by substitution or chemical' replacement of the limy rocks. Much of the lean ore consists of alternating layers of the iron minerals and unaltered rock, showing definitely that certain portions of the rock have.been more favorable for replacement than others. At Cornwall many examples may be seen in which thin layers of ore conforming to the stratification of the limy shales are connected by cross seams, which show beyond a doubt that the ore minerals could not have been formed contemporaneously with the inclosing rock, but that they must have been introduced subsequently. It is the writer's conception that the solutions which accomplished the deposition of the ores must have been in the condition of vapor when they penetrated the rocks.

SOURCE OF THE IRON.

The source of the solutions concerned in the formation of the ores and in the general metamorphism of the rocks in the vicinity of the igneous masses and the source of the iron which the deposits contain can not be satisfactoridy determined. The observed facts lead to no definite conclusion on either of these points, though, all things con-

${ }^{a}$ Rogers, H. D., Geology of Pennsylvania, vol. 2, 1858, pp. 687, 708, 718.

Hunt, 'T. S., The Cornwall iron mine and some related deposits in Pennsylvania: Trans. Am. Inst. Min. Eng., vol. 4, 1875, pp. 508-510.

Frazer, P., jr., Second Geol. Survey Pennsylvania, Rept. CC, 1877, pp. 198-400. Also, A study of the specular and magnetic iron ores of the new red sandstone in York County, Pa.: Trans. Am. Inst. Min. Eng., vol. 5, 1877, pp. 132-143.

Lesley, J. P., and D'Invilliers, E. V., Report on the Cornwall iron-ore mines, Lebanon County: Ann. Rept. Second Geol. Survey, Pennsylvania, for 18S5, 1886, pp. 491-570; Final Rept. Second Geol. Survey Pennsylvania, vol. 1, 1892, pp. 351-357.

D'Invilliers, E. V., The Cornwall iron-ore mines, Lebanon County, Pa.: Trans. Am. Inst. Min. Eng., vol. 14, 1886, pp. 473-904. 
sidered, if it be admitted that the heat of the intrusive rocks was the prime cause of the circulation of the solutions which formed the ore it appears more likely that both the waters and the iron were furnished by the igneous rock than that they could have been derived from an outside source. Possibilities which naturally present themselves are as follows:

1. The water was of meteoric origin and the iron came from the sedimentary rocks.

2. The water was of juvenile origin (that is, it was expelled from the igneous rocks) and the iron came from the sedimentary rocks.

3. The water was of juvenile origin and contained the iron in solution when it escaped from the igneous rocks.

The suggestion that ordinary ground waters could have been heated by the invading igneous rocks and thus have been enabled to cause extensive induration of the invaded Mesozoic strata, leaching them of their contained iron and concentrating it into ore deposits occupying the observed situation, is opposed by several considerations. In the first place, it appears that waters from any source outside of the igneous rock, whatever their natural courses of circulation, if unaffected by the intrusive masses, could never closely approach the heated bodies of rock, for the reason that steam. would be generated in the vicinity of the contacts and the resulting pressure would tend to drive all waters outward from the source of heat. Under such conditions if ore deposits were formed they would not be segregated at the igneous contacts, but instead would be some distance away, which is contrary to the existing relations. A second argument against the suggestion is that the deposits are neither as numerous nor as widely distributed as would be expected if the iron had been contributed by the invaded formations. The only sedimentary rocks which can be considered as at all competent to have furnished sufficient iron for the known deposits are the Mesozoic sandstones and shales that occur in the vicinity of all the deposits, as the Paleozoic formations are made up of rocks containing very small amounts of iron. In so far as they have not been altered by the influence of the intrusive diabases the Mesozoic rocks are of almost uniform appearance throughout the region and from a few recorded analyses it may be judged that they carry from 5 to 8 per cent of iron oxide. Everywhere in the neighborhood of the intrusive masses the sandstone and shales have been extensively metamorphosed. In places balls of epidote have been. formed in the shales; elsewhere small segregations of specular hematite occur in coarse sandstones; and in conglomerates some of the pebbles are surrounded by rims of garnet, tremolite, and hornblende. Changes of this sort characterize the more intense phases of metamorphism and are observed only near the diabase contacts; more exten- 
sive alteration of a less striking nature is manifested by a general induration of the rock and by a loss of the original red color.

Though the general bleached condition of the Mesozoic strata in the neighborhood of the intrusive masses points to these rocks as a possible source of the segregated iron, it is not certain that the whitened rocks have actually lost their iron, for the original amount of this element may still be present in a different chemical state. No investigation has been made to settle the question thus raised, but it does seem that if the iron of the sandstones has been depleted in a few places the same thing must have taken place generally, because the appearance of the altered rocks is the same in many places. If the known deposits of iron ore had been formed from solutions of this origin a certain amount of segregation should be found in association with the bleached rocks wherever they occur. The fact that the ore deposits are so localized is thus against the idea that the iron which they contain has been furnished by the sedimentary rocks.

The conclusion that the sedimentary rocks are not likely to have furnished the iron applies as well when the active waters are regarded as having come from the igneous rocks as it does when a meteoric source is assigned to them.

It can hardly be doubted that the general alteration of the shales and sandstones near the igneous rocks has resulted from the action of heated water and steam percolating through the sandstones and shales. If the waters which took part in the metamorphism had come out of the igneous rocks, either from the masses adjacent to the altered sediments or from much deeper masses which have not been exposed to view, they could hardly have made an excursion through the stratified rocks and later returned to the contact, as they must have done to have deposited the ore bodies at Boyertown, at Cornwall, at the Jones mine, and at the larger ore beds of the Dillsburg field.

Only one of the several adverse considerations presented above stands in the way of the suggestion that both the waters which effected the metamorphism and the iron which was deposited by these waters were driven from the igneous rocks; namely, the uncommonness of the deposits. If certain of the intrusive masses furnished iron for large deposits, why is it that similar segregations do not occur in association with every important mass of diabase? Though the question can not be satisfactorily answered, our general knowledge concerning the occurrence of ore deposits at igneous contacts points to the conclusion that the nature of the solutions given off by different parts of igneous rock masses is subject to wide variation, so that it is by no means necessary to believe that identical materials must have been introduced everywhere in the vicinity of intrusive 
masses of the diabase, even though the igneous rock be accepted as the source of the iron segregated locally at the contact with the invaded strata.

\section{DIFFERENTIAL METAMORPHISM.}

Whatever the actual source of the iron may have been, it can not be doubted that different masses of diabase within the same general field may have differed greatly in respect to efficiency in producing metamorphism, but, other things being equal, it can be assumed that the directness of the paths by which the intrusions came into their present positions must have been a very important factor influencing the relative amount of alteration and mineralization which the various masses of diabase were capable of producing. It seems evident that the transfer of heat and the movement of mineralizing waters must have continued for a much longer period in the vicinity of strongly crosscutting masses of igneous rock than adjacent to others having less direct connection with the deep-seated reservoir which supplied the molten rock material. This is accepted because the deep reservoir is conceived to have been the original source of all the energy involved in the chemical reactions of metamorphism and ore deposition.

\section{PRACTICAL CONCLUSIONS.}

The geologic features of the various deposits which have been studied are thought to warrant the following general suggestions to those who in the future may make practical explorations for new ore bodies in this field.

1. Ore bodies are to be sought only on or near the walls of masses of diabase.

2. Large masses of diabase are more favorable for ore deposits than smaller masses.

3. Crosscutting intrusions and highly inclined sills are more favorable than sills of low inclination.

4. Limestones and limy shales are far more likely to be replaced by ore than clay shales or sandstones.

5. Particularly favorable locations for ore are found in masses of limestone that lie between bodies of diabase and beds that are in a marked degree less susceptible than limestone to the metamorphosing influence of the igneous rocks.

6. The most promising situations will be found at places where the largest number of the above-stated favorable conditions occur in combination.

Many or all of the more favorable conditions enumerated existed at places where the larger ore deposits of the Cornwall type were formed, and as several of these conditions may be fairly inferred 
to exist in a few other localities, usually in the vicinity of the mines which have been operated, still other deposits of iron ore may yet be found in the same field. The geologic descriptions which follow have been prepared with especial reference to the possibility of indicating situations in which it may prove. worth while to look for deposits of iron ore as yet unrecognized.

\section{CORNWALL AND VICINITY.}

\section{CORNWALL DEPOSITS.}

\section{DISTRIBUTION AND SURFACE RELATIONS.}

The Cornwall ore banks are situated 5 miles from Lebanon, Pa., on the south side of the Lebanon Valley, along the edge of which Paleozoic limestones and slates give place to intrusive diabase and to conglomerates, sandstones, and shales of Mesozoic age (Pl. II). The different formations have a general east-west trend through all this region, and for several miles both east and west of Cornwall the older (Paleozoic) and newer-(Mesozoic) formations are separated by an intrusive mass of diabase which has a width in outcrop of 1,400 to 2,900 feet. The mines lie just south of this diabase in an isolated area of limestone, the southern boundary of which is formed by overlapping Mesozoic beds. Eastward from the ore hills for a distance of somewhat more than a mile a narrow strip of slaty rocks comes between the diabase and the lowermost Mesozoic strata exposed in this vicinity. West of the workings a narrower strip of the same rock in similar position outcrops for perhaps 1,000 feet. The limestones and interlayered limy shales south of the diabase have been more or less completely replaced by magnetite, somewhat contaminated by pyrite and chalcopyrite, and it is these impregnated strata that constitute the great deposit from which more than $21,000,000$ tons of iron ore have been extracted since 1853 .

The position and surface relations of the ore-bearing strata to the various rocks which have been spoken of in the foregoing paragraph are clearly exhibited on the maps (Pls. II and IV), and the crosssections (Pl. III) indicate the supposed relations underground. These sections are intended to show the kind of structure that seems to be required by the existing surface distribution of the various kinds of rocks and by their strikes and dips, in so far as these can be observed. As guides the sections are believed to be of some value, but thicknesses, strikes, and dips of buried strata are manifestly not ascertainable factors in cases like the present, where masses of intrusive rock, and in addition a great unconformity of deposition, are involved in the structure to be interpreted.

$54370-13$ ull. $359-05-2$ 
On the surface the ore, together with such masses of lean or barren rock as accompany it, is bounded on the west, north, and east by diabase, a tongue of which likewise limits the Big Hill mine on the south. Between the tongue of diabase that forms the southern side of Big Hill and the first exposure of Mesozoic beds in the low ground immediately south of Miners village the slope is covered by loose débris, so that it is impossible to say what the distribution of the various rocks actually is. It seems very likely, however, that some of the strata which are elsewhere converted into ore occupy at least a portion of this hidden ground. South of the mines scattered outcrops serve to indicate rather closely the northerly limit of the Mesozoic rocks, the lowest bed of which is a conglomerate composed of angular quartz fragments in a cement of bluish clay. This peculiar rock has been called porphyry by casual observers, but its clastic nature is obvious on close examination. South of the present workings in Middle Hill, and for some distance toward the west, loose débris derived from the near-by hill covers the edge of the ore, but the blue conglomerate has been revealed in a reservoir excavation near the Mount Hope road, and this rock probably constitutes the immediate capping of the ore-bearing strata from this place eastward to the exposures along the railroad track just below the superintendent's office. West of the Mount Hope road the same rock may be followed for some distance, but in this direction its outcrop approaches the diabase, and the rock is considerably baked and indurated. On the little knoll just west of the road a narrow strip of slate is present next to the diabase, as previously mentioned.

The blue conglomerate appears to lie at the bottom of a series of carbonaceous shales which are partially exposed along the Mount Hope road, and are well exhibited 2 miles farther west in a cutting along the Cornwall and Lebanon Railroad. On the geologic maps (Pls. II and IV) the conglomerate and carbonaceous shales are represented by one pattern.

The area over which the ore-bearing strata were naturally exposed or have been revealed by stripping is roughly 4,000 feet long and from 400 to 800 feet wide, and its extent beneath a superficial covering of loose gravel and sandstone débris, though as yet not fully determined, would seem to be considerably more. From diamond-drill borings south of the present workings it is known that ore continues in this direction for at least several hundred feet beyond the edge of the Newark strata that cap the deposit, but the information afforded by these holes has not been available in the present study. 


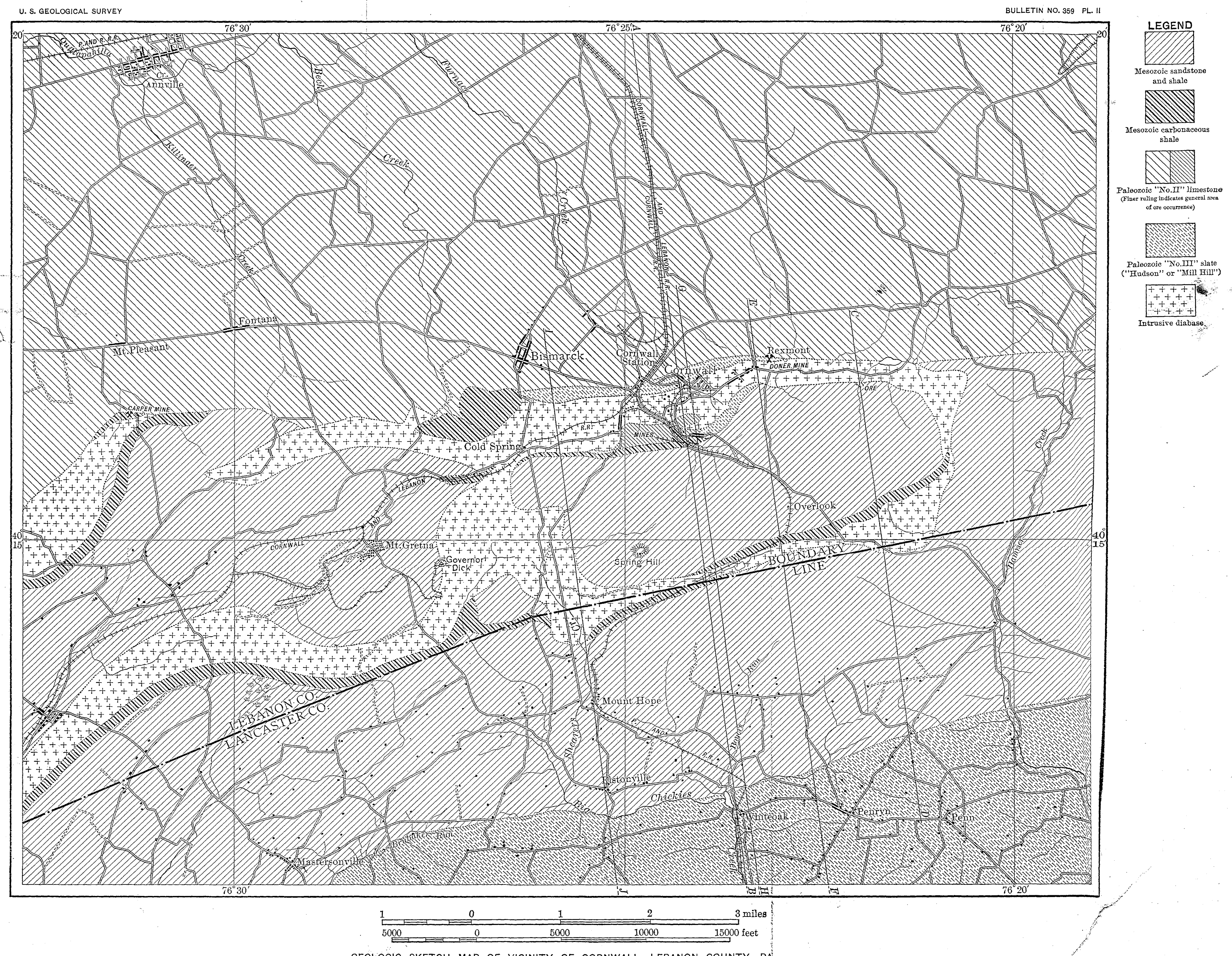


DIABASE INTRUSIONS.

The diabase next to the Cornwall deposit is an intrusive mass of considerable size and of complex shape. Along the north slope of the hills that face the Lebanon Valley its outcrop forms a continuous east-west band from a third- to a half mile in width and 9 miles in length. This body is connected by two southward-trending arms with a second band, which lies about 2 miles farther south and extends with a west-southwest course across the Susquehanna into York County. This southern mass of diabase has the form of a sill which follows a group of carbonaceous shales showing generally northward dips. Shales of the same group may be traced along the edges of the connecting arms both east and west of the Cornwall mines, and though local crosscutting may be noted, it is evident from the field relations that these surface connections are merely portions of the extensive sill that have been uncovered by erosion. On the other hand, the diabase of the northern band is a crosscutting mass, for it is bounded on the extreme west by massive sandstones of the Mesozoic; then by the same rocks on the south and by Paleozoic limestones on the north; next, just south of Bismarck, by black Mesozoic shales on both sides; farther east by these shales and blue conglomerate on the south and by the slates which form Mill Ridge on the north; at the mines by the limestones impregnated with ore and the slates of Mill Ridge; east of the mines as far as Rexmont by these slates on both sides; and thence, to a point beyond the Lebanon waterworks main reservoir, by Paleozoic limestones on the north and by Mesozoic strata on the south, except where small outcrops of slate and limestone just south of the dike have been revealed by two of the three streams that supply. the waterworks. (Through an error only two of these streams appear on the sketch map, Pl. II.)

From the conclusions that the southern diabase band is the cropping of a sill and that the northern band is a dike, it is but a natural step to regard the latter as having been the feeder of the former; and the warrantable belief that this is the actual relation forms the basis of the structure represented in the cross sections (Pl. III). That there is a connection between the dike and sill in the vicinity of the mines is indicated by the reported presence of diabase beneath the ore-bearing strata in all the diamond-drill holes that have been bored south and southwest of the present workings. It is hardly to be doubted that the sill formis a continuous sheet beneath the oblong area about 6 square miles in extent, which is surrounded by an unbroken outcrop of the diabase. 
STRUCTURE OF THE BEDS.

Within this area, rimmed by diabase, the observed dips are toward the north, and the average inclination of the strata has been taken by Lesley and D'Invilliers ${ }^{a}$ to be between $12^{\circ}$ and $15^{\circ}$. If, however, the diabase mass be accepted as a sill following the group of carbonaceous beds, it is evident from the distribution of these shales that in that part of the area lying west of the Cornwall Railroad the effective dip toward the north must be much less than $12^{\circ}$, because the shales outcrop on the south side at elevations between 700 and 800 feet, and just south of the mines their croppings are barely 100 feet lower. East of the railroad the strata may be somewhat more steeply inclined, as higher and higher horizons of the Mesozoic strata come into contact either with the diabase dike or with the slates which adjoin it for nearly 2 miles eastward from Miners village. In this direction it seems that the carbonaceous shales are overlapped by higher beds of sandstone and red shales, so that their contact with the Paleozoic rocks may lie well back from the edge of the diabase dike and some distance below the lowest Mesozoic strata locally exposed by the stream cuttings.

In Lancaster County (Pls. II and III), beyond the southern edge of the sill, lower and lower Mesozoic strata emerge, with east-northeast strikes and constantly increasing northward dips, until the boundary with underlying slates is encountered about 2 miles south of Penryn. The basal contact on this side of the Mesozoic belt is a nearly straight line, trending slightly south of west, extending from Hopeland past Brickerville to the bend of Chickies Creek, just north of Whiteoak station, and thence nearly to Mastersonville, where it takes a more southerly course, reaching Susquehanna River at Bainbridge. Near this southern boundary the dips of the Mesozoic strata are steep and locally are even overturned. Allowing for the observed gradually decreasing inclination toward the north, we have an estimated thickness of strata amounting to about 6,500 feet between the bottom of the Mesozoic and the group of carbonaceous shales in which the intrusive sill occurs; yet near the Cornwall mines, barely $1 \frac{1}{2}$ miles north of the point where the shales outcrop, and south of Bismarck, about 2 miles distant, the same beds are seen to have been deposited directly upon the Paleozoic rocks. This striking relation and its proper interpretation have an evident bearing on the correct understanding of the structural features of the Cornwall deposit, and consequently on any attempt to determine the possibility of the existence of other similar deposits in the neighborhood. The explanation suggested is that the Mesozoic beds were laid down under such circumstances that successively higher strata were spread

${ }^{a}$ Cornwall iron-ore mines : Ann. Rept. Geol. Survey Pennsylvania for 18s5, 1886. 


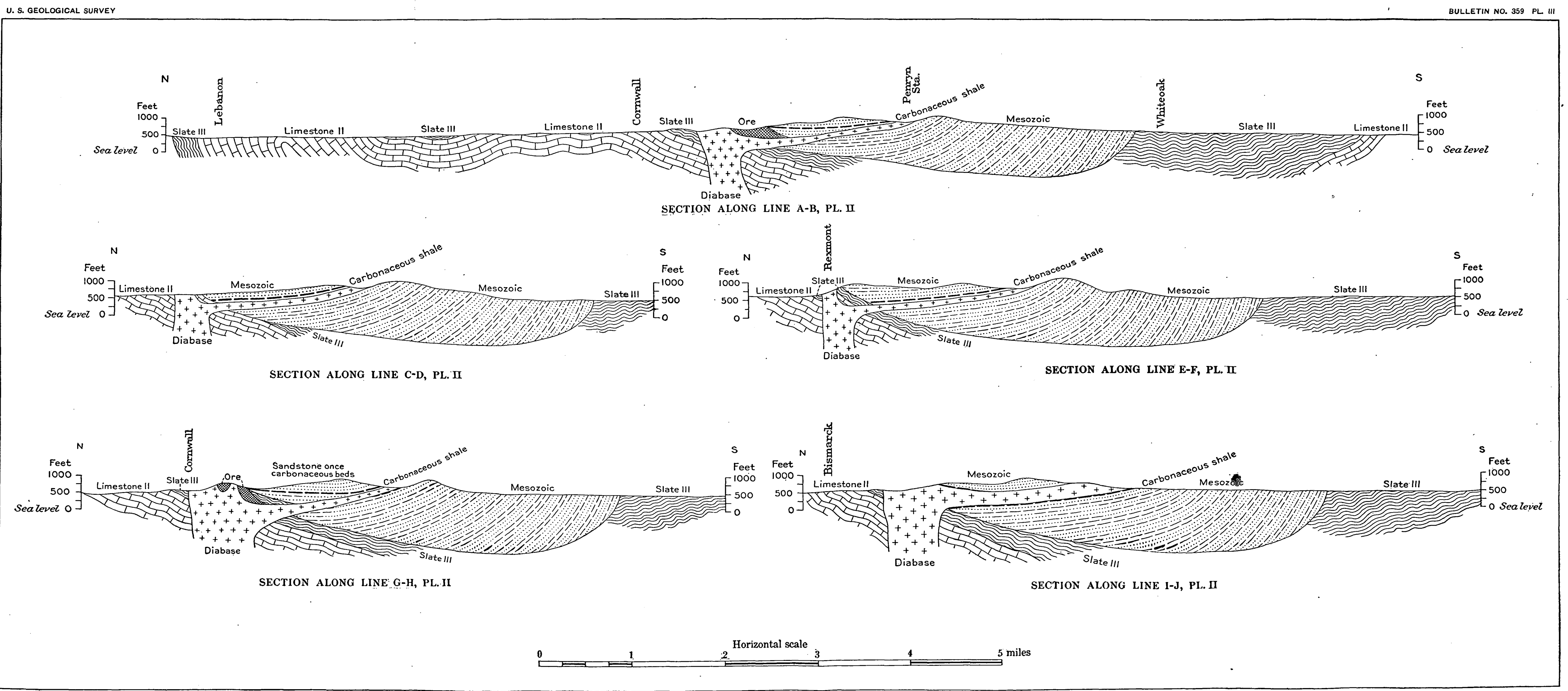

StRUCTURE SECTIONS IN VICINITY OF CORNWALL, LEBANON COUNTY, PA. 


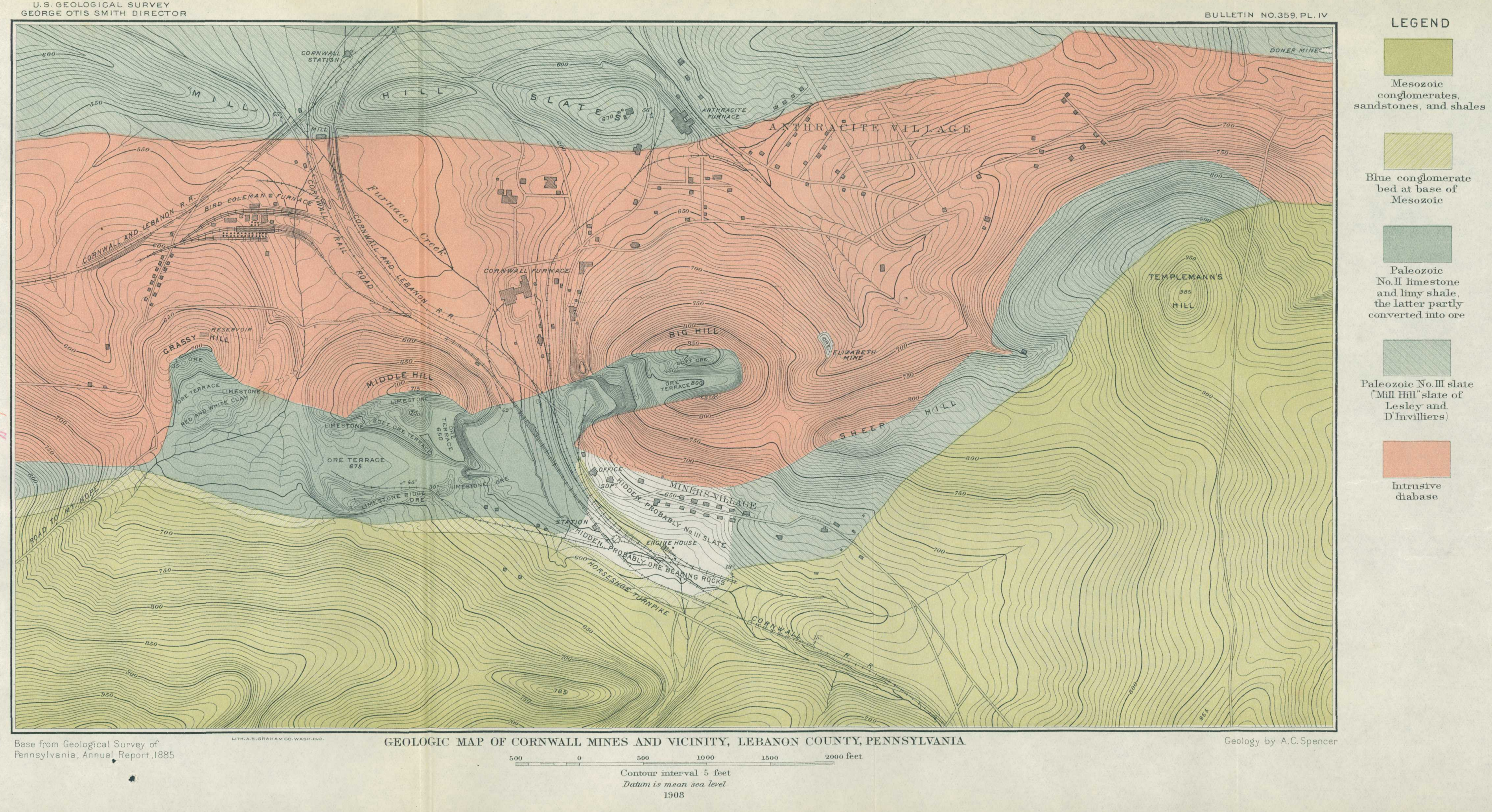


farther and farther toward the north against a continually receding shore. In other words, the facts observed indicate that the Mesozoic basin was sinking and widening as deposition went on, so that from south to north there is a marked overlap of the Mesozoic strata upon the Paleozoic basement. On the assumption that to this overlap is due the disappearance of the lower strata toward the north, a structure section from Lebanon to Whiteoak station has been drawn to show the general relations of the rocks (Pl. III). The north end of the section as far as Mill Ridge has been copied from the report of Lesley and D'Invilliers. ${ }^{a}$ It is to be observed that inasmuch as nothing is known concerning the width of the dike below ground or the attitude of its walls in depth the representation of these features on the section is entirely conjectural; also that in showing the Paleozoic limestone and slate beneath the Mesozoic rocks the intention is merely to suggest that they form a basement upon which the younger strata were deposited, and not to present even a guess concerning the structure or distribution of these formations underground.

\section{EXTENT OF THE DEPOSITS.}

General statement.-Attention may now be directed to the manner in which the Cornwall deposits embody all the favorable conditions listed on page 16. They occur next to a considerable body of diabase, which exhibits crosscutting relations to the stratified rocks adjacent. They are confined to limestone strata cut by this diabase, and these beds of the limestone are capped both by Paleozoic slates and by Mesozoic carbonaceous shales. Metamorphism of the sort which has affected the limy strata is almost lacking in both of these cap rocks; and though they are baked in the near vicinity of the diabase, the conclusion seems to be justified that they were not permeated by the mineralizing waters to the same extent that the limestones were. It seems a fair assumption that these rocks were from their nature relatively impervious to the solutions which formed the ore, and that they served in a very important degree to prevent the dispersion of these waters and to confine their movements and effects to the limestones and limy shales beneath them, a great body of which had been caught up in the angle between the crosscutting dike on the north and the sill extending out toward the south. There is every reason to believe that the great magnetite deposit at the Cornwall mines was formerly capped entirely over by beds of sandstone and shale, and that the appearance of the ore body at the surface is due to rather modern erosion. If so, two questions which naturally present themselves are: (1) What part of this deposit is still buried beneath barren rock?

a Cornwall iron-ore mines : Ann. Rept. Geol. Survey Pennsylvania for 1885, 1886, p. 526 . 
(2) Is it not probable that at other localities in the vicinity there are like deposits which, though not uncovered by natural processes, may be found by exploration?

The Cornwall ore body.-Diamond drilling now (1906) in progress will, if systematically continued, eventually delimit the Cornwall ore body. From a geologic point of view the strata which carry the ore may be expected to run out under the Mesozoic cover toward the south in the form of a wedge, the thin edge of which will be encountered where the sill of diabase, rising toward the south, reaches the unconformable surface between the ore-bearing strata and the overlying carbonaceous shales (Pl. III). That magnetite should continue to form so large a proportion of the rock in this direction as it does near the crosscutting dike seems improbable from the theory which has been stated concerning the origin of the ores.

Just west of the Grassy Hill mine the diabase is seen on the surface to trend directly across the strike of the ore-bearing strata and to come into contact with the overlying slate, which is exposed on the north slope of the little knoll west of the Mount Hope wagon road. It seems possible that the limy beds which elsewhere carry the ores may be present beneath this patch of slate, but farther west, where the carbonaceous shales appear in contact with the diabase, the sill seems to be entering this group of beds, so that in this vicinity there is no place south of the dike for the limestone beds to be present. except beneath the sill. Starting from a point about 1,000 feet west of the Mount Hope wagon road, where the carbonaceous shale overlaps the slate and comes into contact with the diabase, an irregular line drawn to the southern edge of the ore-bearing strata, when the position of this edge is determined by the drill, will indicate the general limit of these strata south and southwest of Grassy Hill.

East of the railroad and south of the diabase hook which forms the south side of Big Hill, the ore-bearing strata should be present just beneath the rather thick cover of surface débris. Slates appear on the hill slopes north of the eastern part of Miners village, and as these beds are known to lie stratigraphically above the limy beds, the latter are probably in contact with the diabase dike at a moderate depth beneath the capping of slate.

The slates continue as a narrow band from Miners village to the Rexmont-Overlook road. The presence or absence of the uppermost strata of the valley limestone immediately beneath the slate, and, if present, the thickness of the mass, are dependent on the local existence of a direct connection between the dike and the sill and on the depth at which they join. It is evident that if a connection between the sill and the dike exists just beneath the slate there can be no limestone above the sill, and that the deeper the connection the 
thicker will be the mass of limestone caught in between the dike and the sill. However far the limestone strata may extend along the southern wall of the dike, which trends northeastward from Miners village, just so far are the structural relationships between the different sorts of rock similar to those which have favored the deposition of ore at the Cornwall mines. All of this ground, as far as the roadl leading from Rexmont to @verlook, is regarded as likely to contain a continuation of the Cornwall ore bed and to warrant such expenditure as would be required to prospect it adequately. (See Rexmont-Overlook section, Pl. III.)

To summarize, it seems that exploration should be extended along the strike of the deposit for about 1,000 feet toward the west and for at least 5,000 feet toward the east.

Near-by deposits.-In regard to the possibility that similar deposits may occur in other localities, it may be said that from the geologic point of view they may very well exist in several places.

East of the Rexmont-Overlook wagon road the southern edge of the Cornwall diabase dike exhibits a crosscutting contact with the Mesozoic beds as far as the first of the three creeks which aftord Lebanon's water supply. Here outcrops of slate on the western bank of the stream and next to the diabase presumably correspond with the slate occurring in Mill Ridge and on the opposite or south side of the dike in the neighborhood of the Cornwall mines. On the ridge above this outcrop Mesozoic rocks are found, and the surface of overlap or unconformity lies somewhere between.

The next ravine to the east has been dammed to form a collecting reservoir, along the shores of which flat-lying strata of shale and limestone are well exposed. During the construction a mass of magnetite, which, though it proved to be a pocket, is said to have furnished 500 tons of ore, was encountered in an excavation on the east side of the creek below the dam. . From what may be seen at present, it is evident that this pocket of ore occurred between the wall of the diabase dike and limy strata lying just under the overlapping Mesozoic beds. All the sedimentary rocks are considerably metamorphosed, silicate minerals and small segregation of specular hematite being largely developed in the Mesozoic strata for several hundred feet to the south.

Several years ago the Lackawanna Iron and Steel Company put down three test holes in this vicinity, hoping to develop a workable deposit of magnetite. Hole No. 1 was situated a short distance north of the excavation referred to above, No. 1a about 125 feet farther north, and No. 2 on the ridge about 300 feet east of the excavation and about 120 feet above the creek. The following records of these holes have been furnished by the company: 
Records of drill holes near collecting reservoir.

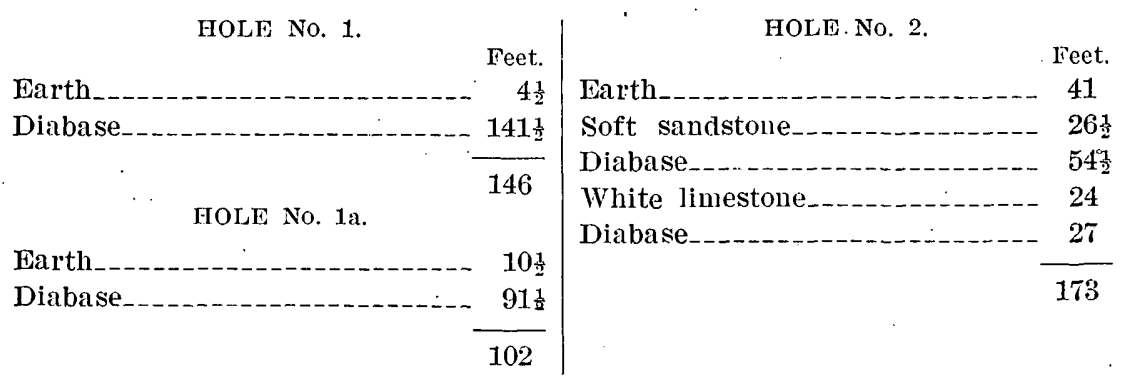

The configuration of the surface is such that hole No. 2, though 173 feet deep, penetrated only 51 feet below the level of the stream. Two interpretations may be placed on the section determined by hole No. 2-that the two bodies of diabase are wedges from the main dike extending out into the stratified rocks, or that there is here merely a waving contact between the dike and the stratified rocks penetrated by it. A hole situated 100 feet or more farther south might be expected to encounter a greater thickness of Paleozoic limestone, and there is the possibility that certain layers might be impregnated with magnetite. On the whole, in spite of the unfavorable result of the tests mentioned above, it seems that it may yet be worth while to make further explorations along the south side of the Cornwall dike from the reservoir westward to the Rexmont-Overlook road, and, as already suggested, thence to Miners village. In all probability a bore hole situated 100 or 200 feet south of hole No. 2 on the ridge above the reservoir would penetrate a considerable thickness of Paleozoic limestone beneath the overlapping Mesozoic beds, and there is no obvious reason why certain layers of the limestone may not be replaced by magnetite.

Eastward from the reservoir, where the pocket of ore was found, the limestone lying beneath the Mesozoic beds can not extend far before being cut by the dike, which within a short distance turns southward into the Mesozoic area and changes from a strongly crosscutting dike to a sill following the-bedding of the Mesozoic rocks.

In all probability a bore hole or shaft less than 50 feet deep located above the diabase in the ravine southeast of Rexmont would reveal slate or limestone, either one of which if present would warrant deeper exploration, even if no ore were discovered in the uppermost layers of the limestone. A fact which would seem to mark this as a promising place for prospecting is the occurrence of ore on the opposite side of the diabase dike at the old Doner mine northeast of Rexmont.

The southern border of the Cornwall diabase dike westward from its junction with the sill southwest of Cold Spring crossing shows a 
strongly crosscutting contact with massive Mesozoic sandstones. Between this contact and the outcrop of the diabase sill to the south no detailed observations have been made, so that little definite information concerning the structure of the area of Mesozoic rocks lying north and south from the Cornwall and Lebanon Railroad is at hand. However, red sandstone beds exposed near the railroad crossing onehalf mile northeast of Mount Gretna station show a dip of about $25^{\circ} \mathrm{N}$., and the contour of the west edge of the sill between the mountain known as Governor Dick and the railroad west of Cold Spring crossing likewise indicates a strong inclination of the strata in a northerly direction. Furthermore, only northerly dips are observed south of the railroad along the outcrop of the sill, and it is fairly assumable that the whole block between the two bands of diabase is rather strongly tilted in this direction. If this is accepted as a fact, the group of carbonaceous shales would nowhere meet the crosscutting dike less than 100 feet below the contact line as seen on the surface, except within a few hundred feet from the point where the southern edge of the dike crosses the wagon road west of Cold Spring. As the sill is known to lie in the carbonaceous shales for a long distance westward from the headwaters of Chickies Creek, and also, as it follows these strata both east and west to Cold Spring crossing, it seems most likely that it continues to occupy this position beneath the Mount Gretna block all the way from the southern outcrop to its buried junction with the feeding dike. This probability points to the failure of explorations which might be undertaken between the Cornwall-Colebrook road and the diabase dike, with the expectation of locating limestone strata in contact with the diabase dike, unless the search be extended beneath the sill of diabase.

Along its northern edge the diabase dike is bounded in different parts of its course by four distinct sets of strata. On the extreme west its northern wall is formed by Mesozoic sandstones for a distance of $1 \frac{1}{4}$ miles to a point a short distance west of the wagon road leading from the Horseshoe pike to Mount Gretna (Pl. II). From this place to the next north-south road the bounding rock is evidently limestone, though the line of contact is completely obscured by a cover of surface débris. The boundary has been represented on the map by a random line, the accuracy of which might possibly be improved by more detailed examination than has as yet been made in this vicinity. On general principles this contact may be included among favorable situations for the occurrence of iron ore, though but little emphasis is placed on the suggestion in view of the very slight study which has been given to the locality. Should the surface wash prove to be as deep as it seems to be at first glance, failure to have discovered float ore in tilling the fields can not be regarded as a strong argument against the possibility of ore masses being present in the 
limestone near the wall of the intrusive dike. The only one of the five features favorable to ore segregation mentioned on page 16 which seems lacking in this. vicinity is an impermeable cap rock over the strata lying adjacent to the diabase. At the same time the limestones do not include the strata immediately beneath the slates which comprise the ore-bearing beds at Cornwall.

Farther east there is an extensive patch of carbonaceous shale between the valley limestone and the diabase. Being identical in appearance with the Mesozoic black shales in the railroad cutting on the south side of the dike, within the narrow angle between the dike and the sill, these beds are supposed to belong to the same horizc... They lie nearly horizontal, and are supposed to rest directly upon the limestone or possibly in part upon slate, as do similar beds just south of the ore banks. Every geologic consideration points to this as good prospecting ground. It may be that slates (corresponding to those which outcrop in the wagon road one-half mile southwest of Bismarck) lie between the carbonaceous shale and the limestones in the vicinity of the diabase contact, but somewhere at no great depth beds of limestone belonging to the same horizons as those which have been converted into ore at the Cornwall mines must come into contact with the intrusive diabase. Capped as these beds are by strata only slightly permeable by circulating waters, the conditions would seem to be very similar to those which led to the production of the Cornwall deposit. If the boundary between the shales and the diabase can be taken to indicate the general shape of the northern wall of the dike, there is here an embayment from the north resembling in a way the one from the south, which is occupied by the Cornwall deposit.

From the Bismarck-Mount Hope road to Rexmont the Cornwal! diabase dike is bounded on the north by slates, which occupy a band 300 to 400 feet wide along a line of hills known as Mill Ridge. These slates were assigned by Lesley and D'Invilliers to "Formation No. III " of the Pennsylvania Paleozoic section, and they were regarded as resting conformably upon the limestones of "No. II," with a generally rather low dip toward the south. These suggestions seem entirely correct, and it is concluded that as far as these slates extend east and west along the north side of the diabase dike the uppermost beds of the valley limestone, or " Formation No. II," must come into contact with the diabase at a very moderate depth and offer a favorable condition for the existence of iron ore. Though this suggestion is made entirely on the basis of the principles set down on page 16, it finds strong corroboration in the fact that ore occurs just beyond the eastern outcrops of the slate at the old Doner mine. The strata in which the ore occurs at this point are evidently to be included among the uppermost layers of the valley limestone, and their contact with 
diabase, though hidden by surface wash, can not be far distant from the mine. It is believed that the geologic features of the Doner mine are essentially those which exist beneath the surface for more than 2 miles westward from Rexmont, and there is every indication that the rocks are identical in stratigraphic position with those which contain the great deposit of ore in the Cornwall mines. Separated from the mines only by the dike of diabase held to be responsible for the segregation of iron in the deposits already known and worked, this ground would seem worthy of systematic exploration.

From the north-south road leading to Rexmont as far eastward as Horst's mill, deep wash derived from the near-by hills completely hides the northern edge of the diabase dike, and it is only at the Doner mine that rocks near the contact are exposed at all, and even here nothing definite can be made out regarding the attitude of the strata. The mine is said to have furnished 5,000 tons of ore similar in every way to the surface ore at the Cornwall banks but occurring intermixed with loose sand. The pit from which the ore was mined is now completely caved in, but seems to have been 40 or 50 feet wide and perhaps 250 feet long. North of the workings bowlders of hard magnetite are found in the soil over an area 700 to 800 feet square. This material is supposed to be float from the Doner deposit. Several years ago two or three holes were drilled on this property, but beyond the report that no attractive ore body was encountered records of this work have not been procured. From the fact that the old workings extended east and west, three possibilities may be considered as to the shape of the ore mass in its original state, before it became broken down by surficial weathering, and it is believed that negative results at this place are not to be considered as finally adverse to the presence of a workable ore body until tests have been carried out with reference to each of these possibilities: (1) The impregnated rock may have been a layer in the limestone capped over by a barren stratum. If, then, the beds have a southward dip the edge of the diabase may lie some distance to the south; $(2)$ the ore may have formed along the wall of the dike as a replacement of a limited amount of limestone in contact with the intrusive rock; in this case the diabase would be found very near the old workings; (3) the ore may have been deposited along the walls of a fissure running parallel with the wall of the dike, but at some distance from it. The deposit of ore at the old Carper mine, 8 miles west of Cornwall, seems to have had this origin.

The contact of diabase with the valley limestone eastward from the Doner property to the main reservoir of the Lebanon waterworks is hidden by a heavy apron of sandstone débris, so that the line representing the boundary on the sketch map is only an approximation. Though ore may occur along this contact, prospecting would 
hardly be taken up unless favorable results had been obtained in some of the more accessible localities suggested above.

\section{MINES WEST OF CORNWALL.}

Near the edge of the Mesozoic belt between Cornwall and Susquehanna River there are two minor occurrences of magnetic ore-one at the old Carper mine in Lebanon County, about 1 mile southeast of Mount Pleasant, the other in Dauphin County, about 2 miles southeast of Hummelstown.

\section{CARPER DEPOSIT.}

The Carper deposit, from which 1,500 tons of ore have been mined, appears to lie in a fault break, which may be regarded as a westward extension of the fissure which holds the Cornwall diabase dike. North of the ore pit the rocks are Paleozoic limestone, while to the south are baked shales, followed by diabase. The shales were regarded by Lesley and D'Invilliers as equivalent to the slates of Mill Ridge occurring at Cornwall, ${ }^{a}$ but to the writer they seem to belong with the Mesozoic strata.

The diabase which outcrops south of the mine is a sill which follows the Mesozoic strata: The sill strikes northeast and southwest, and dips toward the northwest. The trend of the diabase is diagonal to the course of the fault, and the intrusive rock does not continue north of the break. On the geologic map (Pl. II) it has been represented as ending at the fault, though exposures are not sufficient to show that it actually extends as far toward the northeast. Toward the southwest the diabase widens in outcrop and is known to constitute a large mass. The sandstones and shales near it are strongly baked or indurated, and are also bleached to a considerable extent. The occurrence of the ore in the fault fissure, the presence of the igneous rock near by, and the fact that the inclination of the diabase mass toward the north and northwest would carry it beneath the place where the ore outcrops make it probable that the deposit was formed by solutions circulating along the fault break and impelled by the heat of the buried diabase. If the true relations of the deposit are as here suggested, the ore should persist in depth and should also occur at other points along the fault both east and west of the old mine. Though the exact position of the fault is hidden by overwashed débris from the adjacent hills, no serious difficulty would be experienced in finding it by means of excavations. This fault appears to be the westward extension of the fissure occupied by the crosscutting mass of diabase at Cornwall.

Iron ore is reported to occur about 1 mile southwest of Mount Pleasant, where some prospecting was done several years ago. This 
locality was not found, and it is not known that the ore is of the Cornwall type. In this neighborhood the Paleozoic limestones contain several masses of intrusive diabase, so that it would not be at all surprising to find ore like that of the Cornwall mine.

HUMMELSTOWN DEPOSITS.

The deposits 2 miles southeast of Hummelstown are situated well within the belt of Mesozoic rocks on the east side of Waitonville Brook. The ore, consisting of magnetite and specular hematite somewhat contaminated by pyrite, occurs in pockets, several of which have been worked out, but from what may be seen the deposits could hardly have been of any great importance. A small amount of garnet occurs with the ore minerals. The old workings are in the valley of a small stream and extend in a general east-west direction for a distance of about 2,500 feet. Except along the wagon road there are few exposures of rock in place in the vicinity. North of the ravine in which the ore pits are situated the strata stand in nearly vertical position, but south of the ravine the beds of sandstone have a northerly dip of about $20^{\circ}$. From these observations it is evident that the deposits occur adjacent to and probably in part along a strong fault break. Everywhere in the vicinity of the fault.the sandstones are greatly bleached and indurated, as similar rocks are elsewhere in the neighborhood of diabase masses, and, though no outcrops of the igneous rock appear in the immediate vicinity, it is believed that diabase must be present at some unknown depth beneath the surface and that waters heated by this rock, or perhaps derived from it, were responsible for the general metamorphism and for the segregation of the iron ores.

Though the deposits are of interest to the student of ore genesis, it does not seem that they offer sufficient encouragement for more extensive exploration.

\section{BERKS COUNTY DEPOSITS.}

\section{WHEATFIELD GROUP.}

GENERAL DESCRIPTION.

The Wheatfield group of mines, with which the Ruth mine is here included, is situated about 7 miles southwest of Reading and a short distance southeast of Fritztown station, on the Columbia division of the Philadelphia and Reading Railroad. (See Pl. VI.) In their geologic features the deposits of iron ore at this place show certain striking resemblances to the Cornwall deposits 20 miles to the west. The ores occur as irregular masses, having a general layer-like form, 
interbedded with limestone strata, but the ore bodies are numerous rather than large, and lack of persistency is a marked characteristic. In respect to stratigraphic position, the strata which carry the deposits do not correspond with those of the Cornwall mine, for they apparently belong at the base of the Paleozoic limestones ("No. II" of the Second Pennsylvania Survey), as at the Raudenbusch and Island mines near Reading and at Boyertown. This conclusion regarding the equivalence of these strata is not based on a critical study of the question by the present writer, but is deduced from recorded descriptions by D'Invilliers and from the distribution of the Paleozoic formations as exhibited on his geologic map of Berks County. ${ }^{a}$

Like the deposits at Cornwall, Reading, and Boyertown and at the Jones mine, the Wheatfield deposits occur very near the overlap of Mesozoic beds and adjacent to a large intrusion of diabase.

\section{DIABASE INTRUSION.}

The ore-bearing strata, appear at the surface along the east and north sides of a roughly rectangular area of sedimentary rocks, forming a northward,embayment in the principal diabase mass of the district. The greater part of this area, which is nearly a mile long and three-fourths of a mile wide, is covered by Mesozoic rocks. The older strata, in which the ore occurs, are restricted to a band 150 to 250 yards wide next to the curving edge of the diabase intrusion. The south edge of this band is formed by the overlap of the Mesozoic beds, south of which there is an outlying, irregularly shaped mass of diabase opposite the embayment in the main intrusion. (See Pls. $\mathrm{V}$ and VI.)

The mass of diabase that curves around the Wheatfield group of mines constitutes the western termination of an intrusion which extends 7 miles eastward to Schuylkill River and thence somewhat more than 10 miles in a southeasterly direction along the western side of the broad Schuylkill Valley (Pl. V). The outcrop of this diabase is from one-third mile to 1 mile wide. Throughout the greater part of its course it lies wholly within the Mesozoic area, where it has the form of a sill, closely following the stratification of the incasing rocks. Near the Schuylkill, however, where its course changes from east to southeast, and also near the Wheatfield mines, marked crosscutting may be observed, and Paleozoic as well as Mesozoic rocks come into contact with the diabase. It is in these Paleozoic strata near the diabase that the ore deposits occur at the Fritz Island and Raudenbusch mines south of Reading, and at the Wheatfield mines 7 miles farther east. (See cross sections, figs. 1, 2, and 3.)

a Geology of the South Mountain belt of Berks County: Second Geol. Survey Pennsylvania, Rept. D3, pt. 1, atlas, 1883. 


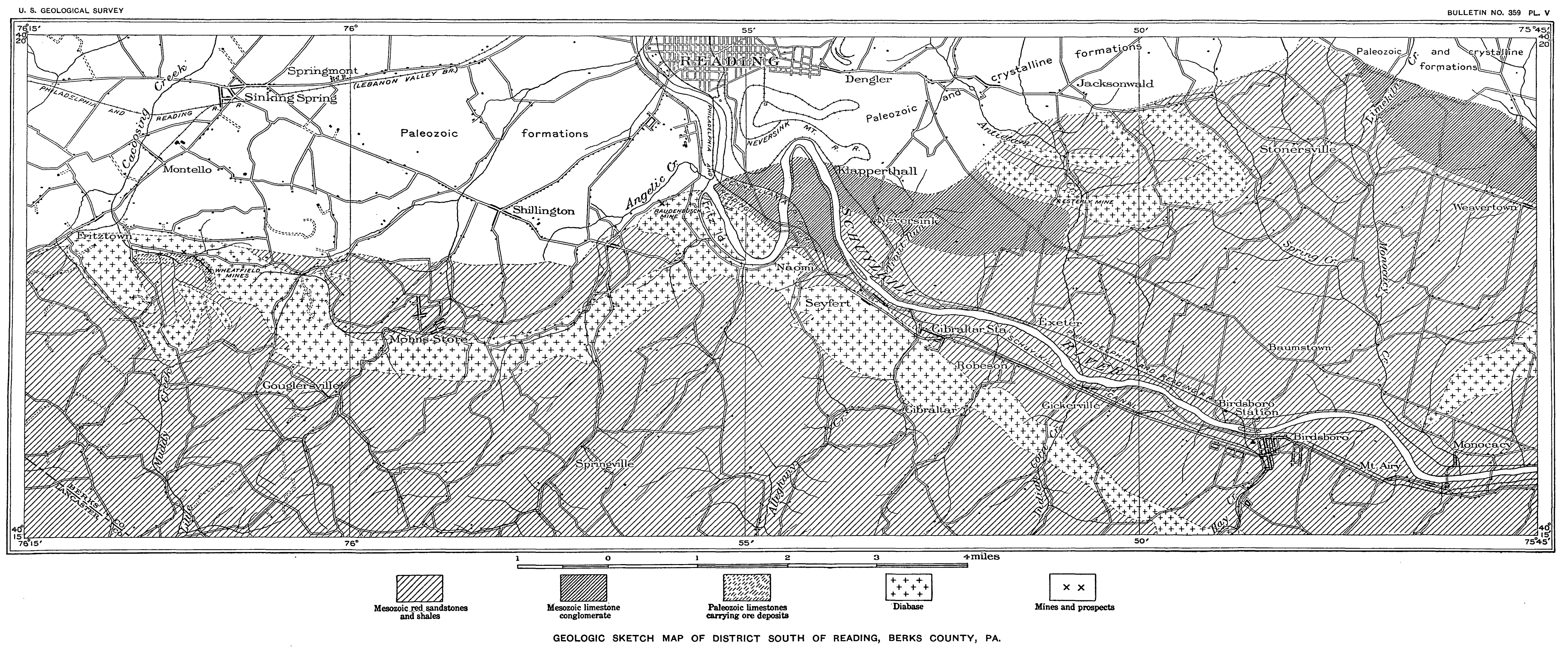


The Wheatfield mines have not been extensively worked for more than twenty years, though small amounts of surface ore have been extracted from time to time, the last mining having been done in 1905 and 1906. The ore to a depth of 30 or 40 feet is reported to be invariably soft or earthy, evidently as a result of the ready decomposition of the original ore, owing to the presence of considerable pyrite. These soft ores have been desired by ironmasters for mixtures, but the unweathered or hard ores seem to have found little favor, as they are at once of rather low iron content and so high in sulphur as to require roasting before they can be used in a blast furnace. Apparently for this reason, and because the deposits are not large or even persistent, these mines have not been more systematically developed.

STRUCTURE OF THE ROCKS.

Most of the old workings of the group are situated near the east side of the area of sedimentary rocks which sets back from the south

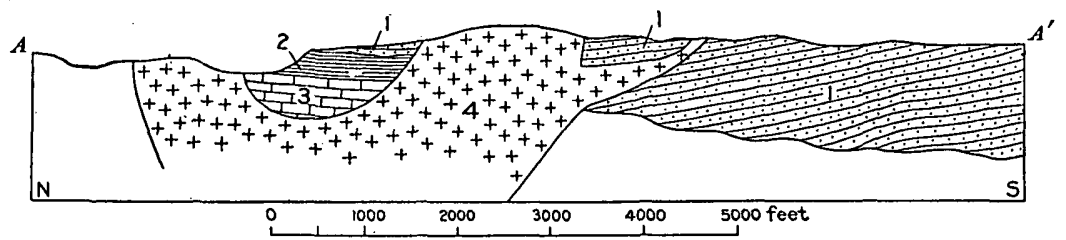

FIG. 1.-North-south structure section 400 feet east of Ruth mine, Wheatfield group (along line $A-A^{\prime}$, Pl. VI). 1, Mesozoic beds ; 2, Paleozoic slate; 3, Paleozoic limestone; 4 , diabase intrusion.

into the diabase dike and south of the east-west public road which follows the upper valley of Cacoosing Creek. About a dozen open pits have been operated at various times, and in addition many slopes and several vertical shafts. Across the creek, on the north side of the wagon road, there is an opening, formerly known as slope No. 1, and in 1905 some surface ore was taken out by means of a slope located a short distance east of these old workings. The Ruth mine is situated about one-half mile west of slope No. 1, about 200 yards east of the direct road from Fritztown to Adamstown.

In the more sontherly Wheatfield workings the strikes of the strata run nearly north and south, as shown both by the direction in which the pit workings extend and by the beds of limestone exposed in the old excavations; but farther and farther north the strata turn more and more toward the northwest and finally run nearly east and west at slope No. 1. Dips are here invariably toward the concave edge of the curving band of ore-bearing rocks and away from the wall of the surrounding diabase. At the Ruth mine, where the strata are 
fairly well exposed in the open cut, the stratification is found to be nearly horizontal, though the ore body is reported to dip $30^{\circ} \mathrm{S}$, indicating that it is not conformable to the bedding of the inclosing rocks. Both here and at slope No. 1 the foot wall of the ore is diabase and the immediate hanging wall is limestone or limestone breccia. In both places also the limestone capping above the ore is overlain by slate, and in the hills south of the Ruth mine débris of this slate and a few shallow excavations show it to have a thickness of about 80 feet. At slope No. 1 its thickness can not be determined and the area which it covers can not be defined, owing to lack of exposures.

No stratum corresponding to the slate mentioned above has been encountered in the workings situated south of the public road, but the changing strike of the bedding toward the north along the ore band toward slope No. 1, together with the fact that the limestone layers in the Ruth mine, in slope No. 1, and in several of the southern workings are similarly composed of fragments, would make it appear that the strata occurring in the southward-trending leg of the

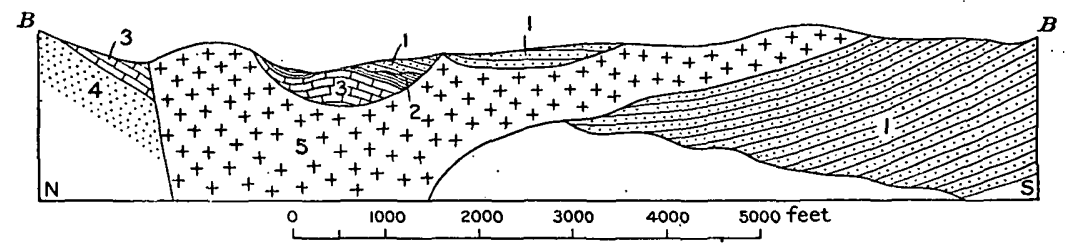

FrG. 2- North-south structure section near slope No. 1, Wheatfield group (along line $B-B^{\prime}$, Pl. VI). 1, Mesozoic beds ; 2, Paleozoic slate; 3 , laleozoic limestone ; 4 , Paleozoic quartzite; 5 , diabase intrusion.

strip in which the ore is found lie stratigraphically below the bed of slate. In this case, as the beds dip toward the west, it is possible that the slate may be present west of the main workings beneath the surface capping of the Mesozoic sandstones.

Two beds of limestone, one solid and the other made up of fragments, are exposed, with low southerly dips, in the creek bed between the two main tributaries from the south (Pl. VI): These strata are supposed to correspond with those in the main Wheatfield workings, and their presence in this place suggests that the slate at slope No. 1 can not be connected by continuous outcrop with the slate at the mine. The dips at the two places are not in accord, and it may very well be that there is a fault between.

In the bed of the more westerly of the two northward-flowing brooks (Pl. VI), 500 or 600 feet above its junction with the main creek, green clays containing disseminated crystals of magnetite are found. This material resembles some of the earthy. material from the mines, and with little doubt it represents the weathered crop of a stratum belonging to the set of beds which carries the ore deposits 


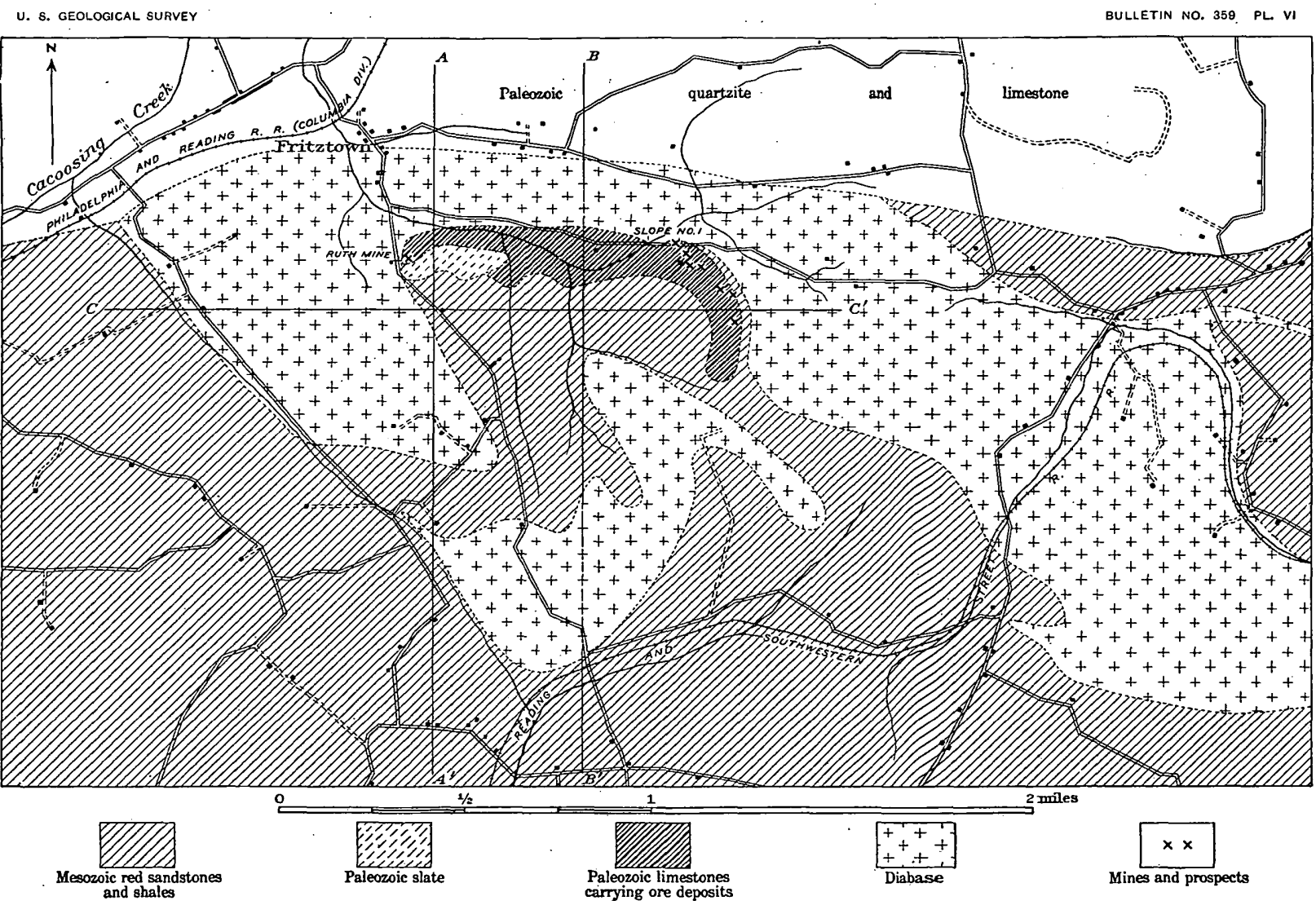

GEOLOGIC SKETCH MAP OF VICINITY OF WHEATFIELD MINES, BERKS COUNTY, PA. 
$1 \frac{1}{2}$ miles to the east. Appearances also favor the opinion that this horizon is nearly the same as that of the ore-bearing beds at slope No. 1 and at the Ruth mine. Outcrops of Mesozoic sandstone are seen on the east bank of the brook near by, and 1,000 feet or so upstream red shales and sandstones are present, striking N. $10^{\circ}$ E. and dipping $30^{\circ} \mathrm{W}$. In the bed of the eastern brook the strike is the same, but the dip is only $10^{\circ} \mathrm{W}$.

The attitude of the rocks in the several places mentioned above shows that there is a strong unconformity between the Mesozoic sandstone and the set of strata which carries the ores; this is also shown by the fact that in some places the younger beds rest directly upon the limestones, whereas in others, as on the knoll south of the Ruth mine, they were deposited upon the stratigraphically higher slate. This relation makes it ëvident that none of the rocks which incase the ore can belong to the Mesozoic, though the contrary was believed to be the case by Rogers, whose opinion was accepted by Willis, ${ }^{a}$ and by D'Invilliers ${ }^{b}$ at the time his report upon the geology of Berks County was written.

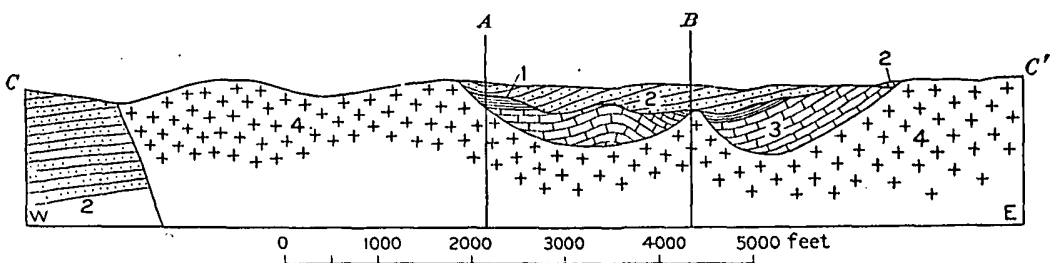

Fig. 3.-East-west structure section 1,000 feet south of public road, Wheatfeld group (along line $C-C^{\prime}$, Pl. VI). 1, Paleozoic slate; 2, Mesozoic beds; 3, Paleozoic limestone; 4 , diabase intrusion.

The rocks in the neighborhood of the Wheatfield group of mines are sufficiently exposed to reveal very. complicated geologic relations without being well enough shown to make possible the determination of these relations in detail. Information is lacking which might suggest the shape of the diabase intrusion underground or which might lead to an estimate regarding either the thickness of the calcareous beds which carry the ore deposits or the nature of the strata which lie below them. All these points must be known in at least a general way before geologic cross sections of any practical value can be drawn. The sedimentary rocks of the area which sets back into the main dike of diabase may be partly or entirely underlain by a mass of igneous rock forming a connection between the main crosscutting dike and the southerly body of diabase, or it may be that the surrounding masses of diabase approach each other only at rather

a Willis, Bailey, Tenth Census, rol. 15, p. 228.

${ }^{b}$ Second Geol. Survey Pennsylvania, Rept. D3, 1883.

54370-Bull. $359-0 \mathrm{~S}-3$ 
great depth. Whatever the actual relations may be, they can not be made out from features observed on the surface, and their determination must await information furnished by diamond-drill explorations.

Systematic study of the Paleozoic formations of the district might definitely fix the position of the Wheatfield ore-bearing strata with reference to the quartzite which occurs in the ridge just north of the diabase intrusion, and furnish a basis for estimating their thickness in the vicinity of the mines. These determinations would be, however, of small practical value compared with data which might be procured incidentally if a few well-located holes were drilled to test the downward extension of the ore-bearing strata and the degree to which they are mineralized in depth.

\section{PRACTICAL CONCLUSIONS.}

Though so much is indefinite or unknown regarding the geology of the Wheatfield deposits, yet the number and distribution of the ore beds already worked, the observable structure of the strata in which the deposits lie, and the general relations which they bear to the diabase mass and the overlying Mesozoic strata, when considered together, suggest that the expense of a certain amount of exploration in the northern half of the sedimentary embayment would be justified by the chances of locating important bodies of ore. As already stated, the impression gained from strikes and dips in the band of ore-bearing strata, and from the occurrence of the two patches of slate at the Ruth mine and slope No. 1, is that the strata which carry the ore beds in the southern group of mines lie stratigraphically below the slate. At the Ruth mine the slate and limestone beds lie nearly horizontal, and it seems that a hole drilled anywhere between this old opening and the first northward-flowing creek to the east must penetrate the whole set of ore-bearing beds unless part of them are cut out beneath by the intrusive diabase. The proximity of the diabase would lead to the expectation that beds suitable in composition for impregnation with iron minerals would be, in part, at least, converted to ore. Southward from the Ruth mine the limy strata are overlain at first by slate and finally by sandstone as well, but beneath perhaps 150 feet of this capping they doubtless come into contact with the cross-cutting mass of diabase which forms the bold hills west of the wagon road, and the vicinity of this contact is again favorable to the presence of ore.

It is probable that under the meadow which extends along the creek the set of ore-bearing strata would be encountered immediately beneath the valley wash, as indicated by the beds of limestone outcropping between the two northward-flowing tributaries. Furthermore, the southward dip of the diabase wall in slope No. 1 suggests that these strata will be found resting upon the inclined floor of the 
intrusive rock in a manner reproducing in a way one of the striking features of the Cornwall deposit.

From a practical standpoint deep prospecting in the vicinity of the main workings of the Wheatfield group would seem to offer somewhat better chances for a successful outcome than explorations elsewhere in the neighborhood, because the presence of ore in so many places reveals the fact that there has been a very important amount of mineralization. With reference to the theory that the ores of the Cornwall type have been produced by replacement of limy strata induced by the intrusive diabase, it is more than likely that the mineralizing solutions percolating through the rocks moved away from the hot diabase rather than toward it and at the same time tended mainly upward toward the surface rather than downward toward the source of heat.

This line of reasoning leads to the expectation that the ore bodies coming to the surface along the eastern leg of the band of Paleozoic strata may increase in number as well as in size and persistency as the ore-bearing strata are followed downward along their west and southwest dips.

The practical question whether hard iron ores of the grade thus far found in the unweathered portions of the Wheatfield deposits, if discovered in comparatively large amount, would be worth developing at the present time lies beyond the scope of the present investigation. The writer believes, however, that the fact that the owners have never attempted to determine the real possibilities of the property by systematic prospecting can not be taken as evidence that such exploration is not fully warranted as an undertaking likely to give adequate returns on the required outlay.

As already pointed out, the Wheatfield mines, as well as the Raudenbusch and Island mines, which lie about 7 miles to the east, are next to the same mass of intrusive diabase at the only localities where it comes into contact with the Paleozoic formations on the surface (Pls. $\mathrm{V}$ and VI). Throughout the interval the diabase has the form of a northward-dipping sill outcropping parallel with and from one-half to 1 mile south of the northern edge of the Mesozoic belt. Somewhere beneath the surface the sill must reach the Paleozoic rocks beneath the cover of Mesozoic shales and sandstones, and it seems very likely that here its form changes to that of a dike. If this be the case, conditions favorable for the occurrence of ore may exist along the walls of the dike wherever limy Paleozoic strata come into contact with it. Probably the most favorable condition would be realized if strata which correspond in stratigraphic position with those at the Wheatfield mines could be found next to the dike.

Though the broad suggestion that buried ore bodies may exist in the situation indicated seems entirely valid, the chances of locating 
deposits of value are regarded as too remote to be seriously considered from a practical standpoint. Prospecting along this strip of country north of the diabase sill is therefore not recommended except where the intrusion approaches the northern edge of the Mesozoic belt, and even here the possibilities can hardly be regarded as very encouraging.

For $2 \frac{1}{2}$ miles east of Fritztown station the diabase is in contact with Paleozoic rocks, but beyond the fact that the hills north of the diabase are composed of quartzite (in one place dipping $50^{\circ} \mathrm{S}$.), nothing concerning the local geology can be stated at the present time, because the country has not been examined in detail. If limestone beds are present above the quartzite, and if the general dip of the formations is toward the south, so as to carry them down beneath the diabase, the vicinity of the contact would seem to offer favorable conditions for the occurrence of ore masses like those which are present immediately opposite, on the south side of the dike.

\section{RAÚDENBUSCH MINE.}

Describing the Raudenbusch property in $1858, \mathrm{H}$. D. Rogers says: ${ }^{a}$

About half a mile west of the preceding [Island mine] is the Raudenbusch mine, which, we are informed, yields its proprietors at the Phoenixville furnaces 5,000 tons of ore per annum. The vein ranges a little north of east. Its foot wall is white metamorphic limestone, or marble, and its hanging wall or roof a dull sea-green, serpentine-like rock which on exposure soon crumbles down like ordinary shale. The vein, dipping $36^{\circ} \mathrm{S}$., is followed by a slope 280 feet beneath the surface. At the bottom gangways are driven 200 feet west and 400 feet east to a fault cutting out the vein. A higher level, 160 feet from the surface, is driven 300 feet east. The ore is now taken from this level. Like all others, this vein is exceedingly variable; while wholly or almost entirely absent in some places, in others it has been found 30 feet thick. Its average bulk will not exceed 12 feet. The gangue stone of the ore is a light-blue rotten limestone, from which the ore is scarcely distinguishable except by its greater weight and deeper tint. Of the entire ground wrought, about one-half of the material is sufficiently rich in iron for the furnace; the remaining rubbish is used as stopping in the old workings.

\section{D'Invilliers states : ${ }^{\natural}$}

There are two small shafts on the property, one of them 50 feet deep. On the dump are seen gray, greenish, and black limestones very much decomposed, some of which may represent the presence of the brecciated Mesozoic "all sorts" [i. e., limestone conglomerate] so characteristic of this part of the range, but none such is seen in place on the surface. $* * *$ Most of the limestones seem altered, which is accounted for by the proximity of the trap dike [diabase] to the south. This trap shows in the 50-foot shaft, as also some light-gray to white limestone, the latter showing a slight coating of hematite.

\footnotetext{
a Geology of Pennsylvania, vol. 2, 1859, pp. 716-717.

${ }^{v}$ Geology of Berks County: Second Geol. Survey of Pennsylvania, Rept. D3, 1883, pp. $342-343$.
} 
To the present writer it seems unlikely that any Mesozoic rocks, either limestone conglomerates, shales, or sandstones, are present north of the diabase in this vicinity. The only rock now to be seen at the surface is white limestone exposed in the farm road that gives access from the public road to the fields just north of the old mine. South of the wagon road, on the slope of the hill, a shaft not mentioned above was sunk through a green shaly rock, probably the same as that referred to by Rogers as forming the hanging wall of the ore. 'This material seems to be of sedimentary origin, atrd it evidently lies between the ore and associated limestone beds and the mass of diabase that forms the adjacent hill. The surface distribution of the diabase is shown on the sketch map (Pl. V), from which it may be seen that it is a northward offshoot from the intrusive sill described in the discussion of the Wheatfield mines. In relation to the Mesozoic strata, this northward-reaching arm is evidently crosscutting, though in respect to the Paleozoic strata it may be locally following the bedding, as is suggested by the southerly inclination of the old mine slope.

It seems a reasonable conclusion from what is known concerning the distribution of quartzite, slate, and limestone along the south edge of the Paleozoic area that the Raudenbusch deposit, like those of the Wheatfield group, lies in the beds of passage between the quartzite and the limestone. Crumpled slate is exposed in a little knoll about $1 \frac{1}{2}$ miles southwest of the mine and one-half mile west of the Center Hotel; just west of this knoll quartzite appears with dips toward the southeast beneath the slate. In the road-metal quarry along the wagon road on the east side of the slate knoll, Mesozoic conglomerate rests upon the slate, with its stratification dipping gently southward. Half a mile east of the mine southward-dipping quartzite forms the prominent hill south of the reservoirs above the wagon bridge over Angelic Creek. Immediately south of this quartzite knoll, slates and limestones may come in above the quartzite before the diabase is reached, but their presence or absence can not be determined because of the existing mantie of surface débris. It is suggested that other ore beds like the one formerly mined may exist along the northern wall of the diabase both east and west of the Raudenbusch mine. On the west the question could be readily settled by running crosscut tunnels toward the diabase and drifting either along the contact or, perhaps better, along the hanging wall of green slate, which will probably be encountered before the intrusive rock is reached.

Suggestions for prospecting eastward from the Raudenbusch mine will be deferred until after the Island mine has been described. 
FRITZ ISLAND AND VICINITY.

ISLAND MINE.

The Island mine is situated 2 miles south of Reading, at the north end of Fritz Island, in Schuylkill River. The old workings are very near the edge of the Mesozoic belt, and are thought to have penetrated the Paleozoic limestone which lies beneath the Mesozoic strata. Large masses of diabase are present in the vicinity and dikes of the same rock were encountered in the mines $(\mathrm{Pl}$. V). The geologic features of the mine may be summarized from the account by D'In-

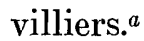

The ore was encountered through the washing away of some ground by high water during the winter of 1850-51. In opening the mines and extending the workings underground it was found that the ore occurs in a magnesian limestone, with associated shales of a sea-green color like those at the Raudenbusch mine, and that the ore-bearing strata are capped over by a limestone conglomerate.

Diabase is here and there the foot wall, but beneath the ore there is, more commonly, a decomposed sandstone, regarded as of Cambrian age, and therefore similar to the quartzite outcropping in the knoll about half a mile to the north. The ore pinches and swells, as in the Boyertown mines, the maximum recorded thickness being 22 feet. Horses or wedges of limestone are found with ore occurring on either side. The strike of the deposits is nearly east and west, and though the general dip seems to be toward the north, in places at an angle as great as $40^{\circ}$, locally the ore stands vertical or even dips toward the south. Slope No. 1, beginning on the outcrop, is 231 feet deep, being inclined at the top about $62^{\circ}$ and averaging about $46^{\circ}$. Three levels were run eastward from the slope, passing under the bed of the river and under a small island in the eastern channel, known as Yost Island. West of the shaft the two lower levels were carried about 150 feet, which brought them beneath the east end of the open pit (Pl. VII). The gangways are about 60 feet apart, the upper one being about 50 feet below the surface.

Considerable stoping was done above the lowest level. In the bottom of the mine, 125 feet east of the slope, the ore was found to branch and was followed by two drifts' which came together 175 feet beyond. Irregularity of dip is shown by the vertical attitude of the vein in the middle level 300 feet east of the slope. Diabase was encountered beneath the ore in all the drifts, and a crosscut from the bottom level revealed a leader of ore on the south side of this dike. The dike is somewhat more than 100 feet thick, and its south wall nearly vertical. The ore lying south of the dike dips to the south and is thought to be the same vein as that opened by slope No. 2 and 


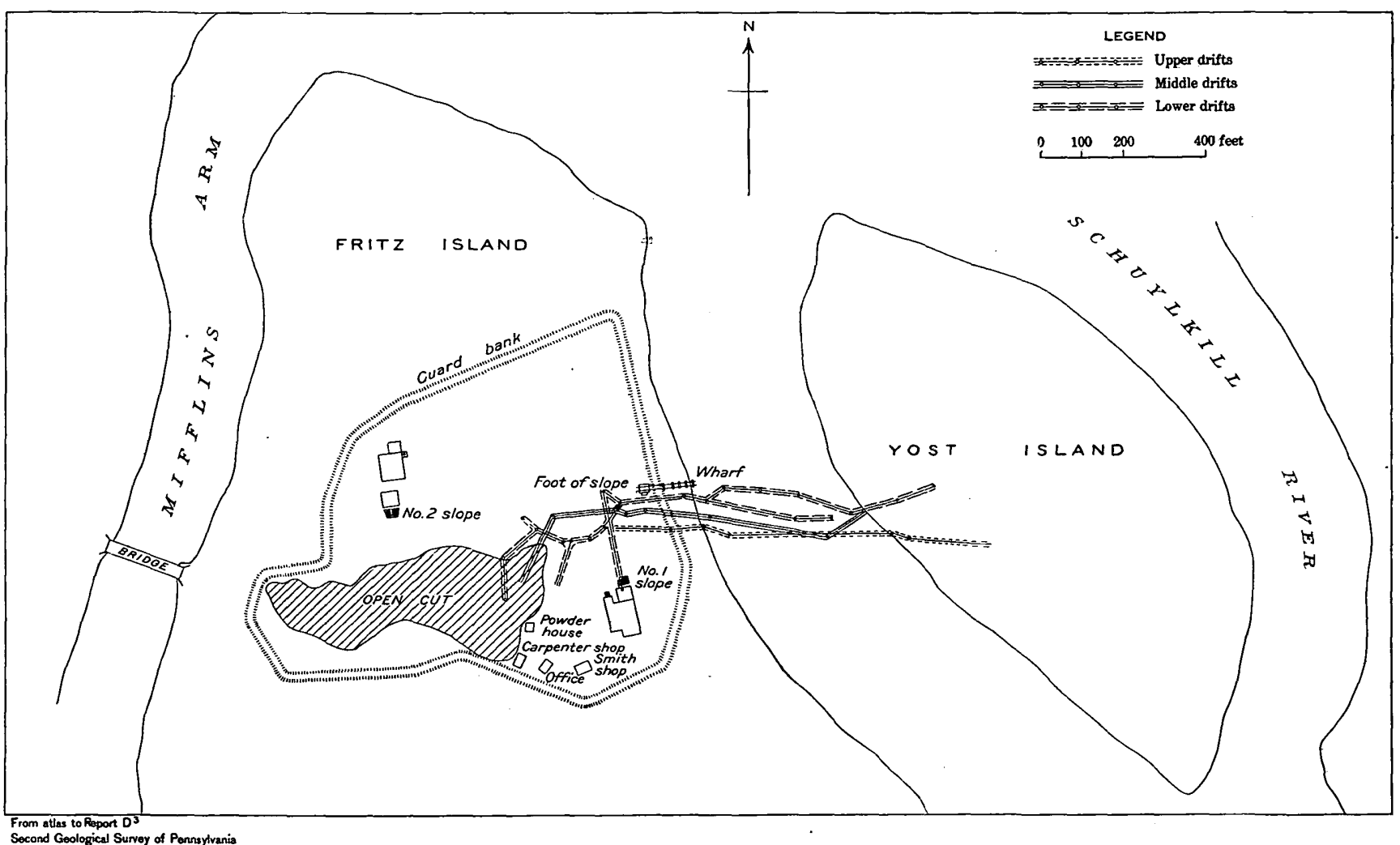

MAP OF FRITZ ISLAND IRON MINES, BERKS COUNTY, PA. 
worked to a depth of about 100 feet above the crosscut from slope No. 1. The position of slope No. 2 is about 300 feet northwest by west from No. 1.

In 1883 slope No. 2, which is sunk through rock, was down 122 feet on a dip of $40^{\circ}$ to $55^{\circ}$, averaging -perhaps $45^{\circ}$, but the direction of slope is not stated.

The open-cut workings seem to have had considerable importance, although no record has been found concerning the features which they exhibited. The old pit extends east and west and is nearly 300 feet in length.

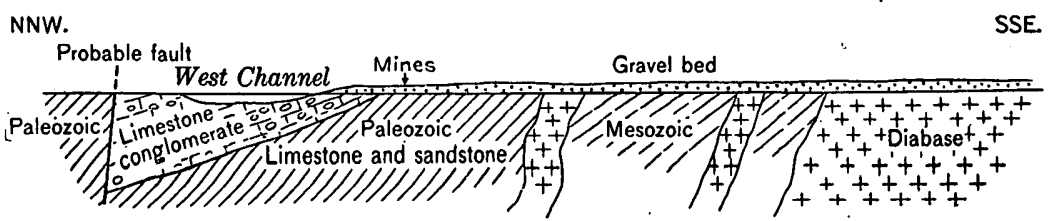

FIG. 4.-Sketch section at north end of Fritz Island.

The average daily production of the mine in 1883 was 25 to 30 tons, amounting to about 10,000 tons per year: At that time only one slope, No. 1, was being operated. The total yield up to 1883 was estimated at 250,000 tons.

The general relations of the different rocks indicated by the foregoing description are shown in fig. 4. Apparently there is a wedge of Paleozoic limestone lying between diabase dikes on the south and northward dipping conglomerate on the north, but it is not known whether the ore bodies followed the bedding of the inclosing rocks or not. On Fritz Island the thin edge of the wedge has been removed

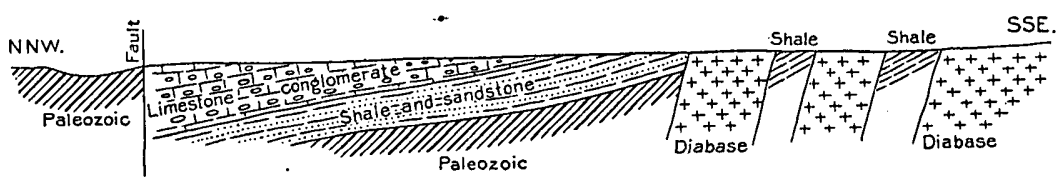

FIG. 5.-Sketch section along river bank east of Fritz Island mines.

by erosion, and the same relation probably exists near. the towpath on the east side of the Schuylkill, where, as reported, ore was discovered in a prospect shaft. Farther east, however, the Paleozoic rocks seem to be capped over by Mesozoic strata in some such manner as indicated in fig. 5. In the two figures just mentioned a fault is shown between the Mesozoic and Paleozoic areas, because the northerly dip of the conglomerate makes it difficult to see how this boundary could be formed by simple overlap. At many places the nature of the northern boundary of the Mesozoic is a vexing question, for though overlap is locally observable, elsewhere there is strong evidence of fault displacements of considerable amount. 
Future mining on Fritz Island is not likely, as the property has been acquired by the city of Reading to be used. as a sewer farm, but even if otherwise available the fact that the old workings run out beneath the river introduces an element of danger from flooding which might preclude further development. From a purely geologic standpoint it seems that the deposit might be expected to show considerable continuity in depth, for if the ore beds already worked are not actually continuous, others might be discovered by deep prospecting along the contacts of the intrusive masses of diabase.

The statement is made in the report by $\mathrm{D}^{\prime}$ Invilliers ${ }^{a}$ that mining toward the east was discontinued somewhere beneath Yost Island because of poor ventilation, so that it may be inferred that ore still remains at this place. The fact that ore was also found on the east side of the river near the towpath is a further indication favorable to prospecting in this direction. The rocks which have furnished the surface débris in the neighborhood are shales, sandstones, limestone conglomerate, and diabase, and the ore-bearing strata can hardly come to the surface except in a narrow wedge-shaped area near the river bank. As the northeast wall of diabase is followed in a southeasterly direction, the limestones are found to become covered by a rapidly thickening cap of the younger strata, so that it seems that any ore bodies existing will be found to lie deeper and deeper toward the southeast. In making the above suggestion it is assumed, as elsewhere in this report, that ore will not occur except near the intrusive rock, and that important bodies are not likely to be found where the diabase is in contact with other than calcareous strata. The only exception to this rule which has been noted is at Boyertown, where the Black vein and the East vein are both some distance away from the diabase intrusion.

\section{EAST BANK OF SCHUYLKILL RIVER.}

On the east side of the Schuyllkill, as on Fritz Island, the diabase is not a solid mass, two dikes being separated from the main body lying to the south by strips of Mesozoic shale. If these dikes continue downward and penetrate the ore-bearing limestones separately, crosscut tunnels would seem to be justified in order to explore all their walls, and also that of the larger intrusive mass beyond. This supposition is suggested by the occurrence of ore on both sides of the 100foot dike in the Island mine.

It would seem that if due care is taken to avoid breaking into the old Island mine workings, further prospecting from the east side of the river will be warranted by the probability of finding ore bodies similar to those formerly worked on Fritz Island. The known

a Second Geol. Survey Pennsylvania, Rept. D3, 1883,'pp. 337-338. 
presence of ore near the river bank would apparently justify a shaft, from which tunnels could be run as suggested above. Prospecting in this manner would probably be more satisfactory than by a series of drill holes.

WEST BANK OF SCHUYLKILL RIVER.

West of the river the presence of deep surface wash makes it impossible to determine whether the fields below the wagon road are underlain entirely by diabase or in part by sedimentary rocks Diabase is exposed opposite the north end of Fritz Island, but from the existence of two outlying dikes east of the river and at least one on the island, all with apparently east-west courses, it may very well be that this outcrop belongs to a mass lying north of the main intrusion. The question whether this is so or not is important and could be settled at slight cost by running two or three short tunnels from the bank of the western channel above the Fritz Island bridge. It is believed that if any other rock than diabase is found there would be a good chance of discovering ore bodies like those of the Island mine by systematic prospecting. - It is perhaps not likely that limestone conglomerate will be encountered, but if it should be present it would only be necessary to turn northward and penetrate this cap in order to reach the Paleozoic strata. If any ore should be found it would be desirable to determine how many outyling dikes of diabase exist and to explore carefully all contacts.

\section{ESTERLY MINE.}

About 4 miles due east of the Fritz Island mine and 2 miles south of Jacksonwald, on the W. Esterly farm, a small deposit of magnetite was once worked. William G. Rowe, of Reading, is authority for the statement that this mine furnished between 3,000 and 4,000 tons of ore. It was opened to a depth of 125 feet by a $58^{\circ}$ slope inclined toward the north, the drifts being run about 250 feet to the east. About 600 feet southeast of the Esterly slope an opening known as the Bishop shaft was sunk for 150 feet and a north crosscut driven for 200 feet, ending in garnet rock. A bore hole from the bottom of this shaft reached limestone conglomerate at about 300 feet.

The Esterly vein lies between a hanging wall of diabase and a foot wall of metamorphosed shale. The diabase is an intrusive sill included in northward-dipping strata. In the neighborhood of the intruded rock there has been considerable baking, and here and there such metamorphic minerals as garnet, hornblende, and magnetite are found. These minerals, with some chlorite, are present in the material on the old mine dump, and the silicates evidently occur in close association with the magnetite of the ore. Some limy material 
is to be noted, but no pure limestone; it seems, therefore, that this ore was formed by the replacement of shales under the mineralizing influence of the diabase.

The diabase is the outer of two concentric curving sills which follow the bedding of the Mesozoic shales and sandstones, here thrown into a rather sharp synclinal fold $(\mathrm{Pl} . \mathrm{V})$. The ore bed lies on the lower contact of the sill and, like it, strikes conformably with the inclosing rocks, nearly east and west, with a dip of about $50^{\circ} \mathrm{N}$. The deposit may be imagined to have considerable downward extent, though of course its continuity in this direction can not be affirmed. Along the strike it is rather short, as not more than 100 feet west of the slope carbonaceous and limy shale is exposed along the road, and though the situation is very near the diabase contact no magnetite has been developed.

No other magnetite is known to have been found along either side of this arm of the sill, but Mr. Rowe states that specimens have been plowed up in the fields near Spring Creek, between the northern arm and Stonersville. Though some prospecting ${ }^{\circ}$ was done in this vicinity, no magnetite was found in bed rock. It is possible that the mineral may have been float from a deposit situated near the diabase wall on the hill slopes above the creek, though it may have been derived from a pocket lying in the limestone conglomerate which covers considerable ground on the west side of Spring Creek south of the Reading turnpike.

In this place the strata of limestone conglomerate dip rather steeply to the southwest. This dip would carry them beneath the diabase sill, but the outcrops are so far from those of the diabase that it seems hardly likely that any important body of ore will be found in this rock, at least near the surface. In depth the conglomerates may be cut by the diabase, and if so there would be a chance for ore bodies in them and likewise for the occurrence of pockets at some distance from the intrusive rock.

On the surface shales probably come between' the conglomerate strata and the diabase, as they do in the vicinity of the Esterly mine, though the hill slope above Spring Creek on the south, and next to the conglomerate outcrops farther north, is hidden by an unbroken mantle of soil and diabase fragments. In the fields above the wagon road, however, the position of the diabase wall may be closely estimated from the presence of a sharp rise in the profile of the hill, and the contact could be reached almost anywhere by short tunnels.

In view of the fact that only limestone beds have thus far been found to yield really important ore deposits of the Cornwall type, it can not be urged that this contact is a particularly favorable place for prospecting, though it is undoubtedly the most likely place for ore occurrence in the neighborhood. No general recommendation that the 
diabase contacts should be prospected through their entire length seems warranted, though the discovery of ore at any locality would naturally lead to a rather careful search at other points.

Both arms of the two horseshoe dikes closely approach and probably actually reach the northern edge of the Mesozoic area, and inasmuch as limestone occurs everywhere north of the boundary it would seem that ore bodies might be expected at the localities where the diabase and limestone come together. It is believed, however, that the diabase does not intrude the limestone at any of these places, but instead that the Paleozoic and Mesozoic rocks come together along a fault which has developed since the younger strata in the synclinal fold were invaded by the two sills of diabase.

\section{BOYERTOWN DEPOSITS.}

GENERAT, DESCRIPTION.

The mining operations which have been carried on at Boyertown have developed the existence of five apparently separate bodies of magnetic iron ore, all of which exhibit the form of somewhat irregular layers of varying thickness. These ore layers seem to follow rather closely the stratification of a set of limestones and limy shales which constitute a transition between "No. I" sandstone and "No. II " limestone of the Paleozoic section, as given in the publications of the Second Geological Survey of Pennsylvania. In stratigraphic position these beds correspond with the ore-bearing strata at the Wheatfield and Fritz Island mines.

The mine openings are situated near the northwest edge of the Mesozoic belt, and the workings have shown that the three bestdeveloped ore bodies lie immediately beneath a Mesozoic basal conglomerate composed of limestone fragments up to an inch in diameter set in a paste of red clay. This conglomerate bed, with a generai southwest-northeast strike, dips toward the southeast, and beneath it the Paleozoic strata are so tilted that they. lie in nearly parallel position. The two other ore bodies occur well within the limy beds of the Paleozoic at contact of a mass of intrusive diabase (PI. VIII). The ore bodies just beneath the conglomerate are here called the East vein, the Hagy (sometimes known as the Eckert) vein, and the Warwick or Black vein. The deposits in contact with the diabase are known as the Rhoades and Blue veins. The East vein was worked from two inclined shafts situated southeast of Walnut street and known as Phoenix upper and middle slopes. The Hagy vein, outcropping south of the Reading road in the outskirts of town, was first worked by means of an open excavation known as the Hagy pit, afterwards by the so-called Eckert slope, and finally by the lower Phoenix or California slope. The Warwick vein has been worked 
both from the Warwick shaft and from the two shafts of the Gabel mine. In the latter mine it was called the Black vein. A body of ore ecountered in the lower workings of the California mine and known as ore No. 2 is believed by the writer to represent the northward extension of the Warwick vein. The Blue vein has been found only in the Gabel mine. The Rhoades vein has been opened from the surface at several places and also by means of two tunnels from the California slope.

It is suspected that connection may eventually be established between the Blue and Rhoades veins, also that the Warwick and Hagy veins are parts of a once continuous ore body separated by a fault. These points and the possible relation between the East vein and the Hagy vein are discussed on pages 58-60. The relative positions of the several mines are indicated on the map (Pl. VIII).

The strata which carry the deposits occur in a narrow strip lying between the region of gneisses and sandstones northwest of Boyertown and the Mesozoic area on the southeast. The length of this strip is at least 2 miles and possibly somewhat more, but all the known ore bodies occur within a distance of less than half a mile.

The situation of the deposits with respect to the Mesozoic rocks is similar to that of the Cornwall, Wheatfield, and Fritz Island deposits. Like all of these, they are associated with intrusive diabase, and though this association is somewhat less obvious at Boyertown than elsewhere it is sufficiently evident to justify the conclusion that the ores have been formed under the influence of the invading rock, as at Cornwall and other localities where ores of a similar type occur.

\section{GEOLOGY OF THE DISTRICT.}

Boyertown is situated near the northwest end of a roughly oval valley, 9 miles long from southeast to northwest, and about 5 miles wide. Ridges formed either by diabase sills or by sandstones and shales baked and hardened by the intrusive rock define this valley on three sides, the remaining or northwest side being formed by the Reading Hills, which are composed mainly of ancient gneisses, but contain also limestones and quartzites. From the ridges the strata dip toward the interior of the valley, which is thus structurally, as well as topographically, a broad basin. It is one link in a chain of four similar basins that extend nearly to Delaware River. Each of these basins is rimmed by diabase, the outcrops of which are nearly, if not actually, continuous. The great extent of the diabase, the continuity of its outcrop, and the persistency with which the intrusive rock follows the structure of the inclosing strata lead to the belief that it forms a practically unbroken sheet beneath all the basins that are surrounded by its outcrop. The basin here discussed is not com- 


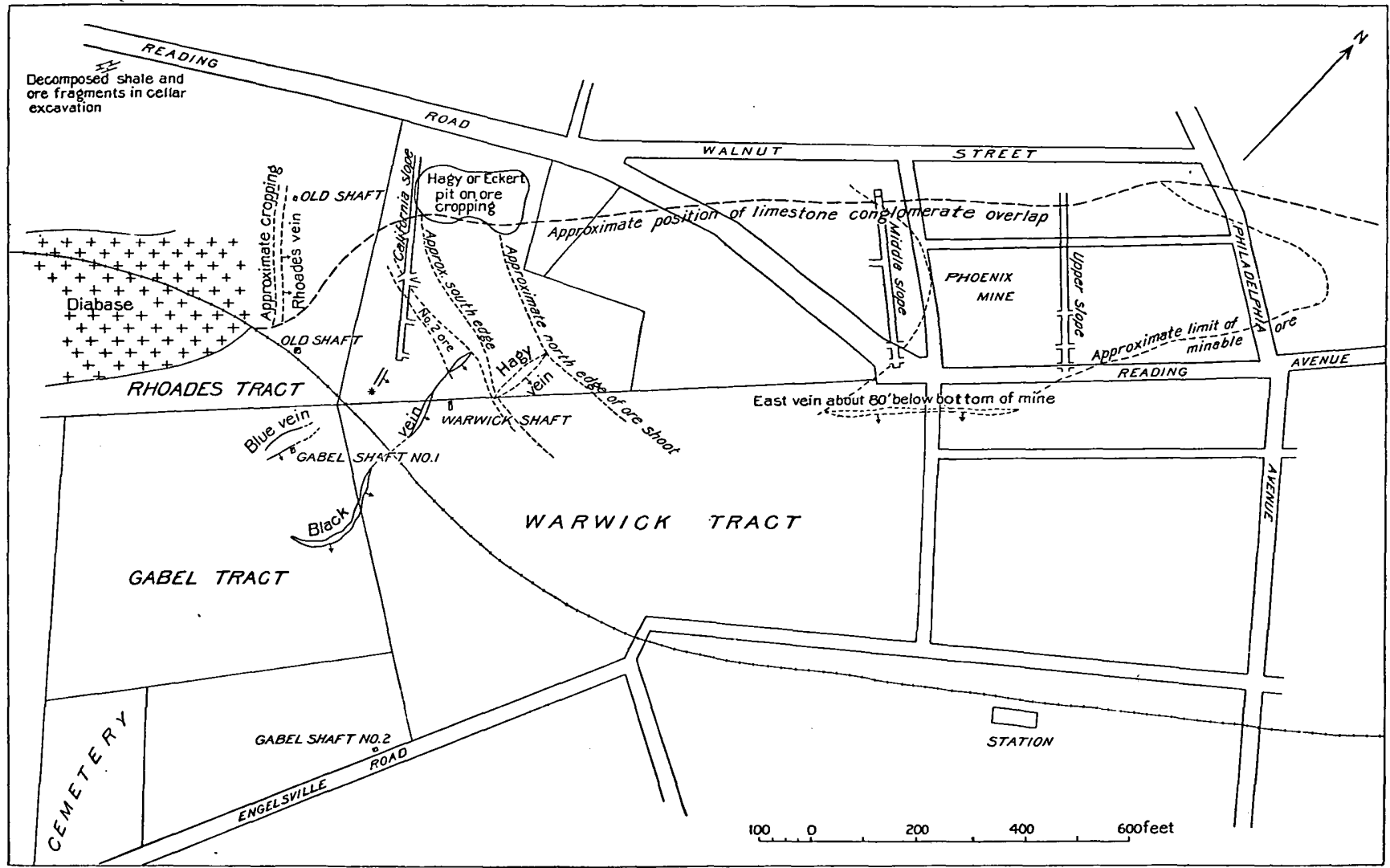

SURFACE MAP OF BOYERTOWN MINES, SHOWING RELATIVE POSITION OF ORE BODIES ON LEVEL SURFACE 400 FEET BELOW TOP OF GABEL NO. 1 SHAFT. 


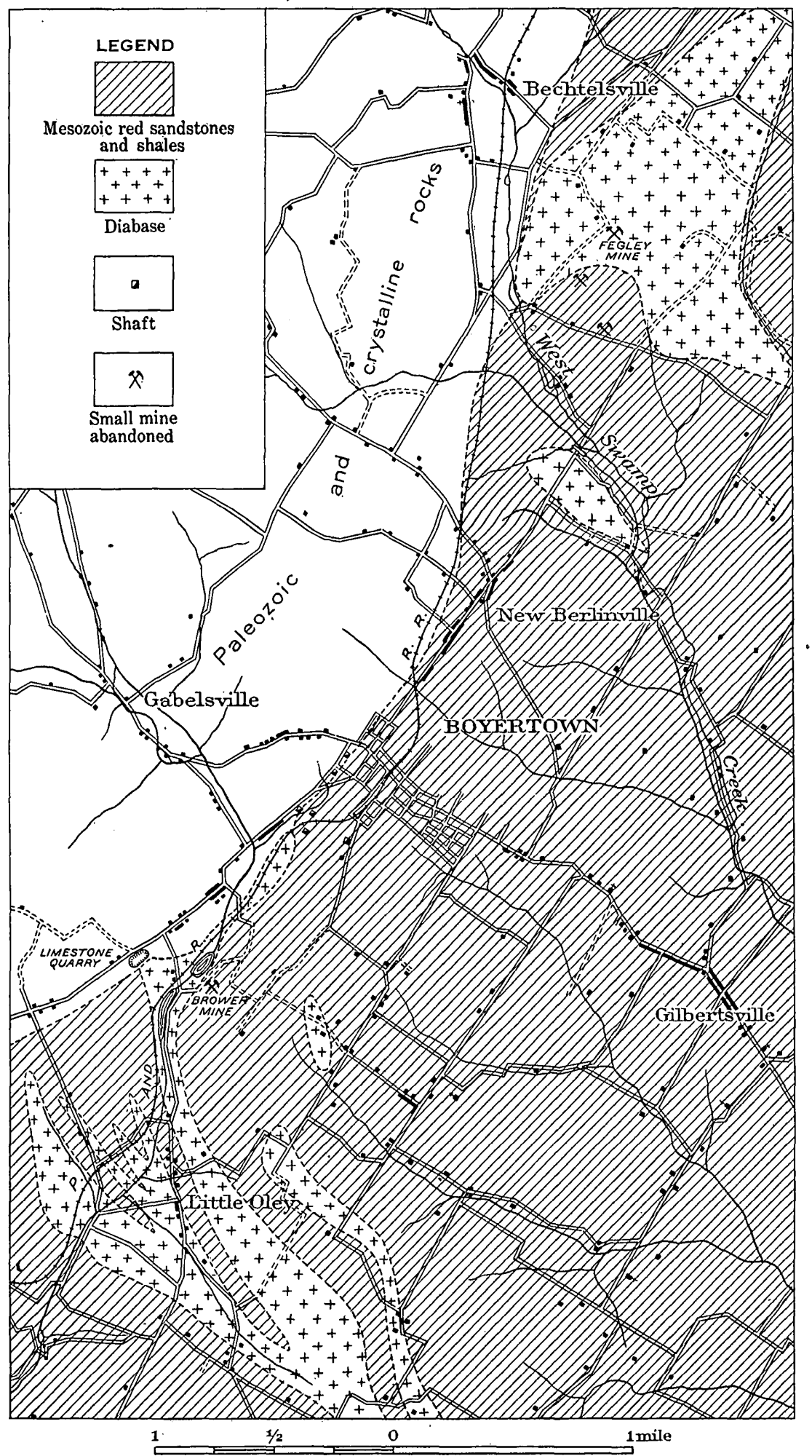

GEOLOGIC SKETCH MAP OF VICINITY OF BOYERTOWN, BERKS COUNTY, PA. 
pletely rimmed by the igneous rock, but it seems probable that the two existing gaps, one near Boyertown and the other 3 miles to the northeast (Pl. IX and fig. 10), are to be explained on the supposition that:in these places the invading rock was not able to force its way far enough upward to reach the present surface of the land.

Just.south of the mines the western slope of Gabel Hill is formed by diabase, which marks the northward termination of a curving mass of intrusive rock that follows the base of the ridge and the valley of Ironstone Creek to Colebrookdale station and farther south connects with the rim-rock sills on the southwest side of the synclinal basin described above. The sedimentary rocks adjacent to this diabase have been greatly metamorphosed, and Gabel Hill, together with the ridge running southward from it, has been preserved from erosion by the indurated nature of the shales and sandstones of which they are composed. The originally red sandstones have been bleached to a dull white or yellow. A few outcrops suffice to show that the strata strike parallel with the course of the sill and with the crest of the ridge and dip to the east and southeast toward the interior of the basin. North and east of the blunt end of the diabase outcrop a few exposures of sandstone have the natural red color of the Mesozoic strata and show no induration. In the Warwick mine, however, and in both shafts of the Gabel mine limestone conglomerate lying above the black ore is somewhat metamorphosed, garnet and hematite being developed in it. These minerals occur also in bowlders both of limestone and siliceous conglomerate on Gabel Hill. The surface distribution of the metamorphic effects conforms so closely with the extent of the diabase that the presence of common metamorphic minerals in the conglomerate that occurs in the mines points definitely to the presence of intrusive rock near by. To judge, however, from the descriptions of D'Invilliers ${ }^{a}$ and Willis ${ }^{b}$ the instrusive rock is absent from most parts of the mines. Small dikes were noted in the Warwick mine and diabase is known to lie beneath the Rhoades vein and in the Gabel No. 1 workings beneath the Blue vein. Willis shows this rock as the foot wall of both the last-named veins, and indicates its presence in the crosscut tunnel from the 496-foot level of the Warwick mine, which was opened in search of the Blue vein. It is thought probable that a rather direct underground connection may exist between the Gabel Hill deposits near Boyertown and the masses of the same rock occurring northeast of New Berlinville, and also between the latter and the diabase that outcrops east of Sassamansville.

From scattered exposures strata corresponding with those which carry the ore layers are known to extend about one-half mile south-

a Second Geol. Survey Pennsylvania, Rept. D3, vol. 2, pt. 1, 1883.

$\checkmark$ Tenth Census, vol. 15, 1886. 
west and 1 mile northeast of the mines, and they may continue considerably farther north beyond New Berlinville, beneath the alluvial wash of the swampy lands along the railroad. Shales including a dark carbonaceous layer have been revealed by an old pit in a field between the Reading turnpike and the railroad about half a mile north of the California slope, and shales broken down by surface weathering are exposed on both sides of the same road just where the trolley track leaves it and turns up the valley of Ironstone Creek. Decomposed shale was revealed in excavations for cellars made in 1906 on the south side of the road between the exposures last mentioned and the engine house at the California mine, and a few lumps of iron ore were found mixed. with the clay. This material was apparently. undisturbed, though it is possible that it may have been waste from the mines. A prospecting shaft situated between 500 and 600 feet northeast of Philadelphia avenue along the strike of the East vein showed the presence of carbonaceous shale which is reported to have been similar to some of the material associated with the ore, and which very likely represents the ore horizon, as the limestone conglomerate occurs near by. Fragments of similar limy and carbonaceous shale containing a little pyrite which came from a .slope half a mile farther northeast, on the east side of the railroad track opposite the clay pit and brick kilns, may still be found scattered over the field. A hole was drilled near by, but no details of this prospecting have been obtained. The clay used in the brick works near New Berlinville station is weathered shale, and in places where the decomposition is not complete the rock closely resembles that which outcrops southwest of the California mine along the Reading turnpike. North of New Berlinville no exposure of shale has been noted, though it probably occurs west of the railroad between the track and the narrow band of quartzite that is represented on the geologic map of the Reading and Durham hills accompanying the Berks County report by D'Invilliers. From the mines northeastward to New Berlinville the shales and accompanying limy beds are overlapped by the Mesozoic strata, the strike of which, though variable from place to place, runs in general nearly parallel with the strip of Paleozoic rocks. The dip in both sets of rocks is toward the southeast and, as already noted, the strata lie nearly parallel. From the Rhoades mine toward the southwest the diabase sill appears to separate the strata of the ore-bearing group from those of the Mesozoic almost as far as the Gresh limestone quarry, a short distance east of which the sill turns southward into the Mesozoic area. At the quarry baked Mesozoic shales are seen almost in contact with the massive blue Paleozoic limestone. The hill above the quarry is covered with fragments of whitened and indurated sandstone. 


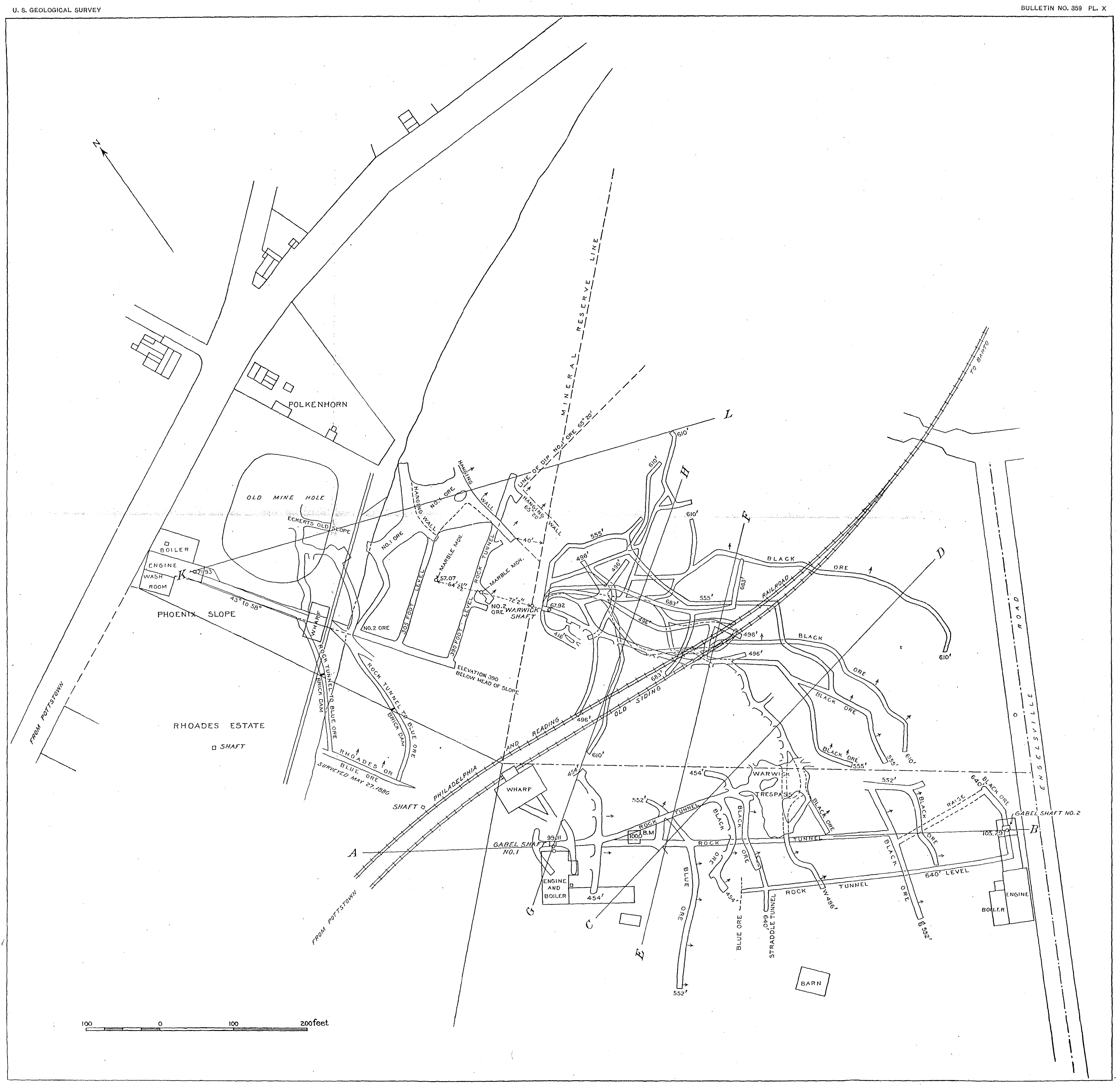




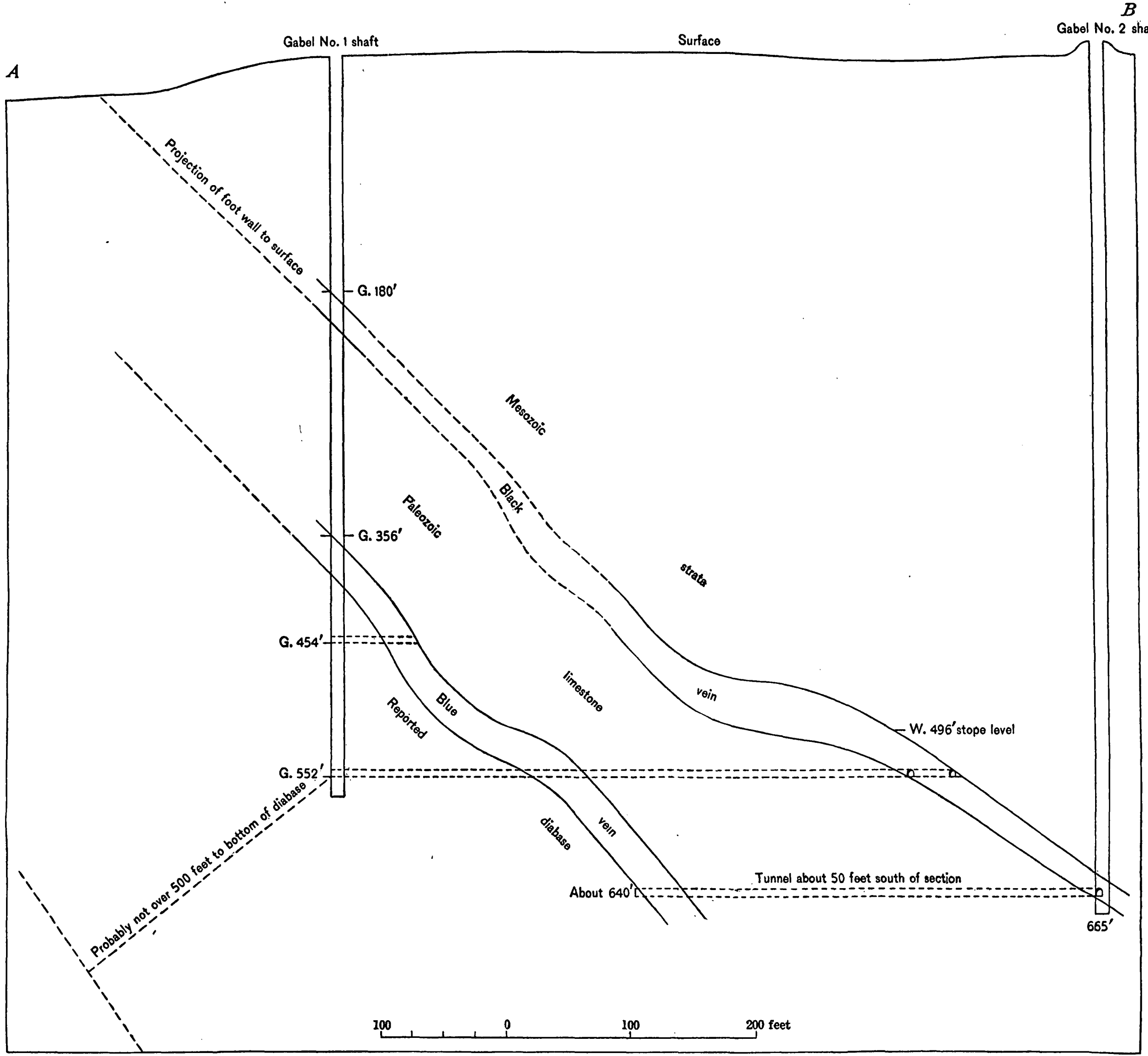

CROSS SECTION AT BOYERTOWN MINES (ALONG LINE A-B, PL. X). 
THE WORIKINGS.

All the mines of the Boyertown group were flooded when the writer visited the locality, and for this reason no first-hand information concerning the underground geology of the ore deposits enters into the present descriptions. The facts available in regard to the geology of : he mines are those recorded by Willis and D'Invilliers, whose descriptions are quoted below. For the map of the workings which forms $\mathrm{Pl}$. X acknowledgment is due the former engineer and superintendent of the Phoenix mines, Mr. J. H. Harden, of Phoenixville, by whom it was in part drawn from original surveys and in part compiled from data furnished by the several companies which formerly owned the mines. The workings of the 640-foot level of Gabel shaft No. 2 have been added to Mr. Harden's map from notes of a survey in possession of W. H. Dechant, successor to the practice of Kendall Brothers, civil engineers, formerly located at Reading. The cross sections of the mines (Pls. XI-XV) have been constructed from the data afforded by the mine maps, with the aid of sketches made by Mr. Harden. Their purpose is to show the general attitude of the veins, and they do not take account of the many existing irregularities of thickness.

DESCRIP'TIONS BY WILIIS. ${ }^{a}$

The Phoenix mines present the simplest structure. Two inclines, having an average slope of $46^{\circ}$, are sunk on the ore, between a hanging wall of Mesozoic red sandstone and a foot wall of dark-gray limestone. Drifts * * * have been driven off on either side of the incline and the ore removed by stoping. The bed varies from 7 to 12 feet in thickness, and near the hanging wall there is usually a selvage of chloritic slate, which comes down in mining. The strike is quite regular, about northeast and southwest, and the beds have the apparent prospect of continuing indefinitely in either direction; just southwest of the lower incline the bed is pinched out, however, and no exploration has been made to ascertain whether it continues or not.

A shaft, known as Eckert's, *** was sunk a short distance northeast of the California incline, and "Eckert's vein " was opened by it. The Phoenix company owns part of the mineral right on this "vein," and the California incline was sunk through rock to develop it and "Rhoades's vein," which was known by surface workings.

$* * *$ The northeast drifts of the California mine reach the southwest end of Eckert's ore, while two long crosscuts have been driven through limestone to Rhoades's deposits. Eckert's is like the Phoenix in geological relations, but strikes nearly north and south, with a dip to the east.

Rhoades's vein strikes at right angles to the Phoenix, southeast and northwest, and dips northeast; it las a hanging wall of limestone and foot wall of trap, and in this resembles the deposit opened by the Gabel shaft [Blue vein]; the ores obtained from the two openings are also very similar, and the differences of strike and dip are hardly sufficient in so disturbed a corner to render it improbable that they belong to the sanıe deposit. 
The lowest working in the California mine, on Eckert's vein, is 218 feet frow the surface at the top of the incline; the dip is about $45^{\circ}$ toward the east. This drift is 240 feet from the Warwick shaft, measured on the map. Ore was first struck in that shaft at a depth of about 400 feet, probably 425 feet below the top of the California incline.

A dip of $38^{\circ}$ to $40^{\circ}$ would place a southern extension of Eckeit's vein in the position of the ore cut in the Warwick shaft. It does not follow that the ore body is continuous from the Warwick workings up to the California drifts. In fact, the trap which lies west of the Warwick shaft and that penetrated in the long crosscut toward the Gabel mine render it very improbable that there is an undisturbed body of ore here; but it does seem probable that the Warwick, the Eckert, and perhaps the Phoenix beds, which all have a red-sandstone hanging wall and a limestone foot wall, are disturbed portions of the same originally connected bed.

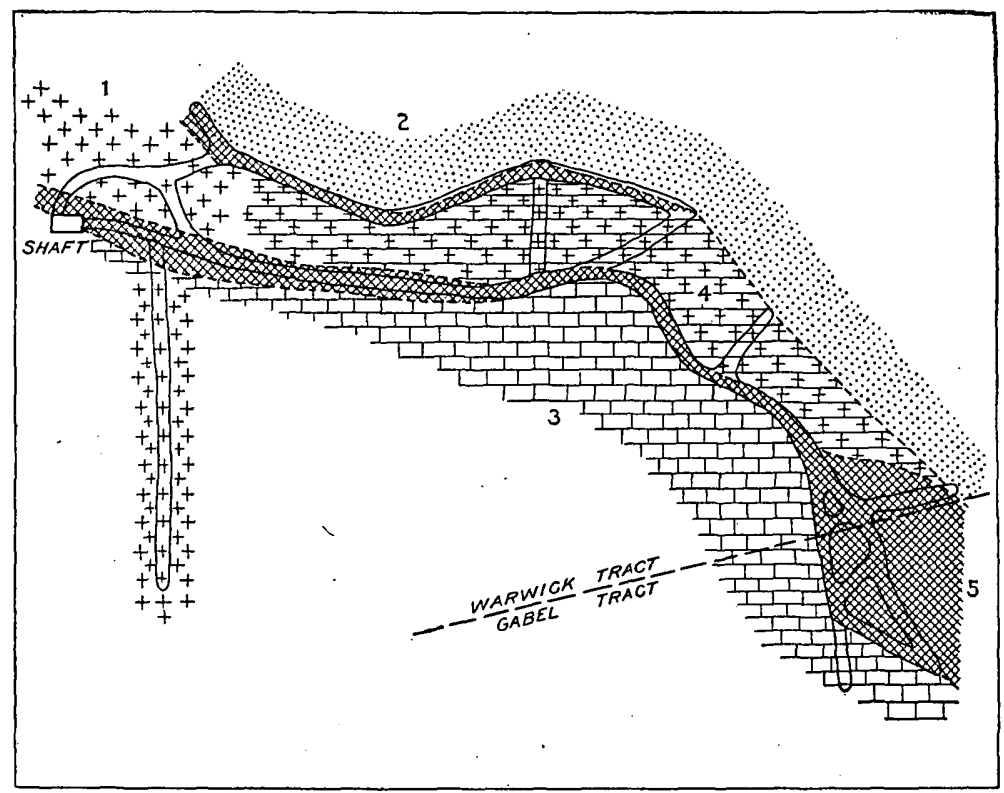

FIG. 6. Plan of upper or 496-foot level, Warwick mine, after Willis. 1, Diabase; 2, Mesozoic sandstone; 3 , limestone; 4 , limestone mixed with ore; 5 , magnetite ore.

A special map is herewith given of the Warwick mine [fig. 6]. It is opened in the most disturbed portion of the belt, and the apparent development of two parallel ore beds, together with the exceptional facilities afforded by the kindness of Captain Polkinhorn, led to careful study of it. In the long drift on - the middle level, toward the south, there is a well-defined limestone foot wall. The hanging wall of red sandstone is also uninterrupted; but between the two, and especially in the northern end of the mine, the limits of the ore are very ill defined. The wall is usually mixed limestone and ore, and mining is left off simply when the proportion of ore to limestone becomes too small to pay.

Where the ore body turus southward the upper. bed of ore approaches the lower bed, and it.will probably be found that there is but one extending southeastward beyond the next turn in the Gabel property. The variations in the thickness of the ore bed and the positions of the associated limestone, red sandstone, and trap are given in the accompanying special map. 
U. S. GEOLOGICAL SURVEY

C

Surface
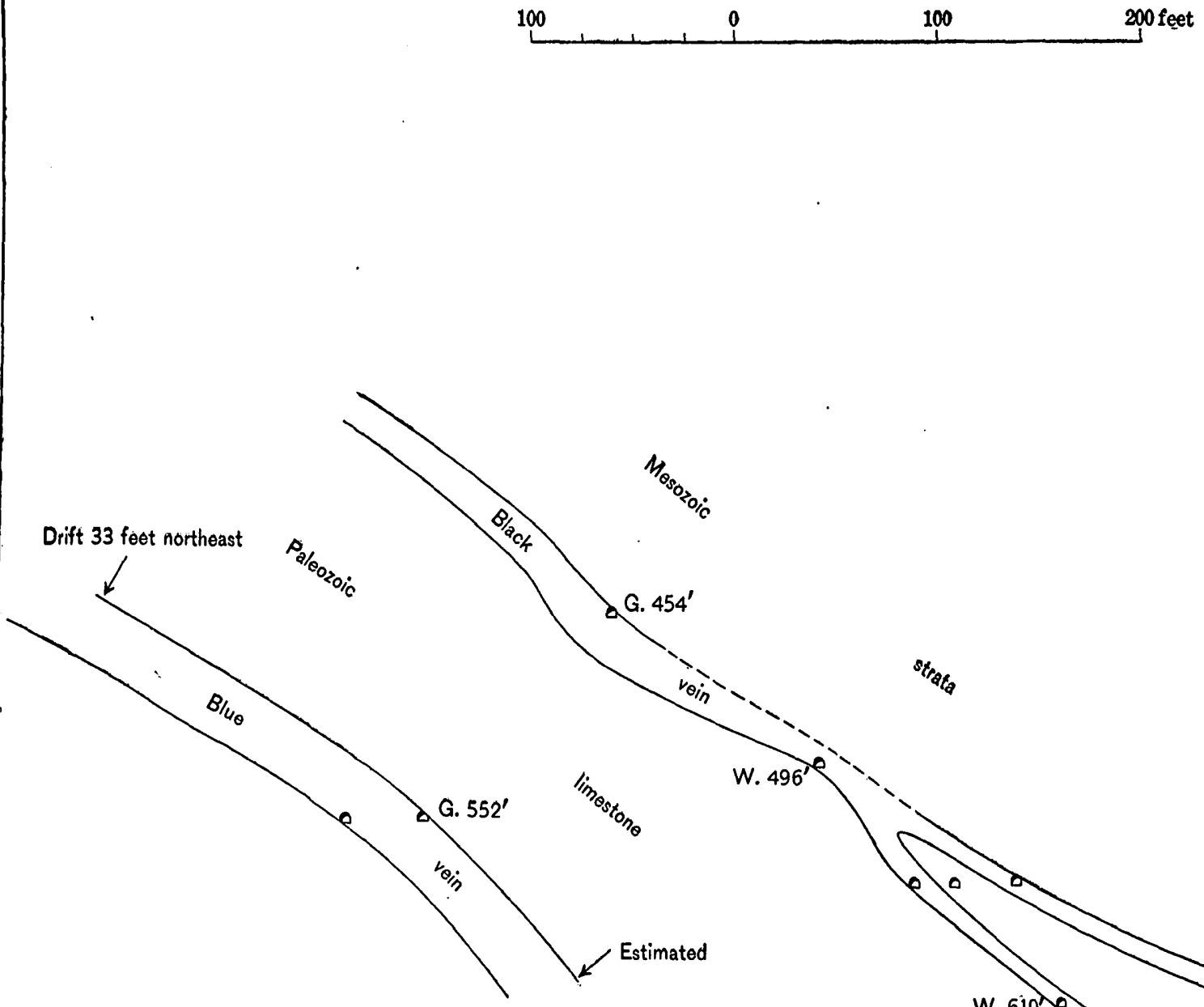

CROSS SECTION AT BOYERTOWN MINES (ALONG LINE C-D, PL. X). 
Accepting the inference that the Warwick, Eckert, and.Phoenix deposits have criginally formed parts of one bed, though now disturbed and separated by "pinches," it is difficult to understand how the Blue (Gabel) vein and the Rhoades vein can ever have been part of that bed.

The foot wall of the Phoenix and the Eckert mines is apparently tilted, but otherwise a little-disturbed and continuous stratum. Away from the trap, which has confused the deposit near the Warwick shaft, the limestone foot wall is in that mine also well defined. The long cut driven from the Gabel bed to the large deposit in the south end of the Warwick mine passes through 175 feet of limestone. The same material lies uninterruptedly between the Eckert and the Rhoades beds. Hence it seems highly probable that there are here two distinct deposits of ore. With this in view, it would be interesting to know the results of exploration north of the Phoenix mines.

DESCRIPTIONS BY D'INVILLIERS.

The following descriptions of the several mines are abridged from D'Invilliers's account of the Boyertown mines:

Phoenix upper and middle slopes. ${ }^{a}$-These slopes are 350 feet apart and both work the same body of ore, averaging from 12 to 15 feet in thickness, though at many places swelling into bunches three times as large in different portions of the different gangways. The dip of the ore averages about $45^{\circ} \mathrm{SE}$. The upper slope is 353 feet deep, vertical measurement, its top being located 6 feet higher than Gabel shaft No. 1. The lowest drift is driven on this slope from the bottom for about 150 feet each way northeast and southwest, but the courses have never been surveyed, and consequently could not be located. Forty-three feet vertically above this is the middle drift, likewise driven each side of the slope about 160 feet northeastward and 300 feet southwestward to the middle slope. The upper drift is 267 feet below the.surface and 43 feet above the middle gangway, and has been driven each way about 300 feet, connecting on the southwest with the middle slope, as on the lower level. ${ }^{b}$

The top of the middle slope is at the same elevation as the upper one, and it is about 310 feet long, with two levels corresponding and connecting with the upper and middle levels on the upper slope. The middle slope was driven in rock, but the upper slope was driven on ore all the way, and as the ore body here is much softer than in the middle slope a great deal of trouble and expense has been necessary to keep the slope in repair. This has led to its proposed abandonment and to the erection of permanent buildings at the middle slope, from which all future mining will probably be carried on. These improvements were hardly consummated when the dull times of 1880 and

a D'Invilliers, E. V., Geology of Berks County : Second Geol. Survey Pennsylvania, Rept. D3, 1883, pp. 314-316.

${ }^{b}$ This level was afterward extended to a distance of about 500 feet northeast of the slope and reached beyond Philadelphia avenue, according to the statemnet of Richard Richards, former foreman of the Phoenix company. 
1881 led to the closing of all the mines, and the two upper slopes are still filled with water [1883]. It is likewise proposed here to further test the property by driving northward from the slope to prove the presence or absence of the underlying blue ore bed. ${ }^{a}$

The true foot wall in both these slopes is an altered syenite carrying thin seams of earthy magnetite with dull luster, in many places massed or bunched, and showing but little crystallization. ${ }^{b}$ The syenite is filled with pink feldspar nodules, hornblende, and epidote, all distinctly stratified. In the upper slope, however, a dark greenish-black unctuous limestone layer is found at many points between the main body of the ore and the true foot wall, much of it carrying chert in large masses. The top wall is a decomposed, light greenishgray, serpentine limestone, slaty and carrying crystals of pyrite. The ore rock is generally an impure conglomerate limestone carrying masses of dull-colored crystalline limestone, serpentine, and magnetic ore, but the bulk of it is a green to black dolomite with coatings of calcite. The ordinary run of the mine shows a mixture of magnetic iron ore, with limestone and minute crystals of iron pyrites diffused through the mass. Locally the pyrite occurs in large and well-defined crystals.

Phoenix lower slope, or California mine. ${ }^{\text {- }-T h e ~ d e v e l o p m e n t s ~ h e r e ~}$ consist [1883] of a slope about 300 feet long, from which three levels have been driven toward the northeast for the purpose of working the Hagy ore bed, and two toward the southwest to meet the Rhoades vein. The lowest level was driven first for about 50 feet through a dark quartzose sandy rock of a bluish color. The course of the gangway being thought to be turned too much toward the east to strike the ore, the next 50 feet was driven more to the north, likewise through rock, until at a distance of 110 feet from the foot of the slope ore was struck. The original northeast course was resumed and carried through ore for 50 feet more. The gangway at the time of visit showed a chamber fully 22 feet wide, without showing foot or hanging walls. The dip of this western body of black ore is probably toward the southeast at a steep inclination.

The middle drift is about 40 feet vertically above the lowest, and in driving northward from the shaft the same characteristics were met as already noted in the lower level. The drift is not parallel to the lower level, but turns somewhat more toward the northeast. For the first 30 feet it passed through rock, beyond which the ore body was met in a rather pinched condition.

The upper level is driven northward from the slope about 176 feet vertically below the surface of the ground. It extends for about 80

a Mr. Richards states that this exploration was made, but that no ore was found.

${ }^{b}$ Compare with statement of Willis, p. 49.

c D'Invilliers, E. V., op. cit., pp. 308-311. 


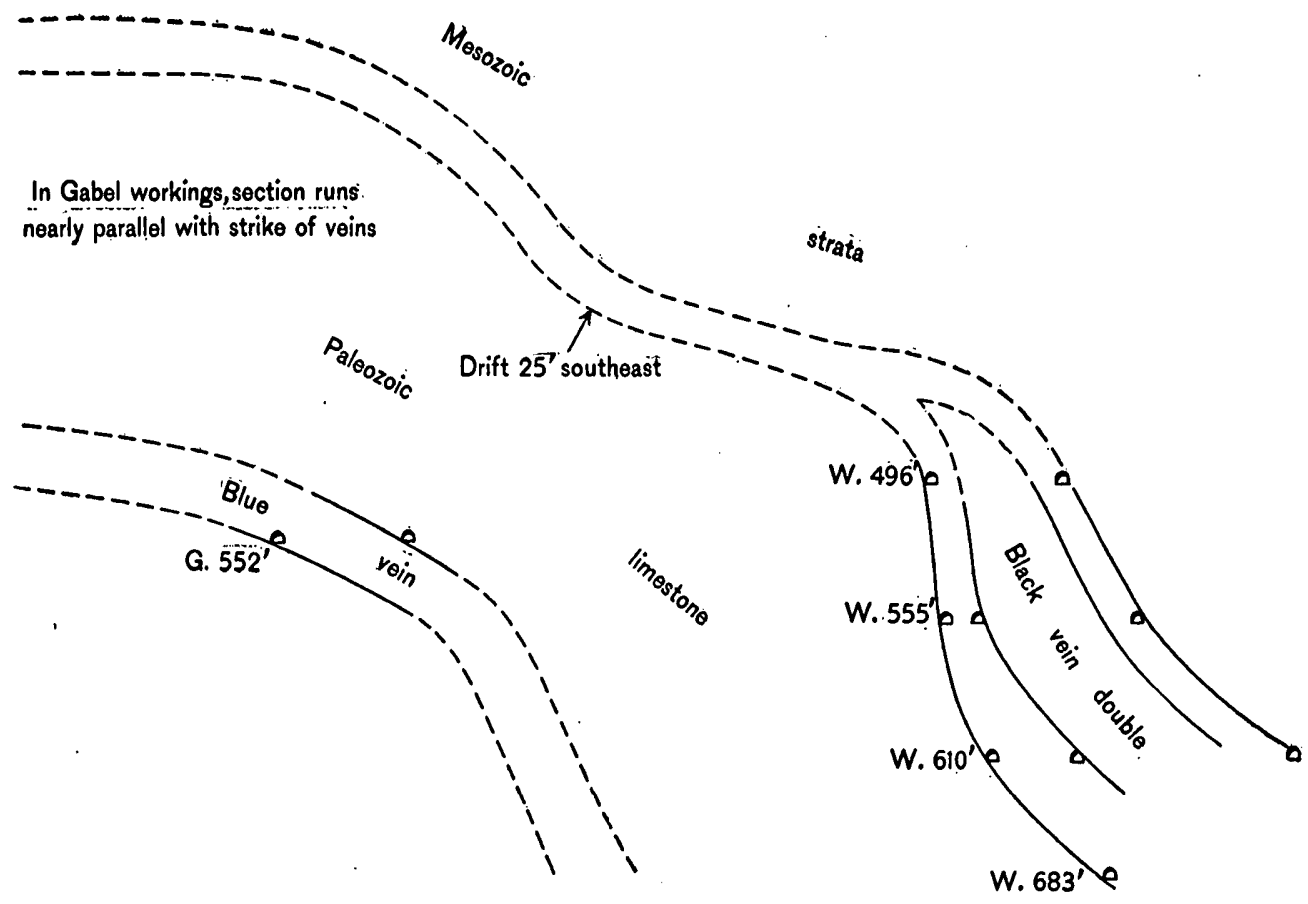


feet along the south line of the old Eckert open cut, and the ore body pinches toward the northeast.

Exploration has been carried on south of the slope, where the workings consist of a rock tunnel driven southwestward for about 200 feet at a depth of about 176 feet through a mixed micaceous and quartzose rock to the Rhoades vein, which strikes about S. $25^{\circ} \mathrm{E}$. and dips a little east of north at an angle of $50^{\circ}$. A similar rock tunnel was driven from the middle level in a nearly parallel direction, and from its extremity a raise has been opened to strike the vein on the upper level. A fine face of ore 30 feet thick is exposed in this middle level, but, owing to its inferior quality as compared with the Hagy ore, work has been suspended [1883]. The thickness of this bed varies greatly, as is the case throughout all the mines. The gangue is similar to that of the Hagy mine, being mostly silica, lime, and magnesia, but the ore is leaner in iron and carries more sulphur and a little copper, being identical in composition and physical attributes with the blue ore of the Gabel mine. In the Gabel mine the Blue vein is separated from the overlying Black vein by 150 feet, more or less, ${ }^{a}$ of impure limestone, but the Hagy and Rhoades veins are divided by a rock which is apparently a rotten quartzose gneiss, though the gangue of the ore itself in each place is largely limestone. ${ }^{b}$

Warwick mine.c-The Warwick mine has three levels [1883], with numerous gangways and counter gangways, many of which have been long since abandoned and could not be explored. The first level is 420 feet vertically below the surface, the second 500 feet, and the third 567 feet [corresponding with 416 -foot, 496 -foot, and 555-foot levels as given on $\mathrm{Pl}$. $\mathbf{X}$ ]. Two gangways were driven on the 500foot level, one on the hanging wall, which is generally Mesozoic, the other extending toward the southeast and thence south into the Gabel property and showing generally a limestonce foot wall. The average horizontal distance between these gangways is about 50 feet, which would give a thickness of about 25 feet of ore, measured at right angles to the dip. The space between, however, is by no means entirely occupied by ore, but contains numerous horses of serpentine, limestone, and greenstone, as well as many occurrences of pinching where the foot and hanging walls come together. Pinching is particularly noteworthy in the north gangway, where about 150 feet from the shaft the ore is only from 3 inches to 1 foot; and again at the end of the gangway, where the ore is entirely cut off.

The ore is found everywhere to lie in lenticular-shaped bodies, thinning out in the line of strike and swelling to immense bunches in

\footnotetext{
"One hundred and sixty feet, as measured on the map.

$b$ To judge from the workings on the 176 -foot level of the California mine, the horizontal distance between the Hagy vein and the Rhoades vein is about 175 feet, but the two veins strike in very different directions-in fact, at an angle to each other of about $45^{\circ}$. A. C. S.

c D'Invilliers, E. V., op. cit., pp. 320-324,
} 
the center, variously mixed with limestone, with which it seems to be here and there intimately interstratified. A fine illustration of this relation was furnished in the lower [454-foot] level of the Gabel mine, where in a piece of limestone 6 inches thick there were four bands of interstratified ore from $\frac{1}{2}$ to 1 inch thick.

From the 500-foot level to a point 90 feet out from the shaft a crosscut was driven S. $40^{\circ} \mathrm{W}$. in search of the Blue vein found in the Gabel mine. It is probable that this bed exists in the extreme southwest corner of the Warwick tract, but, except at lower levels, it would not pay to stope it, as it must within a short distance pass into the adjacent properties.

The crosscut was not driven far enough to reach the Blue bed, for the slight development of this vein in the Gabel mine shows that it has a decided tendency to bear toward the northwest, in the direction of the lower Phoenix slope. The crosscut was closed at the time the nine was examined, but it was said to have been carried first through 1.0 feet of limestone, then 4: feet of ore, and for 143 feet through quartzose sandstone. ${ }^{a}$

From a point beneath the railroad to the boundary with the Gabel property the south gangway on the 500-foot level is driven through limestone and ore, the former being the general foot wall and dipping about $35^{\circ}$ SE. A great deal of ore has been obtained from stopings carried up from this gangway along the foot wall. Masses of calcite, bearing clusters of pyrite, are seen in numerous places accompanying the ore.

Close to the property line the north edge of an immense body of ore appeared, and in parting the drift to work it the ore was found to be fully 40 feet thick. The absence of connected surveys led to the continuation of both drifts into the Gabel property, from which fully 8,000 tons of ore was eventually extracted. A magnificent pillar of excellent black ore still remains as the support to the roof of this immense chamber. A crosscut from the foot to the hanging wall was in ore for its entire length.

Inspection of the lowest 567-foot level in this mine [555-foot level of Pl. X] will show that two gangways have been opened, connected in two places by crosscuts.

In the two parallel gangways driven eastward from the shaft to meet the ore body a considerable mass of limestone was driven through, extending as far as 125 feet from the shaft, after which ore was encountered to the Mesozoic conglomerate hanging wall, dipping here $50^{\circ}$ to $55^{\circ}$ a little south of east. The last 60 feet of the southern of these two drifts was entirely in ore, which here spreads out to a pinch within about 30 feet to the northeast along the main gangway, branching off from the north crosscut. The quality of the ore here

a The rocks through which this tunnel was run are shown by Willis as diabase. 
G

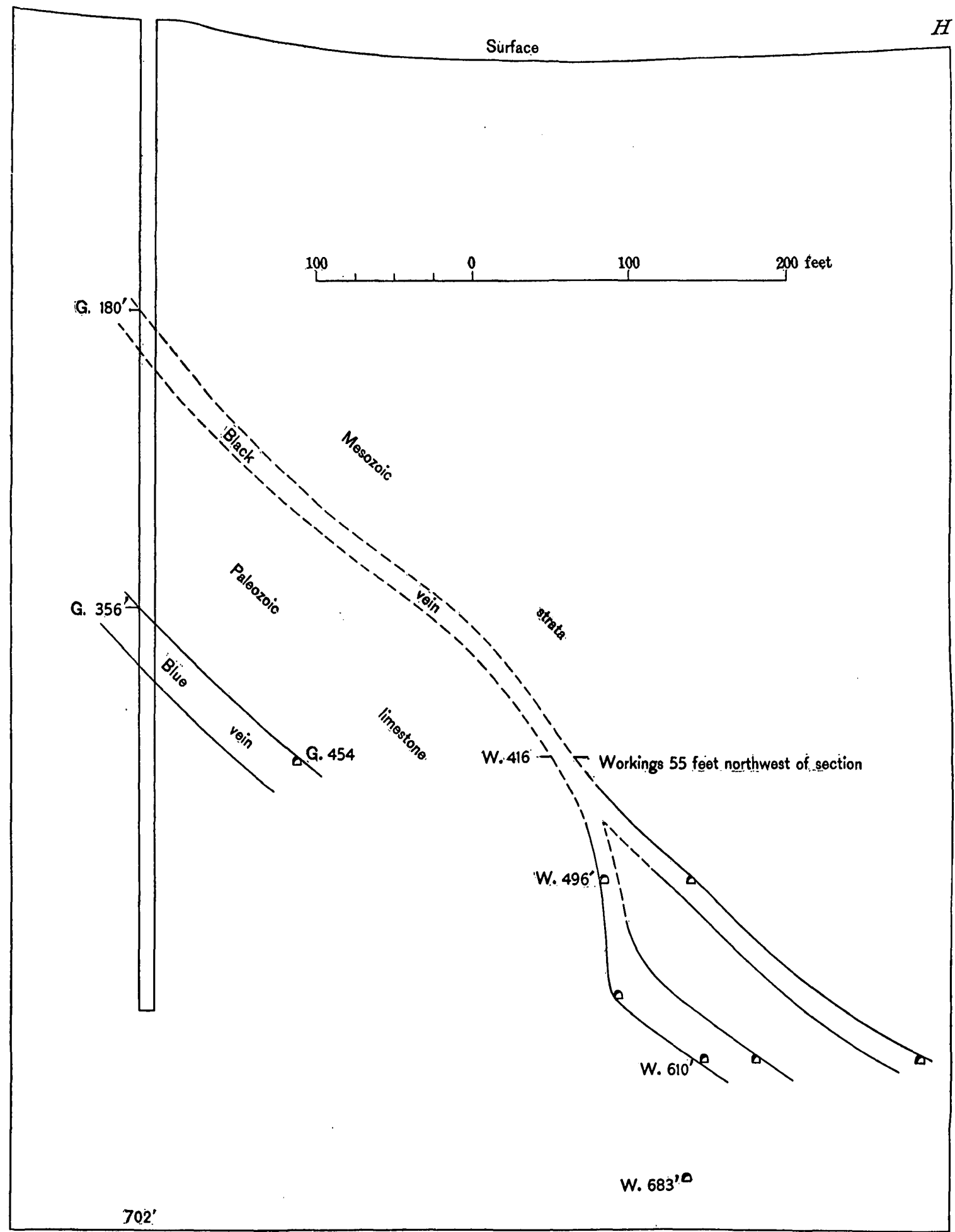

CROSS SECTION AT BOYERTOWN MINES (ALONG LINE G-H, PL. X). 
was excellent, but it was soon cut off by the meeting of the limestone and the Triassic measures [conglomerate]. To the south-southeast, along the hanging-wall gangway, the ore gradually thins away, and about 60 feet below the south crosscut it ranges from 3 inches to 1 foot. This pinch corresponds closely in position and character to that already mentioned as occurring on the 500-foot level, and the gangways are essentially parallel. The pinch on the hanging-wall gangway extends for 50 feet, to a point where the gangway makes a decided turn toward the S. $40^{\circ}$ E.; here another body of ore was encountered, 10 feet thick and swelling into the hanging wall, but pinching again in about 35 feet. This ore was stoped up for about 40 feet, where it was found to extend back over the pinch, thus showing the presence of bulging and thinning on the line of dip. The S. $40^{\circ}$ E. course extends for 120 feet to a point under the railroad, where the gangway turns southward and shows a limestone top. Sixty feet beyond, a greenstone dike was encountered similar to that occurring in several places in this and in the 500-foot level along a line from this point to the shaft. These dikes are nowhere of great thickness, and generally dip to the northeast. Where diabase is present it usually forms a true foot wall, no ore being found beyond it, but in the 567-foot level in the hanging-wall gangway it partakes more of the character of a horse, having ore on both sides.

The foot-wall gangway on this level is almost entirely in ore, in many places with a very steep dip and in one place even overturned. Inspection of the mine map will show that the foot-wall gangway of the 567-foot level lies very nearly underneath the foot-wall gangway on the level above. On both levels the gangways have a general curve convex toward the east, and toward the south the dips become lower and lower until near the Gabel property line they do not average over $35^{\circ}$ and here and there fall to $20^{\circ}$. Because of the low dip in the southern part of the mine most of the stoping has been confined to the 500-foot level.

A little development has been made on the 420 -foot level, but here the dip of the vein carries the ore beyond the property limits within a short distance, so that no extensive work has been done.

Gabel mine. ${ }^{-}$A vertical section through the Gabel No. 1 shaft shows-

Banded shandstones, and conglomerate, with a layer of altered mud rock about 5 feet thick at the bottom

Black bedded ore, folded and broken, and consisting mostly

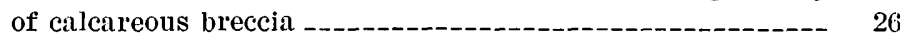

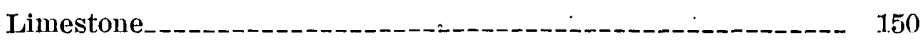

Blue ore bed (measured across the bedding 20 feet) -.-.--.-- 55

Chloritic rock or greenstone [probably diabase]-_-_-_-_-_--- 74

a D'Invilliers, E. V., op. cit., pp. 328-330. 
The mine has two levels, the upper 180 feet [160?] and the lower 474 feet [454]. Some development was carried on in the upper level close to the shaft, but the ore was greatly mixed with a light-green limestone gangue and in addition was greatly broken and folded. The underlying limestone was similar to that found in the Warwick mine, being mostly a serpentine-green limestone of a light color, but the gangue-rock limestone is much darker and in places black from the contained ore.

While mining in the upper level the Gabel Company became convinced of the trespass that had been made on its property through the 500-foot level of the Warwick mine. From the 474-foot level a main gangway was started toward the southeast, in which the blue bed was struck 30 feet from the shaft. This ore extended for 33 feet, the vein dipping about $60^{\circ}$. At the Blue vein the course of the gangway was turned somewhat to the left, and the remaining part of the gangway was entirely in limestone, at first dipping rather steeply but afterward flattening as the Black vein was approached. About 175 feet beyond the hanging wall of the Blue vein the foot wall of the Black vein was struck. The gangway came into the Warwick Company's stopes, which had been driven up from its 500foot level on a dip of about $35^{\circ}$. In the Gabel shaft the two ore beds and the strata which lie between them all dip about $45^{\circ} \mathrm{S} .55^{\circ} \mathrm{E}$.

The ore beds in the Gabel mine are like those in the other shafts. They occur in masses and bunches 40 feet thick, which pinch out to mere leaders and are therefore by no means continuous bodies of ore. The ores, however, show one difference, in that they are harder and more compact than in the other mines, probably on account of their proximity to the Gabel Hill. dike, which may have exerted some influence in altering their physical properties.

From the 474-foot level two gangways have been driven in the foot wall of the Black ore bed. Owing to its great thickness here and large limestone partings, stoping has been carried up almost to the shaft, where the Black vein was cut 180 feet below the surface, thus proving the identity of the brecciated bed there found with the magnificent body of ore in the lower part of the mine.

The Warwick gangways have likewise been extended along the hanging wall [" new red"- that is, limestone conglomerate], but not from the 500 -foot level, being started from the stopings above. These drifts along the hanging wall, as well as those on the foot wall, have been carried a considerable distance to the south; two of them being at least as far out as the barn. These gangways exhibit the tendency of the ore body to swing around Gabel Hill.

Some stoping has been done on the Blue ore bed, but the inferior quality of this ore delays its extended development. The company intends [1883] to sink another lift in the near future, from which 
$K$

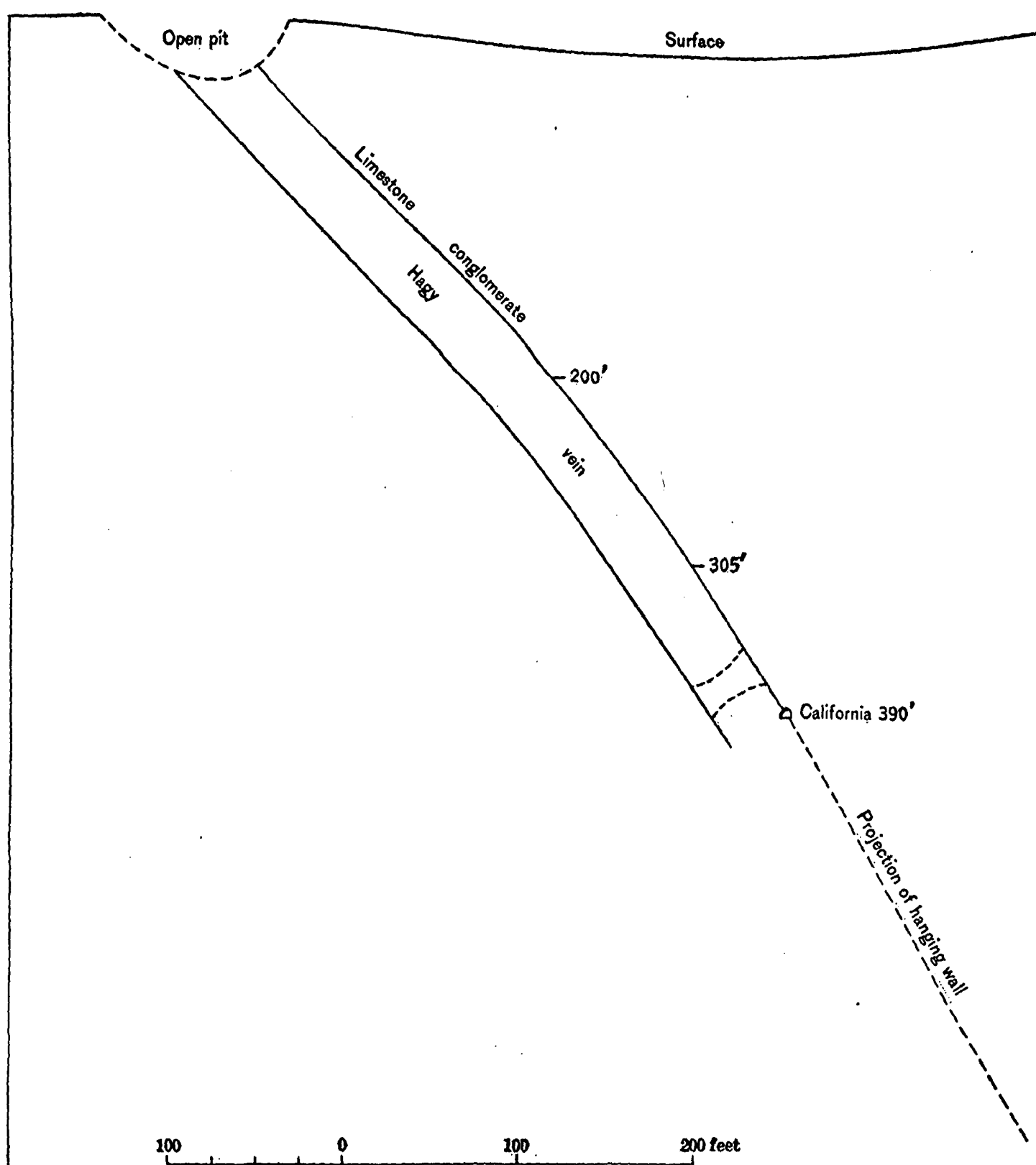

$\Delta \mathrm{W} .610^{\circ}$

CROSS SECTION AT BOYERTOWN MINES (ALONG LINE K-L, PL, $X$ ). 
it will drive to the southeast, thus opening a third level on this valuable ore tract. [See 552-foot level, $\mathrm{Pl}$. X.]

A crosscut was driven from the 474-foot level toward the southwest into the hill, but the ore was found to be cut off in this direction by the diorite dike which oitcrops on the north side of Gabel Hill.

\section{LATER DEVELOPMENTS.}

The descriptions which have been given include the tunnels and shafts opened before 1883. Between that year and 1893 the workings of the various mines were considerably extended. Gabel shaft No. 1 was carried to a depth of about 570 feet, and on the 552-foot level a crosscut was run to the Blue and Black veins, giving stoping ground of 9.8 feet vertically below the next level above. Gabel shaft No. 2 was sunk to a depth of 665 feet. The shaft encountered the Black vein at about 640 feet, but the thickness of the ore body can not be stated. The workings from the shaft comprise two short drifts in the ore body. The northerly drift, about 55 feet long, is connected by a raise with the 552-level of Gabel No. 1 mine. The southerly drift is 25 feet long and from its end a crosscut tunnel penetrates the foot wall. The length of this tunnel is about 360 feet. About 35 feet from its end short drifts, which extend to the right and left, are supposed to follow the hanging wall of the Blue vein. Unfortunately no person was found who had worked in this tunnel, and its depth below the surface is not accurately known. Between shaft No. 1 (where the ore was first cut at a depth of about 180 feet) and shaft No. 2 the Black vein had been proved as a continuous layer for about 800 feet in the direction of dip. On the trespass level the drifts in ore within the Gabel property were about 250 feet long, and from the Warwick shaft the vein had been followed for 400 feet before crossing the property line.

The Blue vein lies below the Black vein somewhat more than 100 feet, measured normal to the bedding, or from 160 feet to 325 feet measured along the various crosscuts. It has been mined on the dip to the height of about 375 feet and on the strike to a maximum length of about 250 feet. On the 640 -foot level neither vein had been fully developed when mining was suspended. To judge from the course of the Blue vein in the higher workings, it is not likely to extend more than a short distance into the Warwick plot. All of shaft No. 1 below the Blue vein-that is, below a level about 400 feet from the top-is supposed to be in diabase (greenstone of D'Invilliers's description), though no positive statement to this effect was made either by Willis or by D'Invilliers.

No information has been procured in regard to the behavior of the ore bodies in the southernmost workings of Gabel No. 1 mine; but the fact that none of the drifts were extended for more than 200 feet 
from the crosscut may indicate that both veins come to an edge in this ground. In view of the uncertainty which exists on this point it would be safer to lay out any exploration for the veins at lower levels southeast of the shaft rather than south or southwest.

In the Warwick mine two lifts were sunk after 1883 . On the 610foct level the vein was found to be double (as on the 555-foot level), and both the foot-wall and hanging-wall leads were developed by drifts extending southward nearly to the property line.

An extension of about 120 feet would connect the foot-wall gangway with the 640-foot level of the Gabel mine. On the 610 -foot level a crosscut 200 feet long which was run into the foot wall nearly to the property line failed to locate the Blue vein, but nothing is known concerning the rocks penetrated. Unless diabase was encountered it would seem to be worth while, in view of the present control of both the Gabel and Warwick tracts by the same company, to continue this tunnel to the diabase, for in the Gabel mine, at about the same elevation, the horizontal distance between the Black and Blue veins was about 325 feet. In the eastern drifts of Gabel No.' 1 mine the manner in which the Blue vein curves toward the north and the fact that the drift on the 552-foot level if continued in its course would pass nearly under the end of the drift on the 454-foot level suggest that in this ground the Blue vein stands very steeply.

In a search for the Hagy vein two tunnels were run into the hanging. wall on the 610-foot level about 100 feet east of the shaft. Though the vein was not located, it is probable that it may yet be discovered by extending the exploration toward the north or northwest. This point is referred to again on page 59 .

The workings. on the Warwick 683-foot level, so far as is shown on the map (Pl. X), comprise a gangway 200 feet long, apparently on the foot wall of the vein, and two crosscuts, one into the foot wall and the other started toward the hanging wall. No data have been procured concerning the ore body on this level, and the nature of the rock encountered in the lower part of the shaft is not known. It may be suggested that if the Warwick shaft penetrated any considerable mass of diabase there can be no further probability of encountering either the Blue vein or the Rhoades vein on the lowest level, as the foot wall of both is the Gabel Hill intrusive mass. On the other hand, if the main mass of diabase has not been encountered there is still a chance of finding ore by locating and exploring the diabase contact.

In the California mine the workings now reach a vertical depth of 390 feet, two levels having been opened below the 200-foot level, which was the lowest in 1883. Just beneath the old sump a body of ore was encountered which was known as ore No. 2. On the 305foot level, where the same bed was struck about 20 feet from the 


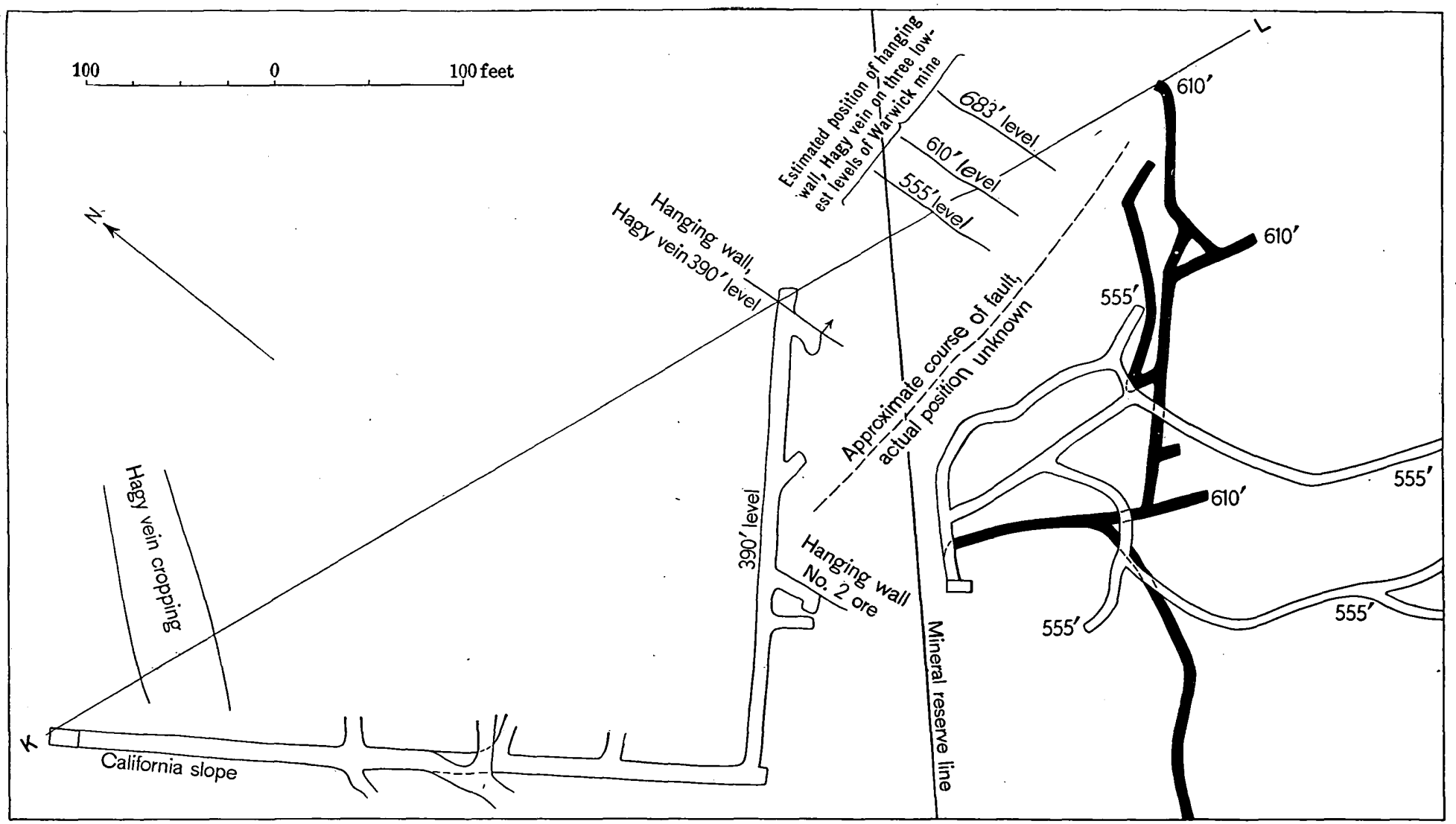

PLAN OF CALIFORNIA AND WARWICK MINES AT BOYERTOWN, PA., SHOWING POSITION OF FAULT. 
slope, it extends for about 30 feet along the drift and is reported to be 18 to 20 feet thick. On this level about 45 feet beyond ore No. 2 , or 95 feet distant from the slope, the Hagy vein was encountered. Along the hanging wall it was mined for 125 feet. On the 390 -foot level ore No. 2 was cut about 75 feet from the slope and it continued in the drift for about 30 feet, with a maximum thickness of about 20 feet. Fifty feet farther on the Hagy vein appears and, being cut diagonally, continues for about 90 feet in the drift. This vein has been stoped from the 390-foot level to the bottom of the Hagy pit, or about 500 feet along the dip.

In the California mine the southernmost workings in the 390 -foot level on ore No. 2 are about 60 feet distant from the Warwick shaft and about 30 feet higher than the 416-foot level of the latter mine on which the Warwick vein was first opened. The proximity of these workings leaves little doubt that ore No. 2 and the Warwick vein are parts of the same ore body, as has been commonly supposed by persons most familiar with these mines.

PRACTICAL CONCLUSIONS.

Facts are not at hand to warrant an unreserved statement of the relation existing between ore No. 2 and the Hagy body; at the same time, it is thought that they are probably parts of a single vein which has been separated by faulting. The existence of a fault is surmised from the knowledge that in the Warwick mine limestone conglomerate forms the hanging wall of the vein at least as deep as the 555foot level, whereas in the upper levels of the California mine the same rock lies above the Hagy vein. If, then, the Warwick vein holds its position just beneath the conglomerate as it extends upward into the California mine, and if the Hagy vein holds its position beneath the conglomerate as it extends downward from the 200 -foot level to the 390-foot level there can be no doubt that both the ore layer and the overlying conglomerate have been offset along a fault break. The same conclusion would follow if it were found that conglomerate forms the hanging wall both of ore No. 2 and of the Hagy vein on the 390-foot level of the California mine. The horizontal displacement along the fault appears to be about 125 feet (Pls. VIII and XVI).

On the assumption that there is a fault and that the Hagy vein continues to dip about $65^{\circ}$, as noted on the map (Pl. X) at the end of the 390-foot level, California mine, the positions of the foot wall on the 555-foot, 610-foot, and 683-foot levels will be approximately as shown by $\mathrm{Pl}$. XVI.

On the 390-foot level in the California mine, according to $\mathrm{Mr}$. Richards, exploration was carried in lean ore for 50 or 60 feet toward 
the north along the strike of the vein. This makes it appear that mineralization dies out in this direction. A similar decrease in values having been found in a 100-foot westerly drift from the middle slope, the intervening ground has been judged to be barren. Whether it is really so or not of course can not be decided without actual exploration, but the existence of a fault break or of several breaks between the workings of the California mine and those of the Phoenix mine on the East vein is strongly suggested by the relative positions and different strikes of the Hagy and East veins. A good idea of these features may be obtained from the plan giving the projected positions of the several veins on a level surface 400 feet below the top of Gabel No. 1 shaft (Pl. VIII). Mr. Richards states that on the lowest level of the workings on the East vein good ore continued east of the upper slope about 100 feet, beyond which lean ore was penetrated for perhaps 50 feet. On the middle level, 43 feet vertically above, mining was continued toward the east for 150 feet, and on the upper level, 43 feet higher, good ore was found for fully 500 feet. The total length of the ore body on the upper level was about 750 feet. Corresponding roughly with the bottom of the minable ore, which is found farther and farther west as depth is gained, the upper edge lies more than 100 feet east of the middle slope on the upper level, about 25 feet east on the middle level, and some distance west of the slope at the bottom of the mine. It is thus apparent that, in addition to its southeastern dip, the ore shoot pitches toward the south, and also that if this pitch continues the ore body must pass into the block of ground bounded by Third street, the mineral-reserve line, and the railroad. How far it may persist in this direction can not be suggested. It may or may not extend as far as the ore horizon remains unbroken.

It is strongly suspected, as already stated, that at least one displacement of the ore horizon-that is to say, the surface between the limy strata and the limestone conglomerate-exists between the middle slope and the workings of the Hagy vein of the California mine. Three faults with horizontal displacements equal to that of the fault supposed to exist between the Warwick and Hagy ore bodies would suffice to throw the ore horizon from the place it occupies in the California mine into the observed position of the East vein. (See fig. 7.) If the Hagy vein is ever found in the lower workings of the Warwick mine, further prospecting in the direction of the estimated downward extension of the East vein would seem warranted. The intervening block of ground may not contain workable ore near the surface, but is perhaps more likely to carry ore bodies as depth is gained, because the mineralizing waters which produced the ore are believed to have come from below. 
The chances of finding the Hagy and East veins above the lowest level of the Warwick mine are thought to fully warrant explorations along the lines of the foregoing suggestions, but the ground that offers the strongest inducement for exploration is that which lies beyond the Warwick and Gabel workings in the direction of the dip of the Warwick ore body. No extended argument is needed to show the advisability of testing the further persistence of an ore body like the Warwick or Black vein, which has been followed along its course almost continuously (though swelling and pinching) for 1,000 feet and along its dip for 800 feet, with no signs of failure in the lowest levels that have been opened. The map and cross sections (Pls. $\mathrm{X}-\mathrm{XV}$ ) which accompany this report afford adequate data for laying

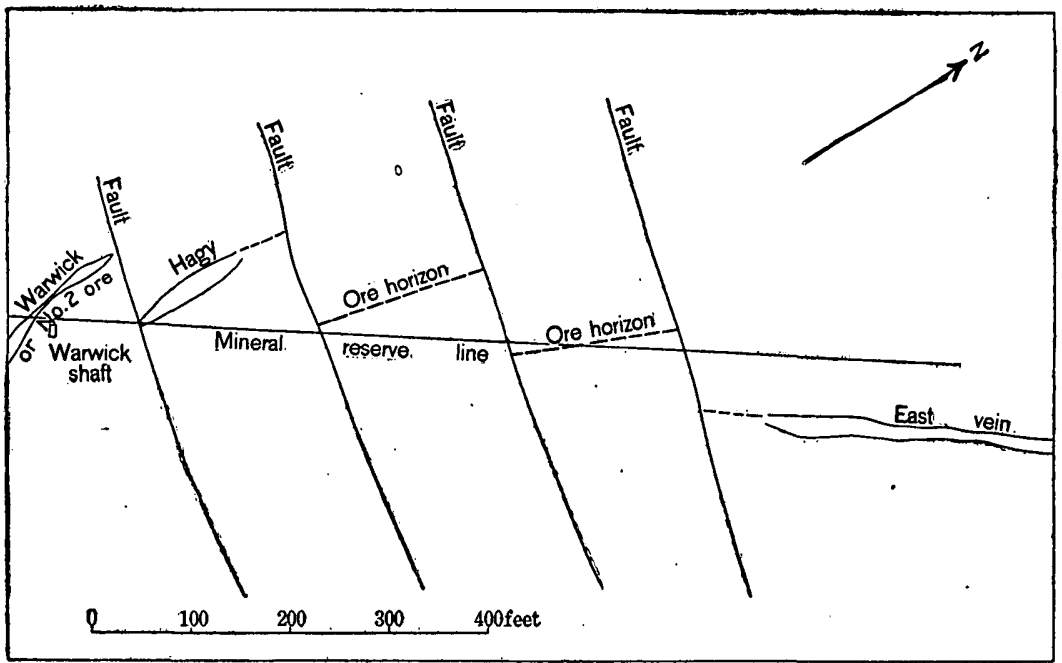

FIG. 7.-Ideal sketch showing possible type of structure in ground between Hagy vein and East vein. Datum of plan, 400 feet below top of Gabel No. 1 shaft.

out an advantageous plan of prospecting the veins by means of the diamond drill.

The theory which has been developed concerning the origin of the Boyertown ore bodies is based on the analogies between these deposits and those of similar character at other places in the State, each of which exhibits a close dependence on adjacent bodies of intrusive diabase. It is noteworthy that all the ore bodies except the East vein lie just beyond the termination of the diabase sill which occurs along the northwest side of Gabel Hill. Apparently underground the sill dips with the bedding of the invaded rock and the edge which it presents toward the north pitches steeply in such a direction that it passes beneath the Warwick and Gabel workings. The Blue vein in the Gabel mine appears to follow the upper surface of the sill, but the Rhoades vein seems to lie against its blunt edge. In the 
Gabel mine more than 100 feet of limy strata lie between the diabase and the conglomerate which caps the Black vein; but all indications on the surface favor the conclusion that the conglomerate extends northward almost if not actually to the walls of the diabase. As in the mine it appears that the diabase follows the stratification of the limy beds, the near approach or actual contact of the conglomerate and the diabase at the surface signifies one of two things-either that the intrusive mass cuts across the stratification above the point where the contact is penetrated by Gabel No. 1 shaft, or that the parallelism between the stratification of the Paleozoic and Mesozoic rocks, which apparently exists elsewhere in the mine, does not hold in this place. A plausible suggestion of what the relations may be in depth is

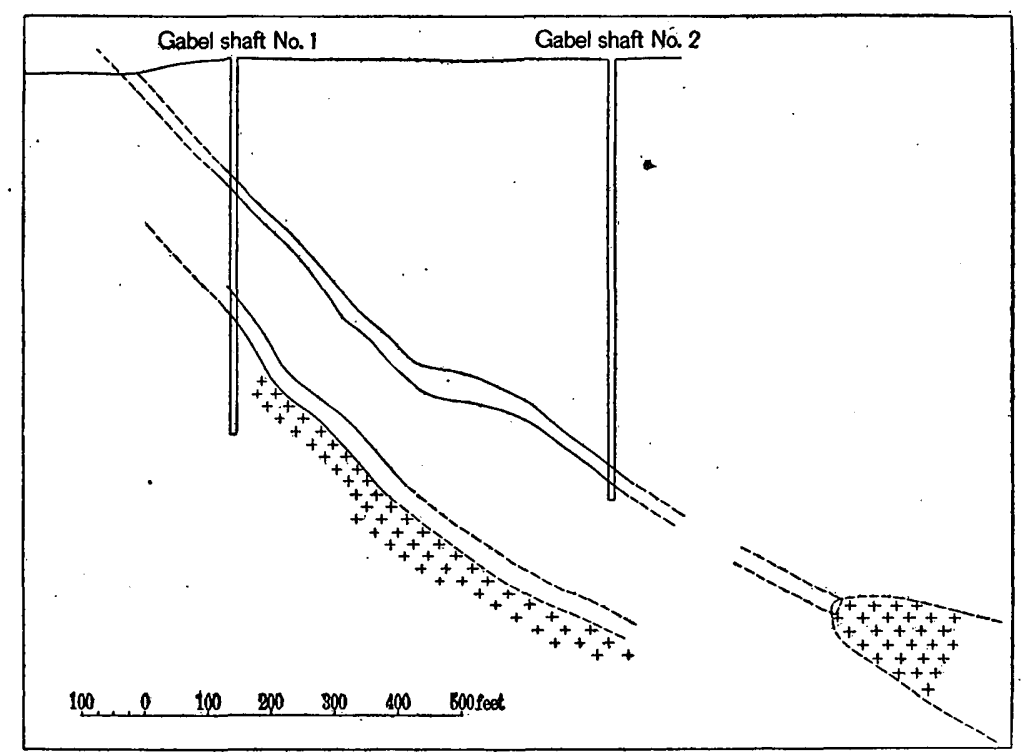

FIG. 8.- Sketch section illustrating possible relation of Black vein to buried edge of a diabase sill at Gabel mines.

illustrated in fig. 8. The presence of several sills south of Boyertown, as shown on the sketch map, the manner in which these sills terminate, and the probable existence of an underlay of diabase beneath the structural basin which has been described all suggest the validity of the assumption that one or more buried sills exist in the region southeast and east of the Boyertown mines.

The emergence of a minor intrusion of diabase near West Swamp Creek, 1 mile northeast of New Berlinville, and of a great mass east of Bechtelsville suggest that the edges of the sills representing the upward limit of intrusion on the northwest side of the synclinal basin probably lie at no great depth and not very far back (southeast) of the boundary between the Mesozoic area and that occupied by the 
older formations. If the presence of the buried sills in this vicinity were known to be a fact, and if the place could be determined where any one of them penetrates strata corresponding to those in which the Boyertown deposits occur, the existence of a series of iron-ore deposits in the limy strata near the diabase might be suggested. The absence of knowledge on these two points leaves the whole question in the light of a speculation, with the hazards rather too great to justify recommending the expenditure which would be required to make a practical test. The imaginary position of the

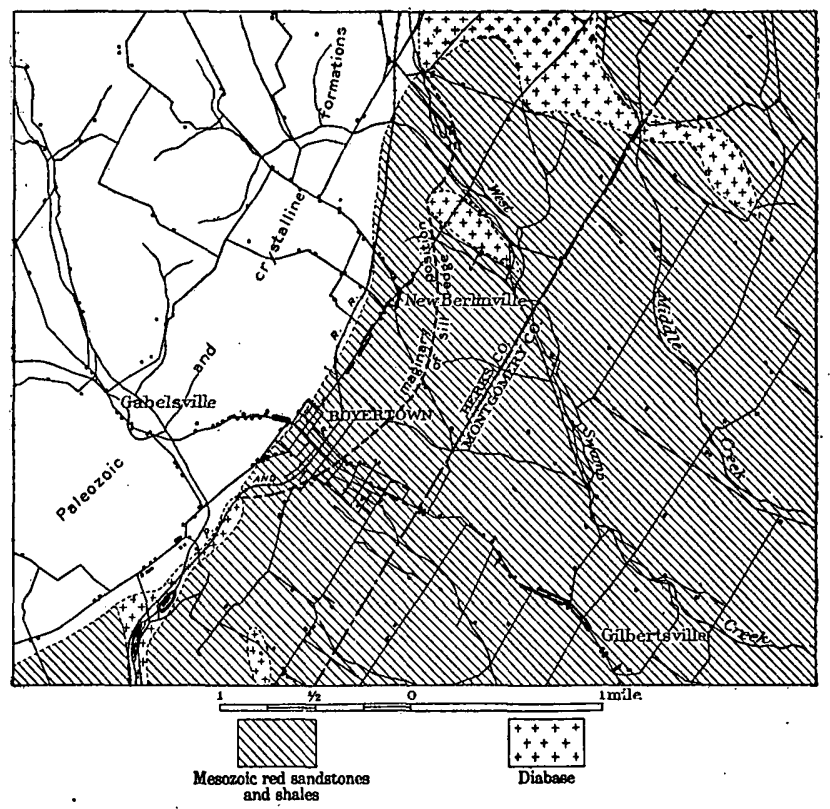

FrG. 9.-Geologic sketch map of vicinity of Boyertown, showing imaginary position of edge of buried sill.

upper edge of the supposed sill is shown in plan on the sketch map, fig. 9 .

\section{DEPOSITS SOUTHWEST OF BOYERTOWN.}

South of the Boyertown mines the northwest slope of Gabel Hill is formed by diabase, the hill itself and the connecting ridge for a mile or more toward the south being formed by baked and indurated shales and sandstones. At the surface this mass of diabase ends as an apparently blunt wedge south of the ground in which the ore deposits have been found, and as nearly as can be determined it comes to the surface just at the base of the Mesozoic beds where they overlap on the ore-bearing strata. In this position the diabase, having the form of a sill, extends for three-fourths of a mile southwestward and 
then, turning down the valley of Ironstone Creek, cuts back into the Mesozoic area. The western edge of this sill has not been seen at any place because it comes to the surface beneath a mantle of loose débris, but its eastern contact was encountered at the old Brower iron mine on the hill slope opposite the upper end of Wren's ice pond, about half a mile southwest of the Rhoades mine. The Brower ore at this place was discovered in a post hole.

Richard Richards, of Boyertown, who had charge of this property in 1857 and 1858, states that he extracted more than 2,000 tons of magnetite ore from an irregular layer having a northeast-southwest strike, a dip of $35^{\circ}$ or $40^{\circ}$ SE., and a maximum thickness of about 8 feet. The mine was worked by means of a tunnel and two shafts, and ore was stoped from two levels to a depth of about 70 feet and to a length on the strike of about 50 feet. Examination of the locality shows that the ore layer occurred very near if not exactly in contact with the upper side of the diabase sill, under a hanging wall of flinty baked shale or sandstone. Taken by itself the occurrence of ore at this place is an all but evident instance of ore segregation during igneous or socalled contact metamorphism, and considered in the light of the many like deposits closely associated with intrusive diabase at other places it must be accepted as a deposit of this variety.

About 300 yards southwest of the Brower mine, back of the J. Wren house, a short tunnel with its mouth in diabase was started toward the contact, but no information has been obtained concerning what was found at this place, nor concerning a shaft lying between the Wren tunnel and the Brower mine, shown on the topographic map of the Second Geological Survey of Pennsylvania.

About one-fourth mile southwest of the Rhoades mine, on the hill slope about 50 feet above the level of the railroad track, a shaft (known as the Rhoades and Grim shaft) has been sunk to a depth of 40 or 50 feet, to judge from the material on the dump. Nothing but diabase seems to have been encountered at this place. East and somewhat north of this shaft a tunnel of unknown length was run into Gabel Hill, but no person was found having any knowledge of this work. The mouth of the tunnel is situated very near the eastern or upper edge of the diabase sill, and it seems that Mesozoic strata must have been penetrated.

It is not at all unlikely that other masses of ore like those of the Brower mine exist along the east contact of the sill, but as no limy strata are known to occur on the upper side of the diabase, this ground is not regarded as offering much inducement for prospecting. West of the diabase, conditions are probably more favorable, on the supposition that the strata which carry the Boyertown veins are here in contact with the under side of the sill, but the valley of Ironstone Creek is not a favorable place for making excavations, and it seems 
that any exploration of the under side of the diabase should be undertaken by means of the diamond drill.

\section{DEPOSITS NORTH OF BOYERTOWN.}

About 2 miles north by northeast of Boyertown there has been some exploration for iron ore on the south side of the group of diabase hills southeast of Bechtelsville. The position of two shafts is shown on the topographic map of Berks County, issued by the Second Geological Survey of Pennsylvania, though no essential data are given in the Berks County report beyond the statement that some excellent

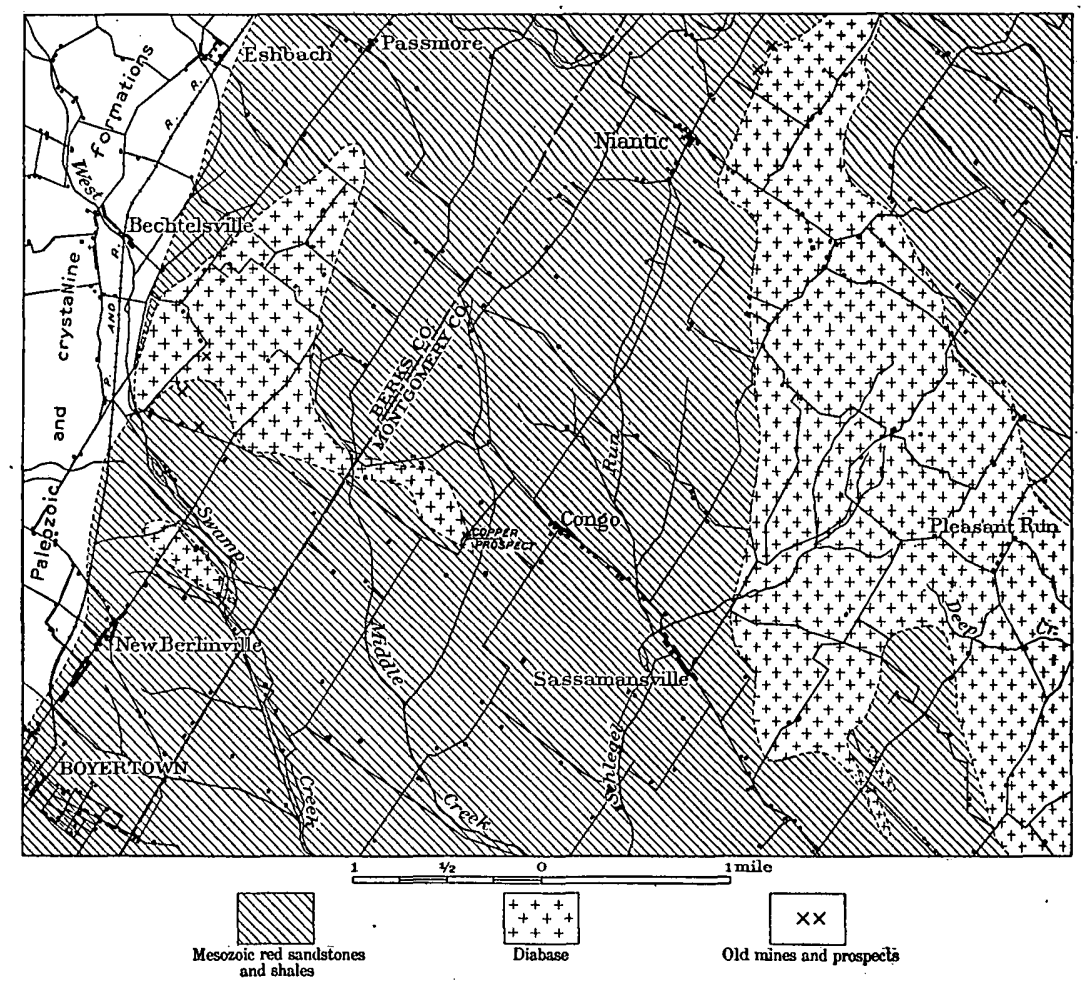

FI G. 10.-Geologic sketch map of region northeast of Boyertown.

ore was taken from an opening known as the Gilbert shaft. The shafts mentioned were not found during the present investigation, but from their indicated position they are situated within Mesozoic strata, which come up onto the diabase rock from the south.

The diabase covers a roughly triangular area of nearly 2 square miles, which lies between West Swamp Creek and a tributary known as Middle Creek. From the southeast corner of this area an arm extends for about $1 \frac{1}{2}$ miles toward the southeast. The mass of diabase is nearly surrounded by Mesozoic strata, which appear to lap onto it from the east and from the south. (See fig. 10.) On the northwest 
the structural relations are obscure, but from the rock fragments scattered over the fields the Mesozoic rocks are known to be present along the base of the hill above the wagon road to a point within one-fourth mile of the bridge across West Swamp Creek. Near the turn in the road, a short distance northeast of this bridge, blue Paleozoic limestones are exposed, and above them baked shales, which may belong to the Mesozoic. This shale seems to dip toward the hill at a low angle, as if it would pass beneath the mass of diabase which outcrops a short distance up the slope. The blue limestone is not metamorphosed to any marked degree.

On every side of the diabase the Mesozoic rocks, including shale, sandstone, and limestone conglomerate, have been considerably baked, and this induration extends in places as far as one-half mile from the contact. Loose fragments of limestone conglomerate containing abundant spangles of hematite may be found at several places along the ridge east of Middle Creek, and similar material is abundant on the hill slope about 1 mile southeast of Eshbach. On the south side of the diabase hills both specular hematite and magnetite were noted in material revealed in a cutting along the east-west road a few hundred yards west of the crossroads $1 \frac{1}{4}$ miles northeast of New Berlinville. This locality is near one of the old prospecting shafts mentioned above.

Although the presence of hematite in the baked rocks which surround the diabase shows that certain conditions favorable for the formation of ore existed, it does not seem that any large bodies of ore are likely to be encountered in the Mesozoic strata. The exposures are not sufficient to indicate how much limestone conglomerate exists in the neighborhood, but it is probably not present in any such amount as at Dillsburg, York County, where magnetite ore deposits are associated with beds of this rock in the vicinity of diabase intrusions.

Near the diabase there is only one exposure of the Paleozoic limestone which is known to occupy the valley lying west of the diabase hills, so that almost nothing is known of the structural relations of this rock to the Mesozoic strata and to the diabase. It is probable, however, that the limestones are here overlapped by the Mesozoic strata in much the same way as in the vicinity of the Boyertown mines, and if this is so there is a possibility that the ore bodies may exist in depth beneath the Mesozoic rocks which occur west of the diabase mass. Though this point could be readily tested by a series of drill holes along the western portion of the diabase area, such exploration would be regarded as a hazardous project from a practical standpoint.

Iron ore is said to have been extracted from workings known as the Fegley mine, situated well within the diabase area on the north 
side of the little brook about one-fourth mile north of the Gilbert shaft. A suggestion concerning the manner in which the ore occurs in this place was obtained from material on the dump at the tunnel mouth. A large fragment of diabase was found, on one side of which there was a coating of ore 1 inch thick composed of crystalline magnetite intergrown with a minor amount of feldspar. Appearances indicate that the magnetite was segregated in a crevice traversing the diabase. There is no sharp division between the rock and the ore, a fact which suggests that the magnetite and accompanying feldspar may have been deposited by vaporous solutions derived from the deeper-seated part of the diabase mass shortly after the period of intrusion.

In many places the diabase intrusions in the Mesozoic area contain very considerable amounts of magnetite as a mineral constituent, but this is the only place that has come to the writer's attention where magnetite has been found segregated in a definite vein inclosed by the igneous rock. This occurrence has a bearing on the general problem of the genesis of deposits of the Cornwall type, affording good evidence that the diabase rock could have been the actual source of the ore-forming solutions as well as of the energy which caused the circulation of the mineralizing waters. Elsewhere, though the influence of the diabase intrusions is everywhere noteworthy, it has not been possible to show definitely that the solutions have emanated from the intrusive rock.

A shallow pit has been sunk in search of copper ore in a road-metal quarry beside the wagon road half a mile west of Congo post-office, near the end of the arm of diabase which extends toward the southwest from the main triangular area. In the walls of this pit may be seen a veinlet about an inch wide, composed mainly of hornblende and feldspar containing scattered bunches of chalcopyrite. The hornblende of the vein appears to have grown out from the walls of a crevice, and the material of the vein is thus closely knit to that of the inclosing rock, as in the magnetite vein described above. It is suggested that this veinlet was formed in a manner similar to that suggested for the magnetite vein. In a recent paper on the copper deposits of New Jersey by J. V. Lewis ${ }^{a}$ the source of this metal is believed to have been the diabase intrusions which in each place are associated with the ore occurrence.

\section{JONES MINE.}

The Jones mine, also known as the Warwick mine because it was formerly worked by the Warwick Iron Company, is situated about three-fourths of a mile east of Joanna station and $1 \frac{1}{4}$ miles northwest

a Copper deposits of the New Jersey Triassic: Econ. Geology, vol. 2, 1907, pp. 242-257. $54370-$ Bull, 359-08- -5 
of Elverson, on the Wilmington division of the Philadelphia and Reading Railroad. (See Pl. XVII.) This mine is in Berks County, about 4 miles west-northwest of the Warwick mines in Chester County. Part of the description of the Jones mine by H. D. Rogers is here given: ${ }^{a}$

The chief mine is an open excavation covering rather more than 5 acres, and there is another to the south of it covering about 1 acre [Kinuey mine]. Magnesian limestone bounds the ore on the northern edge of the principal excavation. Here there is a mine shaft 180 feet deep $* * *$. The shaft enters the limestone at a depth of 50 feet, and a boring 20 feet from the bottom of the shaft is still in this rock.

A dike of trap rock cuts the ore-bearing strata near the southern side of the pit and produces. phenomena precisely identical with those caused by the trap dikes in the Cornwall-Lebanon mines, converting the ore to a more highly crystalline form and endowing it partially with magnetism. As in every such instance, the ore is richest and purest adjacent to the trap rock. This is equally the case in the southern or smaller mine. The strata dip N. $30^{\circ} \mathrm{W}$. at about $20^{\circ}$; and in the northern bank of the large mine we may perceive the Auroral limestone regularly overlying the upper beds of the Primal state, containing or consișting of the ore. *** In this mine, as in that of Cornwall and that'of Lebanon, some of the ore contains a small amount of copper.

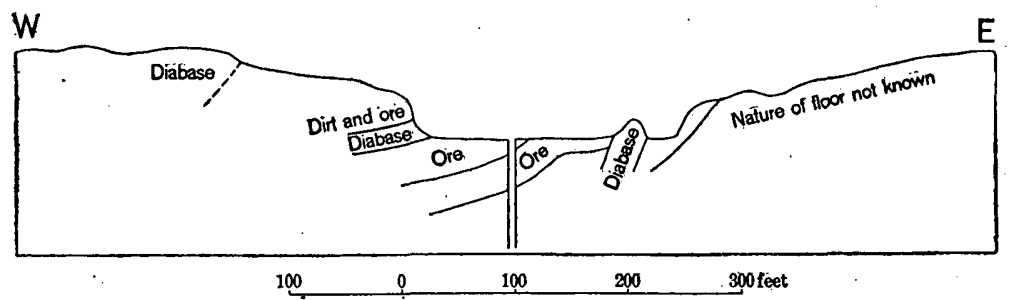

FIG. 11.-East-west structure section, Jones mine (along line $A-B, \mathrm{Pl}$. XVIII).

A large-scale topographic map of the vicinity of the mines by J. H. Harden (reproduced here as Pl. XVIII) accompanies the report by D'Invilliers on the geology of Berks County, but no description of the mine is given in the text. However, something of the geology and structure of the mines is indicated in cross sections which accompany the map. These data have been used in constructing the revised cross sections here given (figs. 11, 12, and 13).

The Jones mine and the smaller Kinney mine adjacent lie in the isolated area of Paleozoic limy strata, which are supposed to belong near the base of limestone "No. II" of the Pennsylvania section. As at Boyertown and Cornwall, there is apparently interbedding of limestone and limy shale, the latter being largely changed to ore, while the former exhibits a very moderate degree of metamorphism. Though the pit is now flooded, it is known from dips recorded on the Harden map that in the Jones workings the ore strata are considerably con- 


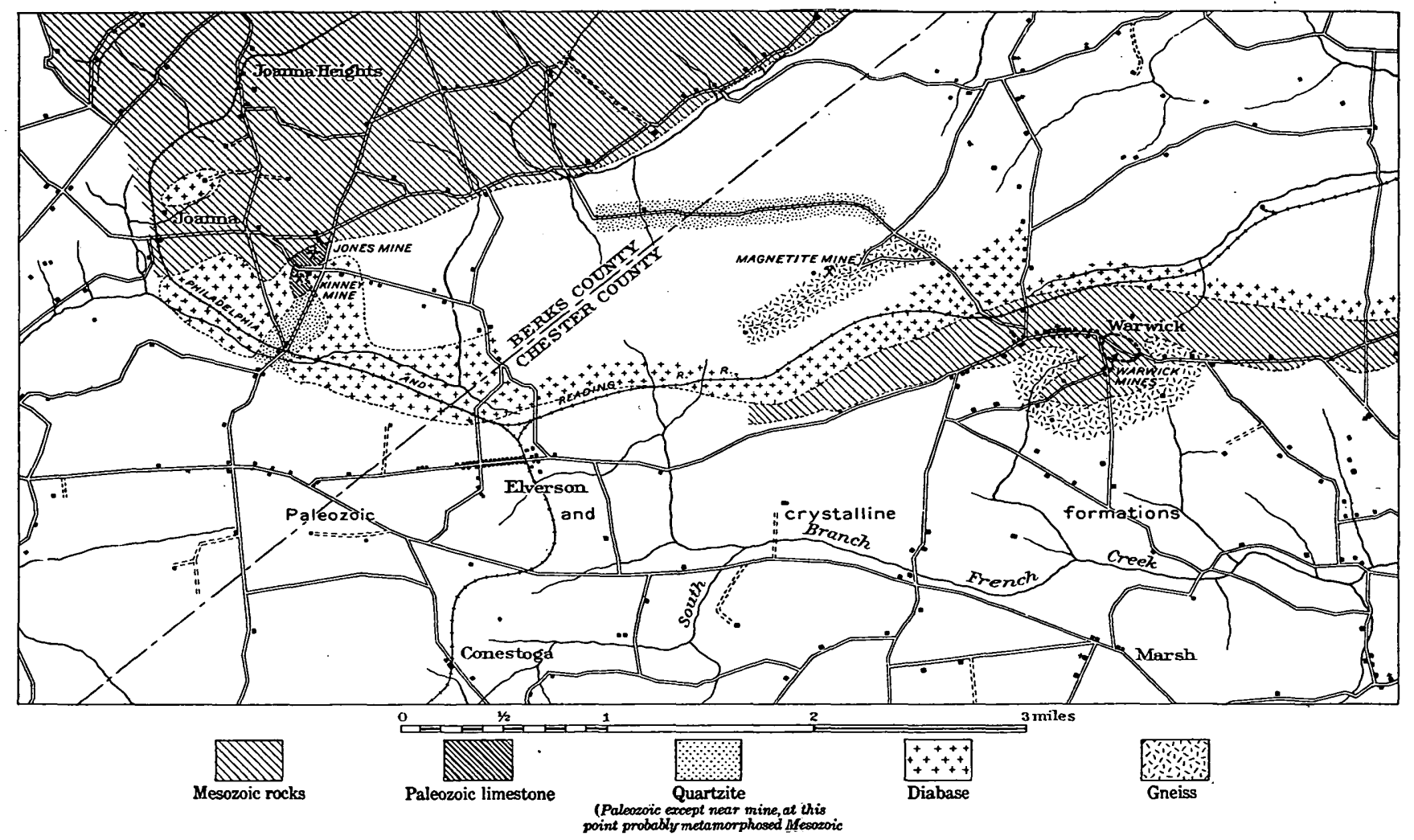

SKETCH MAP SHOWING GEOLOGY IN VICINITY OF JONES AND WARWICK MINES, BERKS AND CHESTER COUNTIES, PA. 
torted, the general direction of dip, however, being toward the west-northwest. In the northern pit the ore dips $16^{\circ} \mathrm{N} .55^{\circ} \mathrm{W}$. "Above the ore is a limestone bed conformable to it, about 12 to 15 feet thick, and above that still is a conformable lightgreen earthy shale." $a$

The ore-bearing strata are overlapped on the north by reddish Mesozoic conglomerate, containing large quartzite pebbles. East of the large mine the nature of the bed rock can not be determined, but presumably the limy strata run out for several miles in this direction. On the State Survey geologic map of Berks County the "No. II " limestone is represented as a narrow strip extending through the Jones mine toward the eastnortheast as far as Hopewell furnace, and though no outcrops are to be found it is very likely that these strata underlie the accumulation of surface débris along the topographic depression which separates the red conglomerate and sandstone hills on the north from the quartzite hills on the south.

Two bodies of diabase occur on the south side of the Jones pit and are exposed along the edge of the excavation. Between them are limy strata in the southwest corner of the pit, and these beds probably extend through to the Kinney mine. South of the Kinney pit quartzite fragments occur in the soil, and near the railroad crossing this rock may be seen in place. It is not known whether the quartzite belongs to the Mesozoic or to the Paleozoic "No. I" sandstone. The area which it occupies is limited on the west and east by the masses of diabase. The western mass is exposed along the railroad for about one-half mile; the other may be traced eastward to the falls of French Creek and for several miles beyond. The mass of diabase represented on the Berks County map just north of Joanna station was not visited by the writer. Several minor masses of diabase, dividing the ore, were encountered in the mine workings. The sketch map. (Pl. XVII) shows the distribution of the various rocks in the vicinity of the Jones and Warwick mines.

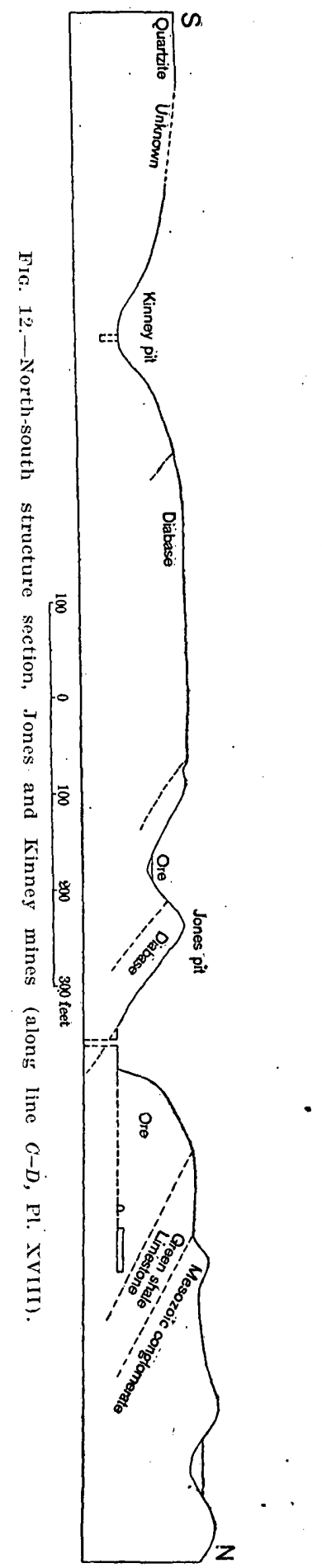


The iron minerals of the Jones ore are magnetite and pyrite, and some of the ore contains chalcopyrite. In the richer material the magnetite and pyrite occur in more or less crystalline form, accompanied by calcite or dolomite, the whole forming a rather granular aggregate. Such ore does not betray its origin; but lean material, of which there is a great amount on the old dumps, shows clearly that the iron minerals have been formed by a chemical substitution or replacement of limy strata. Blocks may be seen showing all degrees of replacement and still retaining their stratification. Brecciation and cross veining, which are noteworthy features at Cornwall, are not observed in the material from the Jones mine. As at Cornwall, chlorite is an abundant mineral in the waste, but only minor amounts of this mineral occur in the usable ore. A few blocks of limestone containing small garnets were noted.

The important rôle of the intrusive diabase as an element in the local geology is shown by the extent of the rocks indicated on the geologic sketch map (Pl. XVII). The writer believes that the segregation of the ore resulted from the intrusion of this rock, though evidence sufficient to establish this theory has not been found. That

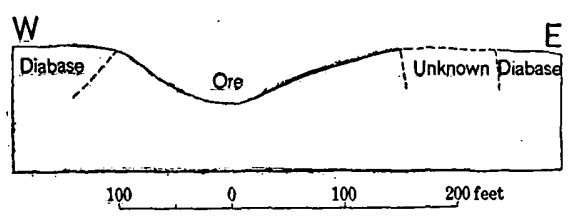

Fig. 13.-East-west structure section, Kinney mine (along line $E-F$, Pl. XVIII). ore minerals were being deposited after the diabase had been injected is indicated by the presence of magnetite, pyrite, calcite, and chlorite in cracks in the igneous rock and entirely surrounding fragments

of it. Blocks showing these relations, which presumably came from one of the minor masses of diabase encountered in the workings, were found near the engine house, on the north side of the Jones mine.

From existing descriptions it appears that the overlapping Mesozoic strata are separated from the ore body by barren shale and limestone, a relation which makes it difficult to.believe that the leaching of these ferruginous sediments could have furnished the iron for this large ore body and which leaves the way open for the suggestion that the diabase was the source of the mineralizing waters and of the iron that they contained.

The discussion of the possible occurrence of other ore deposits in the vicinity will be deferred until the detailed geologic map of the district is available. Professor Bascom, of Bryn Mawr College, is now engaged in studying the geology of the Honeybrook quadrangle, in which the mines are situated.

The following note is copied from Frazer: ${ }^{a}$

On the lands of the Warwick reserve, 2 miles southeast of the Joanna furnace and about $1 \frac{1}{2}$ miles east of Morgantown and $\frac{1}{2}$ mile south of the narrow belt of

a Frazer, Persifor, jr., Second Geol. Survey Pennsylvania, Rept, CCC, 1877, p. 237. 


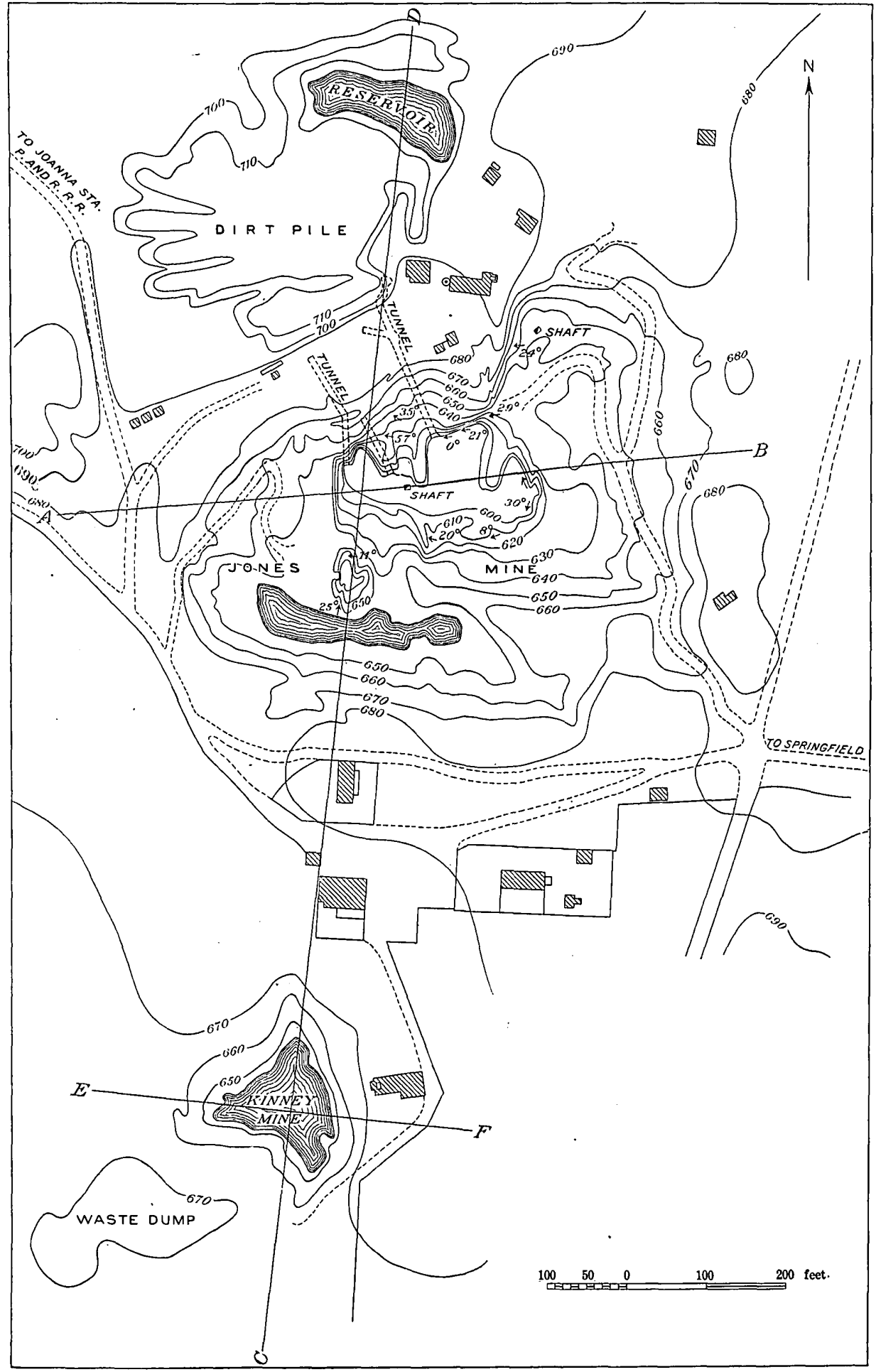

TOPOGRAPHIC MAP OF VICINITY OF JONES AND KINNEY MINES, BERKS COUNTY. PA. 
limestone which leaves the large Lancaster limestone tract and passes through Morgantown, *** in Berks County, is an exploitation for ore. *** The material thrown out of the pit appears to be an altered mud rock, alongside of which occurs ore very like that of Cornwall and some of that from Dillsburg.

\section{WARWICK MINE.}

The old workings of the Chester County Warwick mine are situated just east of Warwick, formerly known as St. Marys. (See Pl. XVII.) The deposit appears to have been nearly exhausted prior to 1875 , although there was some mining as late as 1882 . Little can be made out by an examination of the ground at the present time, but such features as can be observed correspond with the following description published by H. D. Rogers in 1858: ${ }^{a}$

This extensive and interesting body of iron ore, situated just southeast of St. Mary's Episcopal Church, is in reality not a genuine lode or igneous intrusive vein, though the ore derives some of its characters from intrusive igneous action, but it is a bed or deposit at the base or very near the base of the middle secondary red sandstone, which here laps upon the gneiss. The explored extent of this bed, hitherto penetrated only near its outcrop, or where the overlying

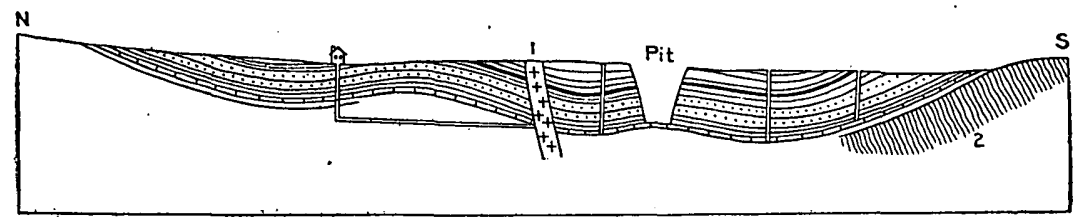

FIG: 14.-Structure section at Warwick mine, Chester County. After H. D. Rogers. 1, Diabase ; 2 , gneiss.

strata are shallow, is already very great, amounting to many acres. The ore deposit observes everywhere a very gentle dip, and seems to undulate in two or three waves across the tract which includes it. A somewhat conspicuous anticlinal change in the dip occurs to the south and southwest of the present main engine shaft by which the mines are dried, and there is every indication that the ore basins are both south and north of this saddle. Though the basin to the south of it is intersected, and the ore in one place cut off or thrown out to the surface by the intrusion of a wide dike of trap rock, there is strong reason to infer that the ore occupies a comparatively wide though perhaps shallow basin, north and northeast of the engine shaft [fig. 14].

Besides this intrusion of trap, there seems to exist here injections of serpentine and other mineral matters, and at one point, just by the southwest margin of the ore bed, there exists a very singular intrusion of mineral matter penetrating the ore and altering, in a remarkable manner, the conglomeratic layers which here constitute the southeast border of the red sandstone formation. This rock is greatly baked and changed in aspect, includes numerous spheroidal bunches of segregated crystalline mineral matters (some of them in the form of hollow geodes), and is intersected besides with numerous strings, or little veius. In these spheroidal nests oceur beautiful linings of crystallized epidote. and other minerals, and bunches of large crystals of the fine variety of garnet called melenite. The list of the minerals occurring here is not extensive. The 
conditions under which they present themselves are such as strongly to impress the geological observer with the notion of their having been introduced chiefly in a vaporous state, or by sublimation, for in many of these hollow spheroids we can detect no connection whatever between the interior or even the exterior walls of the geodes and any external veins or filaments of injected matter, such as any other theory would demand for the introduction of the materials of the crystalline minerals here so curiously insulated.

The bed of iron ore for which this locality is chiefly noted is of very variable thickness, fluctuating from 1 or 2 to 9 or even 17 feet. As illustrating the general levelness of this undulating deposit, it may be stated that in no place has it been required to sink deeper than about 60 feet to reach the ore, while generally the covering is so thin that the ore is conveniently procured by merely stripping oft a thickness of a few feet or yards of loose disintegrated rock. The average richness of this ore may be stated at about 45 per cent of metallic iron, though much of it exceels 50 per cent. It is somewhat sulphurous; and when care is not employed in selecting it for smelting, and in the after processes, it tends to produce a hot-short or red-short iron, but when carefully manufactured it yields an excellent metal. The annual product of the Warwick iron mines for fifteen years was not less than 4,000 tons, and the average yield. for the past twenty years has been 6,000 tons. In the year 1853 the amount mined reached 12,000 tons. These ore pits have been wrought for the last one hundred and twenty years, and there would seem to be at present really more ore within sight than there has ever been before at any one time. The present average cost of mining this ore is about $\$ 1.50$ per ton.

This ore is intermediate in its physical characters and aspect between the true brown hematite and the magnetic oxide of iron. As, on the view of its having been originally hematite but subsequently altered by igneous action, we might naturally anticipate, those portions of it which have undergone the highest degree of metamorphic influence are of a gray color, quite crystalline, and partially endowed with magnetic force, whereas the less altered parts are nearly. in the condition of a compact, closely cemented hematite. Minutely interstrati. fied with this ore there occurs more or less earthy matter, apparently lamina of indurated slate or shale; and when the layers of this rock are thick, and they disperse the ore, they interfere materially with the economical prosecution of the nine. This slaty or eartby matter tends, furthermore, by intimately mixing itself in with the finer granular ore, seriously to reduce the richness of the mingled mass in iron.

Specimens of the metamorphosed conglomerate described by Rogers may be found in the old mine pits. Green hornblende and brown garnet, calcite, pyrite, specular hematite, and magnetite are among the secondary minerals observed. Epidote was not noted. No geologist familiar with the common metamorphic alterations of sedimentary rocks adjacent to intrusive igneous masses can see this material without regarding it as a product of contact metamorphism involving the action of heated water. In the writer's opinion the features of the ore specimens which have been examined do not suggest that the magnetite of the Warwick deposit has been produced from brown hematite by heat metamorphism, as proposed by Rogers, but it seems that hematite, magnetite, and pyrite must have been introduced into their present situation and must have been formed contemporaneously. 
In conformity with the general theory concerning the origin of other deposits of the Cornwall type, it is suggested that the ore minerals were introduced by 'solutions sent into circulation by the intrusive diabase that occurs north of the mines. This view is justified by the baked condition of the Mesozoic strata throughout the strip whick lies south of the diabase mass and by the observed alteration of the conglomerate rock, so well described by Rogers. There is no evidence to show whether the iron was leached out of the Mesozoic strata or was furnished by the igneous rock.

The geologic relations observed at the Warwick mines continue for some distance both east and west. It is thought not improbable that similar ore deposits may exist at other points, between the east-west mass of diabase and the south edge of the Mesozoic strip which marks the overlap of the sandstone upon the ancient gneisses. Bodies of iron ore may lie in a position similar to that of the Warwick deposit and still not extend far enough south to have been brought to light along the edge of the Mesozoic strip. If erosion had been only slightly less than what is actually observed in the neighborhood of. the old mines the edge of the ore deposit would not have been stripped of its cover and would not have been discovered except by some chance excavation of considerable depth. On the other hand, the removal of a little more cover elsewhere along the line of overlap might have revealed deposits similarly situated, of which, under existing conditions, there are no surface indications. Although it is regarded as possible that systematic drilling might lead to the discovery of new ore deposits in the ground indicated, the undertaking of such extensive explorations as would be required can hardly be recommended as a business venture at the present time.

About $2 \frac{1}{2}$ miles east of the Warwick mines and just north of Knauertown indications of iron ore were prospected many years ago. The geologic position is identical with that of the Warwick deposit. On the basis of the theory that the mass of diabase which lies north of this place has been the inciting cause of the deposition of iron minerals, it is not unreasonable to expect that these indications may lead to a better deposit of ore at a greater depth beneath the hill.

\section{YORK COUN'TY DEPOSITS.}

\section{GENERAL STATEMENT.}

Iron ores like those of the Cornwall mines occur at several localities in northern York County. The principal group of mines is situated about 1 mile east of Dillsburg, and a second smaller group is located just south of Yellow Breeches Creek near Grantham crossing, on the Philadelphia and Reading Railroad. Specular hematite with some associated magnetite has been worked at Minebank schoolhouse, 
about 2 miles southwest of Wellsville, and minor pockets and indications of ore have been found at various other localities. Most of these occurrences had been discovered prior to 1873 and are described or mentioned in Report CC of the Second Geological Survey of Pennsylvania ${ }^{a}$ and in the Annual Report for $1886 .{ }^{b}$

In 1907, when the writer visited the field, no mining was being done, so that such data as could be collected concerning these interesting deposits have been procured from examinations of the surface and from conversation with persons familiar with the underground operations. Since the publication of the reports mentioned above only two new mines have been opened, but considerable ore has been taken from several of the old ones.

Two opinions have been expressed in published descriptions regarding the geologic position of the Dillsburg deposits. They have been held on the one hand to lie in Mesozoic rocks and on the other to occur in Paleozoic strata, as at Cornwall. Detailed study of the general region now shows that all the deposits are inclosed by the younger set of rocks, as stated by D'Invilliers.

The Grantham mines lie very near the edge of the Mesozoic area; those of the Dillsburg group are situated from $1 \frac{1}{2}$ to $2 \frac{1}{2}$ miles within the northwest boundary, and the mine southwest of Wellsville lies $6 \frac{1}{2}$ miles within the Mesozoic belt. (See Pl. XIX.) No bodies of ore and no strong indications of ore occurrence have been found except where the strata have been greatly metamorphosed or baked in proximity to intrusive masses of diabase. This association points definitely, as do all other occurrences of iron ore of the Cornwall type, to the belief that the ores are connected in origin with the intrusion of the diabase. However, the mere presence of diabase in a locality is by no means sufficient to insure the presence of ore near by; otherwise, York County would be unsurpassed as an ore field because of the great extent of the diabase masses within her borders. The scattered or limited occurrence of ore deposits points to a second condition as essential to the formation of ore, and it is believed that this condition is the presence of calcareous (or lime-bearing) rocks in the vicinity of intrusive masses of diabase. In all the more important mines of the Dillsburg group and at Grantham beds of limestone conglomerate are found in the workings. At Minebank, also, crystallized limestone is to be found in the mine waste. At Dillsburg many pockets of ore which were mined out years ago and one bed continuous for nearly 500 feet at the surface (McCormick long cut) appear to have been inclosed in baked sandstone. Though there is now no evidence that limestone occurs in these workings, it is possible that the masses of

${ }^{a}$ Frazer, Persifor, jr., Report of progress in the counties of York, Adams, CumberIand, and Franklin. 1877, pp. 201--289.

'Ann. Rept. Geol. Survey Pennsylvania for 1886, pt. 4, 1887, pp. 1501-1514. 

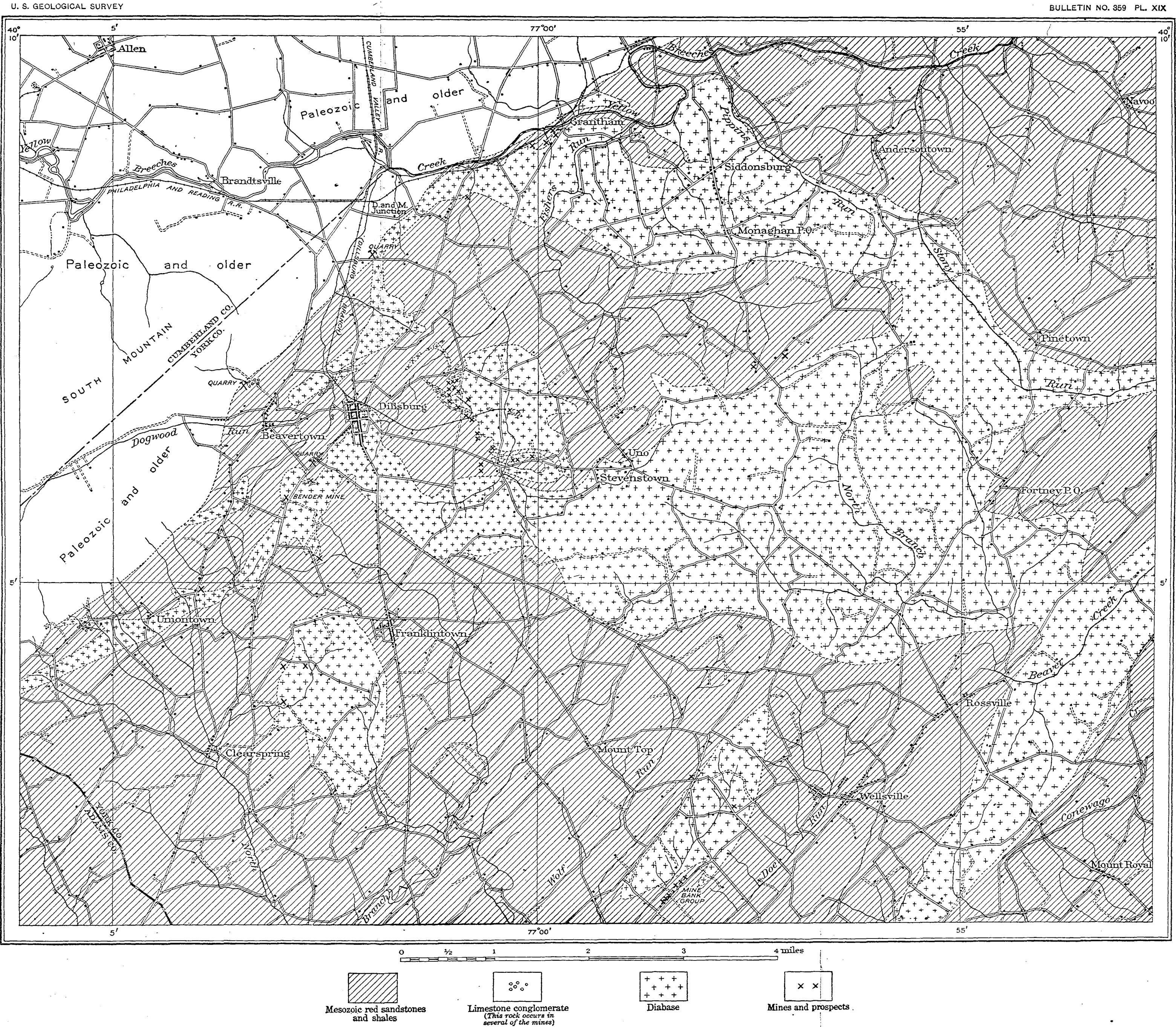

GEOLOGIC SKETCH MAP OF MESOZOIC AREA NEAR DILLSBURG, YORK COUNTY, PA. 
ore represent original bodies of limestone conglomerate which have been converted into iron ore by chemical replacement.

In the vicinity of the Dillsburg mines there are no natural exposures of limestone conglomerate and only along the Philadelphia and Reading tracks near Grantham can this rock be seen at the surface near known ore bodies. In drill holes near the old McCormick workings at Dillsburg the occurrence of limestone has been recorded.

Exposures of rock in place in this region are very few in number, but the distribution of the diabase and of the Mesozoic rocks as a whole can be recognized from the presence of residual bowlders or broken fragments in the soil. It is not possible, however, to decipher any. details concerning the make-up of the sedimentary formation. It is supposed that there may be several beds of limestone conglomerate separated fiom each other by sandstone and shales, but only the presence of the latter can be ascertained from inspection of the soil. Everywhere the materials of the surface débris show evidence of the baking which the rocks have undergone. The absence in the vicinity of the mines of fragments from the limestone conglomerate is no doubt due to the great solubility of this rock compared with the overwash of the more resistant baked sandstone fragments.

Limestone conglomerate outcrops at several places west and southwest of Dillsburg, showing that here it is an important element in the constitution of the Mesozoic formation. In the foothills of South Mountain, northwest of Beavertown, fully 50 feet of the rock is exposed in a large quarry. This quarry has beer opened around a sink hole, into which a small brook disappears. A series of sinks may be followed from this plice for nearly a mile toward the northeast. Though the sink holes suggest that the conglomerate continues as the bed rock in this direction there are no exposures, because of the heavy overwash derived from the mountain slope, and it is possible that a strip of the Paleozoic limestone sets in between the quartzites of South Mountain and the Mesozoic beds, which lie to the east. In this situation either the limestone conglomerate or the older limestone would be liable to contain underground watercourses and to give rise to the observed sinks. At a quarry on the west side of the York Springs road, about 1 mile from Dillsburg, 12 or 15 feet of conglomerate are seen lying between a stratum of red sandy shale, and massive beds of metamorphosed conglomerate may be seen a mile southwest of this quarry, at the eastern base of the diabase hill, along an abandoned railroad grade. The same rock is said to have been found in several dug wells in the northern and western parts of Dillsburg. A drilled well at the creamery penetrated 80 feet of conglomerate, and at this depth encountered an open cavity. This well overflows during wet seasons. The only exposure noted within the borough limits is just south of the mine railroad at the eastern- 
most street crossing. The occurrences which have been mentioned strongly suggest that west of Dillsburg the broad valley. occupied by Dogwood Run and its southern tributaries is underlain by limestone conglomerate. It seems probable also that beds of the same rock are present beneath the meadows east of Dillsburg, between the town and the mines. This is suspected because the conglomerate is known to occur both east and west of the flat, and because the presence of this soluble rock would be a favorable condition for the development of just such a broad basin as exists.

It may be mentioned incidentally that the presence in the soil of débris derived from the. South Mountain rocks shows that Dogwood Run formerly flowed across this depression and joined Yellow Breeches Creek by way of Fishers Run.

The geologic sketch map (PI. XIX) shows the general position of the boundary between the Mesozoic area and the older formations of South Mountain, and also the approximate distribution of the diabase intrusions in the Dillsburg region. The close association of the ore with the masses of igneous rock is well brought out by the indicated positions of the mines and prospects of the district.

\section{DILLSBURG MINES.}

\section{INTRODUCTION.}

The Dillsburg ore field has a greater extent than any of the other districts which furnish ore of the Cornwall type. Ore has been taken from more than 30 openings, including open pits and underground mines, and these workings are distributed over a zone nearly $1 \frac{1}{2}$ miles long and from one-fourth to one-half mile wide.

The annual output of the Dillsburg mines has never been large and the aggregate of the ore shipped is probably less than 1,500,000 tons, the period of production having been about sixty years. The ores have not been in general or constant demand, mainly because they are high in sulphur, but also because their iron content is low in comparison "with that of Lake ores. They compare favorably, however, with the Cornwall ore, the use of which has been on the increase for many years. Like the Cornwall ore they must be roasted before going to the blast furnace, except when they are mixed in rather small proportions with other ores. The fact that the Dillsburg ore has found even a limited market at various times during the last twenty years is sufficient ground for believing that if the mines can be shown to be capable of further output no serious difficulty need be expected in disposing of the product. The mines have been worked mainly by individual owners and lessees without sufficient capital to carry development far enough ahead of extraction to justify operation on a large scale. Could the ore fields be brought under the control of 


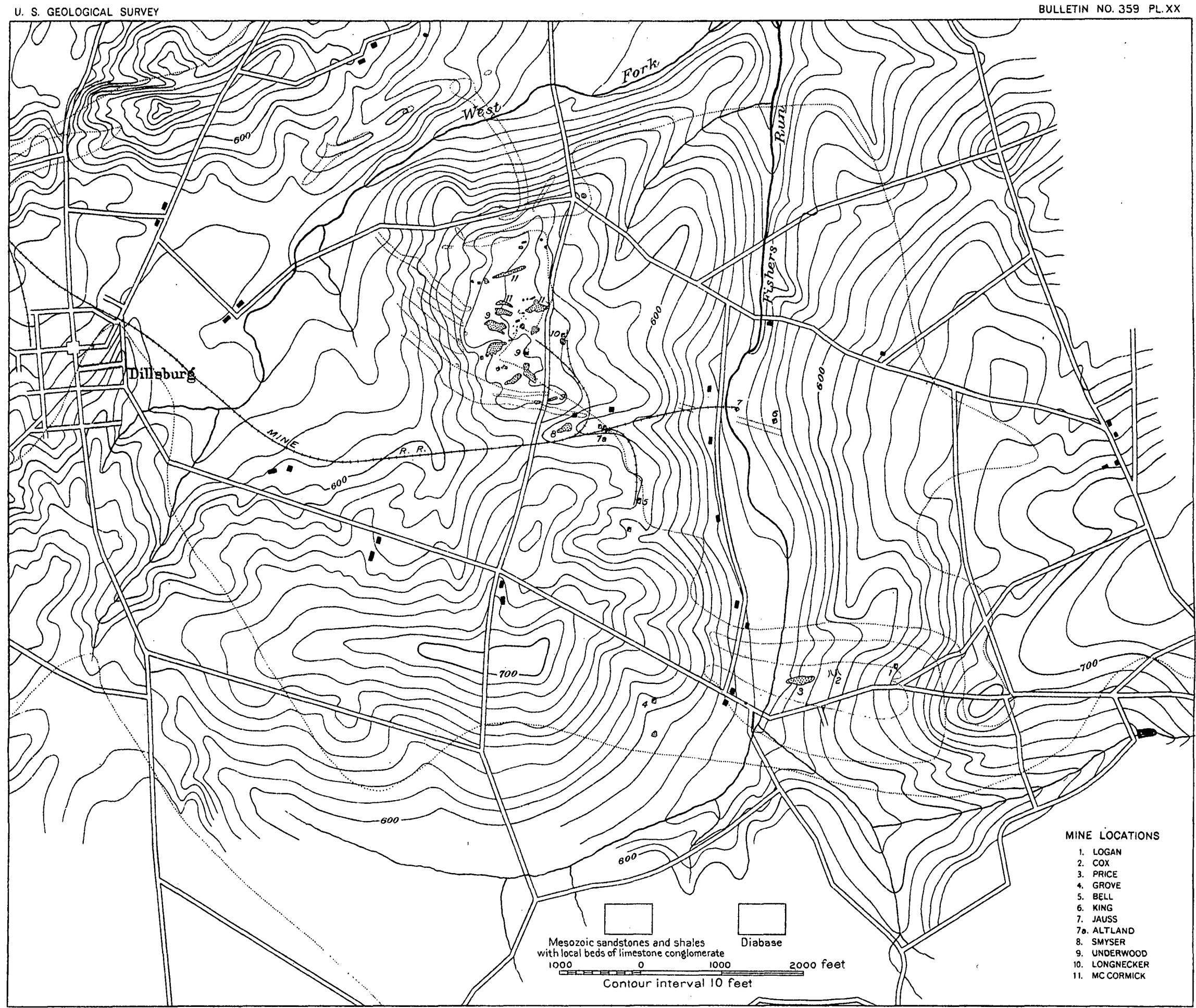

GEOLOGIC AND TOPOGRAPHIC MAP OF DILLSBURG ORE FIELDS 
interests strong enough to explore the deposits adequately and, if preliminary work should warrant, to develop them on a large scale, it seems likely that they might be brought again into successful operation. Even a moderate tonnage, if assured for a period of years, might warrant the maintenance of roasting furnaces, or, what might prove more advantageous, the installation of some concentrating process to raise the grade of the ore as it comes from the mine. Geologic considerations favor the persistence of the deposits in depth and point to the probability that ore bodies in addition to those now known might be discovered by systematic prospecting.

It is hoped that the present description and the geologic map of the district $(\mathrm{Pl} . \mathrm{XX})$ that has been prepared may aid in the future development of the deposits.

\section{DESCRIPTIONS OF MINES.}

Logan mine.-The shaft of the Logan mine, which is the most recent opening in the district, is located about 200 feet north of the wagon road leading from Dillsburg to Stevenstown. It is situated just within the outcrop of a diabase sill about 200 . feet wide, which crosses the road east of the forks. Mr. Logan, the owner of the property, was encouraged to open at this place through having observed a strong magnetic attraction determined with a dipping needle. The bottom of the diabase is evidently inclined toward the north at a low angle, for it is said to have been penetrated at a depth of 32 feet. Mr. Logan reports that 7 feet of ore was encountered just under the diabase, and that the floor is limestone conglomerate. 'The ore bed and the inclosing rocks dip toward the north. The mine was operated for a short time only, so that the extent of the ore body is not known.

North of the shaft the surface slopes gently toward a small stream fed by a spring between the two forks of the wagon road. Sandstone fragments observed along the depression occupied by this stream indicate the presence of a strip of sedimentary rock, which, as it is traced toward the east, curves to the south and crosses the right-hand road just west of the church. It is thought that this band of sandstone may run down the ravine and across Fishers Run to join a similar band which sets in from the west, but this connection can not be established from observation. North of the sedimentary strip diabase appears at the surface and continues without interruption to the vicinity of the Jauss and King mines.

South of the diabase intrusion penetrated by the Logan shaft there is a considerable strip of sedimentary rock, beyond which appears another somewhat wider diabase band. These two masses of diabase come together southeast of the mine. Still farther south there is yet another band of sedimentary rock, and beyond this is the large mass 
of diabase forming the group of hills south and east of Stevenstown. As already noted, this diabase extends westward to Dillsburg.

Inasmuch as limestone conglomerate occurs at the old Price pit, and also in the Logan mine 1,300 feet to the east, there is reason to believe that the mass of diabase which lies immediately north of both mines is a sill conforming more or less closely with the stratification of the sedimentary rock into which it has been injected. The limestone conglomerate dissolves under the action of the weather, so that its presence can not be determined by inspection of the surface débris. It is very likely that it extends along the contact with the diabase between the Logan and Cox openings, and west of the Price pit, perhaps as far as the next north-south wagon road. There is nothing to suggest how far it may extend toward the east and southeast beneath the diabase sill.

The masses of diabase occurring south of the Logan mine are probably sills, and other beds of conglomerate may be associated with them. If this is the case, it seems very likely that other ore deposits may be present in the country south of the Price, Cox, and Logan mines. Though it may be suggested that surface indications should betray the presence of any considerable deposit of ore in this part of the district, the surface débris is here apparently so thick and so liable to have moved for some distance that the weathered portions of ore beds might very well have been entirely covered. This is particularly true of the strip of sedimentary rocks which lies north of the Logan shaft. Both sides of this strip would seem to offer likely situations for the occurrence of iron-ore deposits. The Logan ore was discovered by means of the dipping needle. This instrument may prove of value in further exploration of this ground.

Cox mine.--The Cox mine is situated about 950 feet west of the Logan shaft, just south of the same diabase sill. The mine was in operation when the Dillsburg field was visited by D'Invilliers, whose report ${ }^{a}$ may be summarized as follows:

At the Cox mine, on the Price farm, the engine house is situated just north of the public road. The ore bed is mined by means of a slope about 300 feet long on a bed of magnetic ore dipping about $25^{\circ}$ a little west of north. Near by is an abandoned slope descending nearly due north for 280 feet, and in a shaft 125 feet north of the engine house the ore bed was struck near this slope at a depth of about 40 feet. The ore so far as developed seems to lie in a deposit shaped like a shell, the top and bottom of the shell coming together and pinching out the ore on all sides along the strike, as well as along the dip. The average thickness of the bed is $5 \frac{1}{2}$ to 6 feet, though in places it swells to 9 feet. Generally it has a gray dolerite trap for a hanging wall and a sandy bastard limestone for a foot wall; but

a Ann. Rept. Geol. Survey Pennsylvania for 1886, pt. 4, p. 1504. 
there seems to be no very persistent character for either. The western side of the deposit is more mixed in character than the eastern, and in places the trap wall seems to stand almost vertical, squeezing the ore into a narrow compass. The foot wall in many places appears more like white baked slate rock than like limestone, but contains some lime. In April, 188T, ore was being mined at the rate of 25 tons per day.

West of the slope a small open cut exhibits a bed of rather sandy ore, from which perhaps 200 tons have been taken.

Price mine.-A large pit situated about 250 feet west of the Cox slope is known as the Price mine. The mine is said to have been opened about 1855 and the ore is reported to have been 6 feet thick. Fragments of limestone conglomerate may be seen in a small pile of waste in the pit. The edge of the diabase sill passes just north of the pit and the dip of the rocks is evidently toward the north, as at the Iogan shaft and Cox slope. Instead of being in actual contact with the diabase the ore body appears to have been separated from the mass of igneous rock by, intervening beds of sedimentary rock. The sedimentary area between the two sills of diabase is much narrower in the vicinity of the Price mine than farther east. The southern sill comes to a blunt termination in the field northwest of and across the road from the schoolhouse.

Grove mine.-About 1,400 feet due west of the Price pit is the mouth of the Grove slope, which was opened in 1873. The dip of the rocks is given in Report CC as $24^{\circ} \mathrm{N} .10^{\circ} \mathrm{E}$. Though rock resembling weathered trap is said to occur at the mouth of the slope, the present writer was not able to find any evidence of other material than sandstone and shale in the vicinity. In the wagon road north of the opening exposures of baked shale are to be seen dipping about $20^{\circ} \mathrm{N}$.

About 400 feet south of the slope is an old excavation, doubtless an ore pit, but no information 'has been procured concerning what was found at this place or when the opening was made. The edge of the east-west diabase mass passes about 300 feet south of the pit.

Prospects near the Price farmhousc.-Mr. Logan, the present owner of the Price farm, states that a bore hole put down in the swamp east of the farmhouse encountered ore at a.depth of 75 feet. This hole appears to have been located north of the boundary of the main mass of diabase, and the ore probably lies on the under contact of the intrusive rock. Inspection of the geologic map will show the pasition of this occurrence with reference to the strip of sedimentary rock occurring north of the Logan mine. It seems that if the diabase contact follows the stratification in this vicinity ore may occur to the east as well as near the Price house, although, as stated previously, the continuity of the sedimentary strip across the creek is not proved. 
Indications of ore have been found 700 feet northwest of the farmhouse, just at the edge of the diabase, where the boundary curves toward the north. No other signs of ore are known to have been found between this point and the Bell mine.

Bell mine.-The Bell mine, which was opened in 1875 , is situated about midway between the Price pit and the Underwood group of workings. It was last worked about 1902, at which time the pillars of ore were robbed and the mine finally abandoned. From a statement by Frazer ${ }^{a}$ that bowlders of hard limestone were encountered in the upper 25 feet of the discovery shaft just north of the entrance to the working slope, it is judged that the ore lies beneath limestone conglomerate. This suggestion is corroborated by the presence of conglomerate in the mine waste, but there can be little doubt that the mass of diabase lies at no great distance above the ore body.

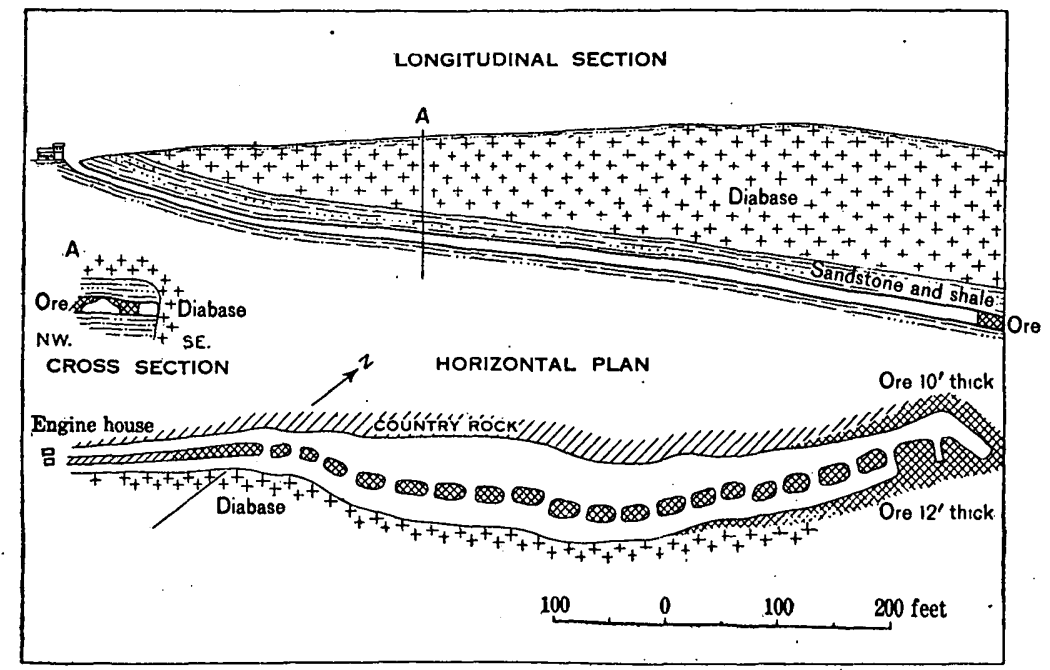

FiG. 15. - Flan arid sections of Bell mine, near Dillsburg. From Ann. Rept. Pennsylvania Geol. Survey for $\mathbf{1 8 8 5}$, p. 566 .

The mine was worked by a slope a short.distance south of the main diabase area. The course of the slope is $\mathrm{N} .10^{\circ} \mathrm{E}$. and its inclination is said to be about $20^{\circ}$, though the cross section given in fig. 15 indicates a lower angle of inclination. In 1883 the slope was about 875 feet long, but it was afterward extended 200 feet or more. The ore body is said to have had the form of a rather well-defined shoot following the dip of the inclosing strata, but limited on both sides along the strike. The maximum width is stated by $\mathrm{D}^{\prime}$ Invilliers ${ }^{b}$ to have been 60 feet, and at 875 feet from the mouth of the slope the bed was 10 to 12 feet thick. In fig. 15 the ore is shown to be cut out on the east by diabase (see Pl., XX), and from the relations shown it may

${ }^{a}$ Frazer, Persifor, jr., Second Geol. Survey Pennsylvania, Rept. CC, 1877, p. 218,

${ }^{b}$ Ann. Rept, Geol. Sưrvey Pennsylvania, pt. 4, for 1886, 1887, p. 1505, 
be that the ore body occurs adjacent to a roll in the botrom of the diabase mass where this rock locally cuts across the strata (fig. 16). The course of the diabase boundary at the surface is favorable to this suggestion.

If the suggested structure is borne out by the facts, it is not likely that other ore bodies exist toward the east, where diabase would be encountered, nor toward the west, where, though present, the orebearing stratum is probably not mineralized.

Although it is reported that the bottom of the slope is not in ore, it may be that one of the sides of the shoot has been encoun-

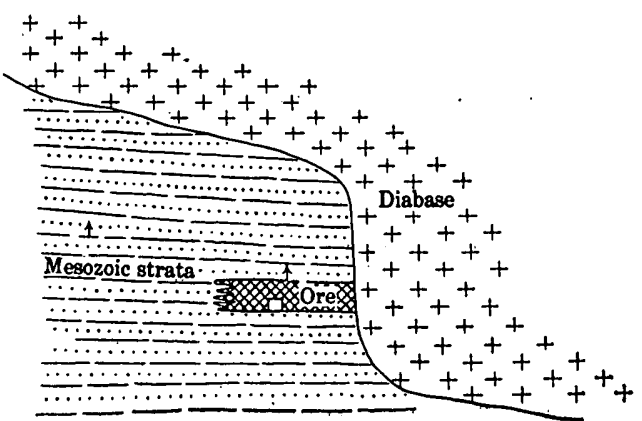

Fig. 16.-Surface plan at Bell mine, near Dillsburg, showing probable structure. tered rather than its bottom. This point may be worthy of investigation at some future time.

When the mine was abandoned the slope was 1,100 feet in length.

About 200 feet south of the Bell slope is an old slope stated by Frazer $^{a}$ to have been 180 feet long. From a point 125 feet down the

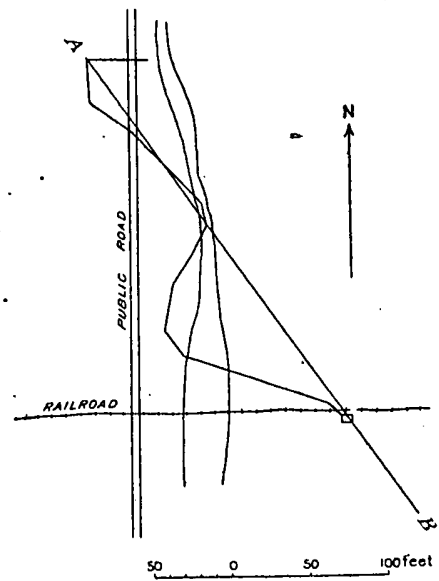

Fig. 17.-Survey of workings at Jauss mine, near Dillsburg, made in 1888. slope there is a 50 -foot drift to the east, and from the bottom another 75 feet long to the west. Exposures at the mouth of the slope show fine-grained sandstone as the hanging wall. The nearest diabase is that of the main mass, the edge of which lies about 100 feet to the northeast.

King and Jauss mines.-The King mine is situated on the east side of Fishers Run, about 3,300 feet north of the Price mine and 2,100 feet northeast of the Bell slope. The Jauss shaft (fig. 17) is situated near the east bank of the creek, 750 feet northwest of the King workings. The shafts of these two eastern mines were located by dipneedle indications. They were started in diabase, but at moderate depth both encountered ore associated with sedimentary rocks. The strata dip toward the north, so that it would appear that they must come to the surface south of the shafts. Nevertheless, the presence of these sediments would not be suspected from examination of the sur-

a Frazer, Persifor, jr., Second Geol. Survey Pennsylvania, Rept. CC, 1877, p. 218. 
face, because their outcrop is obscured by an overwash of diabase soil. Just north of the railroad track, however, on the west side of the creek and about 800 feet from the Jauss shaft, a patch of sediments may be inferred from the occurrence of sandstone fragments in the soil. It seems probable that these two masses of sedimentary rock may be connected, but the surface is covered to such an extent that nothing positive can be made out. It is entirely possible also that the sediments of the western patch may extend farther west than is indicated on the map ( $\mathrm{Pl}$. XX), for in this direction there is a broad swale in which the presence of diabase soil may be misleading as to the actual extent of the intrusive rock. The trend of the two sedimentary strips is in the direction of the Longnecker shaft on the west and toward an embayment in the outer boundary of the diabase area on the east. Along this general line the main mass of diabase is seen to be partly divided by intercalated sandstones and shales. Whether this separation becomes more or less extensive in depth can not be judged, but from the fact that in the Longnecker workings the bedded rocks ap-

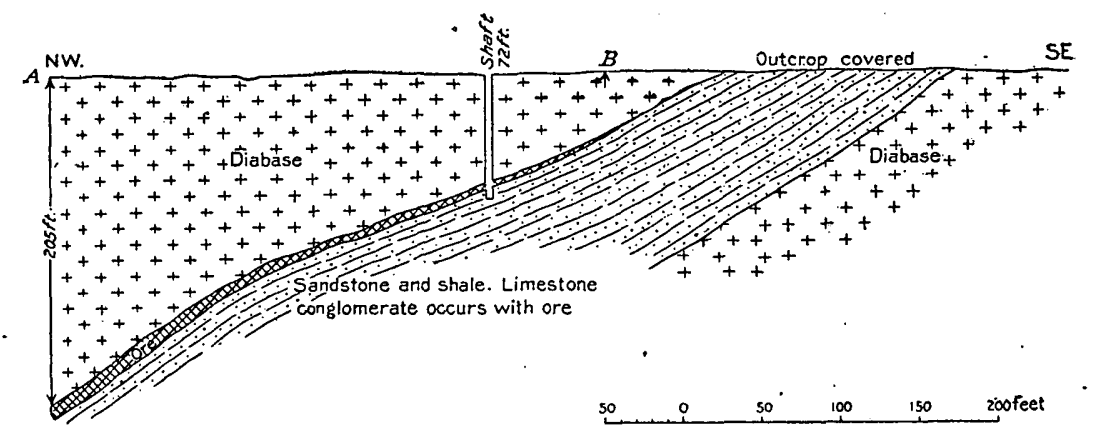

FIG. 18. -General structure section at Jauss mine, near Dillsburg (along line $A-B$, fig. 17).

pear to rise to a crest beneath the diabase, it seems possible that the dividing masses may extend farther along the strike underground than is apparent from surface indications, and that they may even connect with one another.

It might be worth while to explore the western patch of sedimentary rocks mentioned above. If this is ever done it may be assumed that the northern contact with the diabase dips toward the north, as at the Jauss mine. On this basis the best scheme for proving the ground would be to sink shafts or bore holes just within the diabase area in order to catch the contact on the dip. The lower contact of the bedded rocks might also be explored both in this vicinity and south of the Jauss mine. A cross section showing the supposed structural relations in the vicinity of the Jauss mine is given in fig. 18. It is supposed that a section through the western sedimentary patch would be very similar, 
The following notes concerning the King mine are abstracted from Frazer: ${ }^{a}$

The shaft, which was sunk in 1876, passes through 23 feet of soil and diabase, beneath which there was 9 feet of ore. Toward the east a drift 20 feet long encountered an oblique wall of diabase on the south side. Between this wall and indurated sandstones on the north the ore formed a wedge-shaped mass. From the end of this 20-foot drift a slope was opened upward until clay was encountered. The course of this slope $\left(\mathrm{N} .3^{\circ} \mathrm{E}\right.$.) and its angle of inclination $\left(22^{\circ}\right)$ give the apparent direction and amount of the dip of the ore bed. From the bottom of the slope a drift was run N. $5^{\circ} \mathrm{E}$. for a distance of 50 feet, following a fault showing slickensides. Along this gangway the fault rock is a broken-up mixture of sandstone and trap rock. About 20 feet east of the slope indurated sandstone exhibits a dip of $23^{\circ}$ in a direction $\mathrm{N} .40^{\circ} \mathrm{W}$, but the dip of the vein is reported to be N. $10^{\circ} \mathrm{W}$.

The Jauss shaft is situated just west of Fishers Run, at the eastern terminus of the branch railroad. The shaft was sunk at a point where the dip needle showed a marked magnetic attraction. About 72 feet of diabase was penetrated before the 7 -foot ore bed was encountered. The floor of the mine is limestone.conglomerate. As depth was gained the ore bed was found to thicken along the dip, and in the lowest workings, 205 feet below the surface, a large body of ore is reported. Stoping was carried about 30 feet above the point where the ore was cut through by the shaft. A survey made in 1888 shows the mine workings as extending 270 feet northwest of the shaft. In this distance the ore bed falls 133 feet, giving an average inclination. of nearly 50 feet per 100 , or about $30^{\circ}$. The dip appears to be somewhat steeper in the lower than in the upper workings.

Material on the waste pile shows that some of the ore at least has been formed by replacement of limestone conglomerate, though most of the material intimately associated with the ore is a light-green rock which appears to be an altered shale. Although no fragments of any rock except diabase are to be seen in the field south of the shaft, there can be little doubt that the sedimentary rocks which accompany the ore would be found beneath a relatively shallow cover of soil. On the geologic map (Pl. XX) a strip of sediments is indicated as extending southeast to the King mine.

Altzand mine.-Just where the switch of the Bell mine joins the main track there are three shafts, two north and one south of the railroad. These constitute the Altland mine, concerning which the notes in the following paragraph are condensed from the description by D'Invilliers: ${ }^{b}$

a Frazer, Persifor, jr., op. cit., p. 212.

' Ann. Rept. Geol. Survey Pennsylvania for 1886, pt. 4, 1887, pp. 1506-1507.

54370-Bull. 359-0S-6 
This mine lies northwest of the Bell-mine and is opened by a shaft 62 feet deep, from the bottom of which a slope extends northward on the ore bed. This bed evidently lies geologically higher than the one worked at Bell's. Its outcrop was formerly worked a short distance south of the shaft. The shaft encountered ore at 57 feet and the slope is driven northward on a $23^{\circ}$ dip for about 125 feet, the ore bed ranging from 4 to 7 feet in thickness. All along the slope the hanging wall seems to be a fine-grained trap, in places carrying small crystals of iron pyrites and here and there nodules of lime. But in the drifts at the bottom of the slope for 25 feet on each side an indurated slate rock wedges in between the trap and the ore, forming the hanging wall. The ore body seems to have a lenticular shape, as at the Cox mine, being thickest at the slope and thinning rapidly both east and west. The upper workings are confined to the vicinity of the slope, but at the bottom the ore bed has a workable thickness for a greater distance along the strike. The ore is rather micaceous.

From the surface distribution of the diabase, so far as it can be made out, the Altland ore seems to lie some distance below the bottom of the main diabase mass. It is possible that the trap mentioned by D'Invilliers is a thin eastward extension of the sill shown on the geologic map ( $\mathrm{Pl} . \mathbf{X X})$ as ending west of the Longnecker tract. If this is the case, the Altland bed and the ore formerly worked at the Smyser pit probably correspond in stratigraphic position, and other ore shoots may exist beneath. Also, if the Smyser and Altland beds occupy the same stratigraphic horizon, the strike of the strata is diagonal to the contact of the main diabase, which is therefore slightly crosscutting in this vicinity, just as it is farther northwest, near the Underwood workings. From this conclusion it would seem worth while to seek for ore along the strike of the ore bed east of the Altland mine. At the contact with the diabase the structural conditions would be like those which have been deduced for the Bell deposit.

Smyser mine.-The Smyser open pit is situated about 450 feet west of the Altland workings, and, as already stated, the ore bed probably corresponds in position with that in the Altland mine. 'The Smyser deposit was opened in 1852, and 3,000 tons of ore are reported to have been won from it. Although the ore is said to have rested upon a saddle of diabase, the nearest diabase which can be determined from surface observations is the sill which passes north of the pit. This sill appears to end a short distance west of the Jongnecker switch, though it is possible that it may extend somewhat farther east.

A small body of ore said to have been uncovered in the railroad cut just west of the road crossing, about 500 feet distant from the 
Smyser pit, was never opened. It apparently lies in lower strata than those at the Smyser pit.

Bowlders of ore may be found in the cultivated field about 400 feet north-northeast of the Smyser pit and 200 feet north of the dwelling house. This locality is apparently inside the diabase area, but it seems possible that an irregularity in the bottom of the diabase mass has brought a small patch of sediments to the surface. If this supposition is correct, the occurrence of ore at this place is favorable to the view that ore deposits will be found in many places beneaich the diabase when extensive explorations are undertaken.

Underwood workings.-The most productive ground of the Dillsburg field has been the northeasterly 35 acres of the Underwood property and the near-by portions of the McCormick tract on the north and the Logan tract on the east. On the Underwood tract there are five large open pits and several smaller excavations, all of which were exhausted previous to 1874 , and four deep mines, which have been abandoned since 1887 .

The southernmost of the Underwood workings are two pits situated about 500 feet northwest of the Smyser pit, on opposite sides of the north-south wagon road. These two openings are doubtless on the same ore body, which they have developed for about 400 feet along its course. Though the depth of the workings is not known, the ore must have been followed for some distance on a northerly dip, because there are depressions about 175 feet north of the western opening which appear to be the result of the caving in of underground workings. The narrow diabase sill which passes north of the Smyser pit touches the south side of the western opening, and just north of - the pits is another sill which strikes northeast and west. The second sill can not be traced east of the wagon road, though it may extend for some distance in this direction. The two sills approach each other toward the west and finally unite. The main diabase contact, running from southeast to northwest, passes near the northeast corner of the eastern pit and the strike of the ore bed is evidently diagonal to this contact and also to the course of the southern sill, but it is nearly parallel with the trend of the northern sill.

The next openings, to the northwest, are two large pits in which the general line of excavation runs from the outlying sill on the southwest diagonally across to the main contact on the northeast. The boundary of the main diabase area crosses the northeastern of the two pits, which is said to have been the first mine opened in the Dillsburg field. These pits must have furnished a very large amount of ore. In 1873 a shaft was sunk in the bottom of the eastern pit (Derrick shaft), and is said to have passed through 25 feet of diabase and 28 feet of ore. The ore body is known to have been worked for a distance of 250 feet northeast of the shaft and it probably connects 
with the ore worked in the three deep mines lying immediately to the north. Between the open pits and the Underwood slope the ore bed apparently lies very flat. Limestone was encountered in the workings from the Derrick shaft.

About 600 feet northwest of these pits there is another large pit, the longer axis of which trends northeastward, nearly parallel with the diabase contact, which lies about 50 feet to the southeast. Waste, apparently derived from these workings, contains limestone and masses of garnet rock. A shaft was sunk about 50 feet beyond the southwest end of the pit, but whether or not ore was mined from this opening is not known.

Farther north there are two large pits between the one just described and the McCormick property line. In both of these the strike of the ore bed is slightly south of east. Nothing can be seen of the rocks which inclose the ore and it is not known to what depth the deposit was excavated.

Between the three western pits of the Underwood group and the edge of the diabase mass many small ore pockets were mined out at the surface, but the only important excavation in this part of the tract lies in the angle of the diabase boundary, about 300 feet south of the big McCormick pit. In the northeast corner of this excavation thin-bedded layers of baked sandstone may be seen dipping N. $80^{\circ}$ E. at an angle of about $20^{\circ}$. 'The ore evidently passes under this sandstone, which therefore lies between the ore and the diabase seen on the east side of the pit.

Of the three deep mines on the Underwood tract which remain to be described, the oldest was opened by the so-called Underwood slope, the position of which is shown on the maps (Pl.XX and fig. 19). The following notes on this mine are condensed from Frazer's report: ${ }^{a}$

The slope sinks due north at an angle of $28^{\circ}$. Ore was not followed from the surface, but was reached at a depth of 26 feet. Diabase is exposed at the mouth of the slope, and the ore, where first encountered, is said to have been 18 feet thick. The dip of the ore beds is steeper in the lower workings than in the upper part of the mine. The foot wall is sandstone intermixed with limestone; the hanging wall is diabase. The distance between the walls varies from 6 to 30 feet. Three levels have been opened. On the first level, at 120 feet, drifts extend 100 feet east and west of the slope. The second level, at 180 feet, was opened 90 feet east and west, and the third level, at 200 feet, was opened 110 feet east and 120 feet west. The ore body was developed by raises about 20 feet apart, extending from level to level. 
Apparently referring to this same slope, D'Invilliers states in his 1886 report $^{a}$ that the workings were carried down 500 feet but were abandoned. He also says that the slope was carried down with the true hanging wall (that is, diabase) on top; but within a comparatively short distance the bed forked into an upper and a lower seam, with a wedge of slaty sandstone between. The gangways driven east ${ }^{b}$ from the slope showed the ore being rapidly cut out by the convergence of the walls, and the drifts were continually kept turning toward the northeast in order to keep within the ore body. The best ore is said to have occurred near the place where the bed

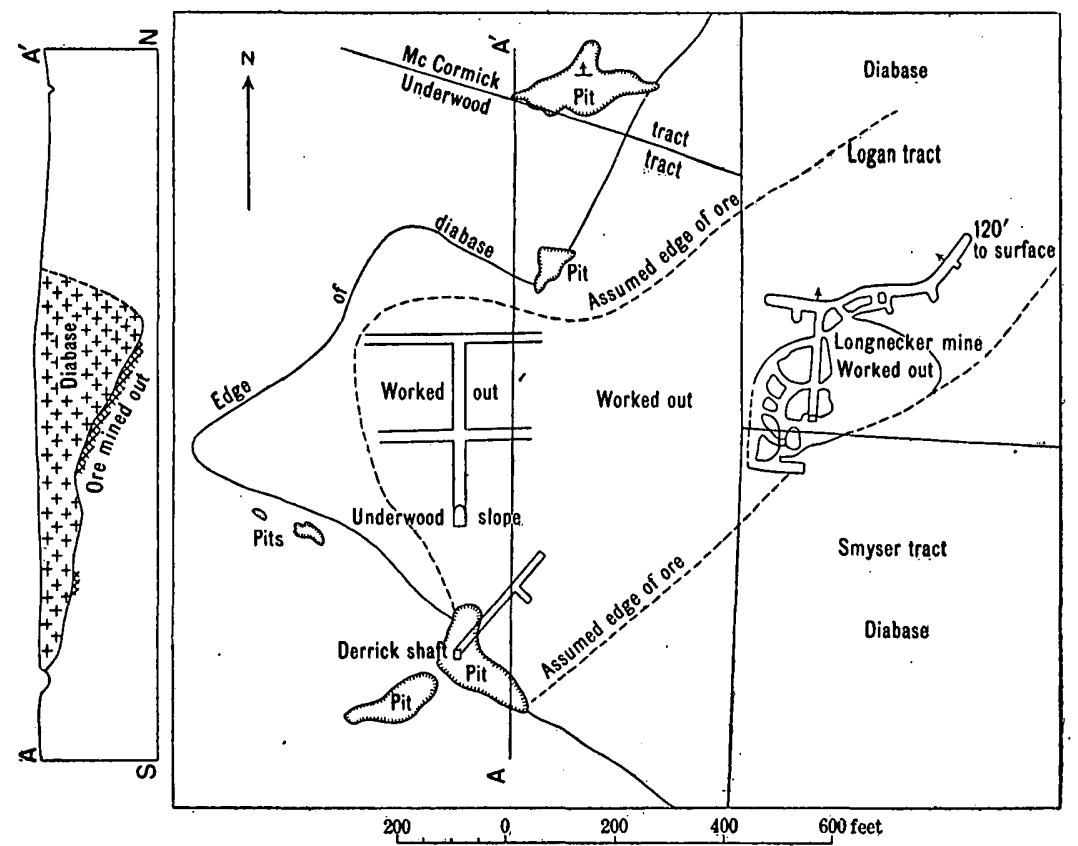

Fia. 19.-Plan and section of Underwood and Longnecker mines, Dillsburg, showing probable trend of ore bed.

pinched; and where the bed is thickest the ore is mixed with slaty limestone layers and carries iron pyrites.

In April, 1887, the mine was worked by a shaft 96 feet deep which is said to have passed through three ore beds-the first at 38 feet, 7 to 8 feet thick and rather lean; then 14 feet of sandstone; 8 feet of good ore; 26 feet of sandstone; and the bottom ore bed, 15 to 20 feet thick. These extensive workings lie entirely east of the old slope. As in the other mines, the foot wall is a hard white calcareous sandstone, and the hanging wall is diabase; but between the

a Ann. Rept. Geol. Survey Pennsylvania for 1886, pt. 4, 1887, p. 1508.

"This word is west in the original, but the concurrence of the words "west" and "northwest" in this sentence makes it unintelligible as it stands. 
walls lenticular masses of sandstone and slate wedge into the ore body. It is no doubt due to the swelling of such wedges that the three beds of ore were found in the shaft. The middle bed, which has been somewhat largely developed, is said to lie between beds of altered sand rock. In the lowest bed immense chambers have been opened where the ore swells locally; but where the bed is 15 to 20 feet thick it contains seams of limestone and bowlders of barren rock. The two upper beds are regarded as splits from the lowest or main bed. The mine may have furnished from 20,000 to 25,000 tons of ore, a veraging 40 per cent of iron.

The last mine opened on the Underwood tract is described by D'Invilliers " under the heading "Longnecker mine," a name now applied to the mine on the Logan tract. The writer was not able to determine the location of this opening, which is said to lie a little east of the Underwood mine.

According to D'Invilliers, the shaft is 95 feet deep and the slope extending from its bottom has reached the McCormick line and is probably from 400 to 450 feet long. On the east four gangways have been driven toward the Longnecker mine, and from the bottom of the slope a gangway has been driven 150 feet west toward the Underwood mine. About 50 feet from the slope, in a stope above the west gangway, the ore in places is 20 to 30 feet thick. No new features are presented in this mine, and it may be considered that the ore is an extension 400 feet farther to the east of the Underwood bed. It may be, however, that there are two ore lenses which overlap each other.

The apparent relations of the ore and the diabase, so far as they may be judged from the recorded descriptions of the Underwood slope, are illustrated in the cross section (fig. 19).

The position of the section is 90 feet east of the Underwood slope and its direction. is north and south.

Longnecker mine.-The mine now known as the Longnecker was formerly called the Logan mine. It was opened by the owner of the property, J. N. Logan, in 1874 . The shaft was located from dip-needle indications, but 27 feet of diabase was penetrated before the ore was cut. Diabase soil and bowlders cover the surface near the mine, and it is evident that the ore must lie beneath the mass of this rock. Material on the mine dump shows that limestone conglomerate is present in the workings.

The ore bed is said to have been 20 feet thick at the shaft and to have averaged 10 feet in the mine. From the bottom of the vertical shaft, 51 feet deep, a slope toward the north starts at an inclination of $28^{\circ}$, but flattens somewhat as depth is attained. Mr. Logan 
states that the workings extend about 300 feet north of this shaft and that the east drift of the lowest level is 190 feet long. The extent of the workings in 1885 is shown by the plan (fig. 20). Considerable work has been done since this survey was made. The vertical section which accompanies the plan does not correspond with the relations as they are stated above, but it is reproduced as

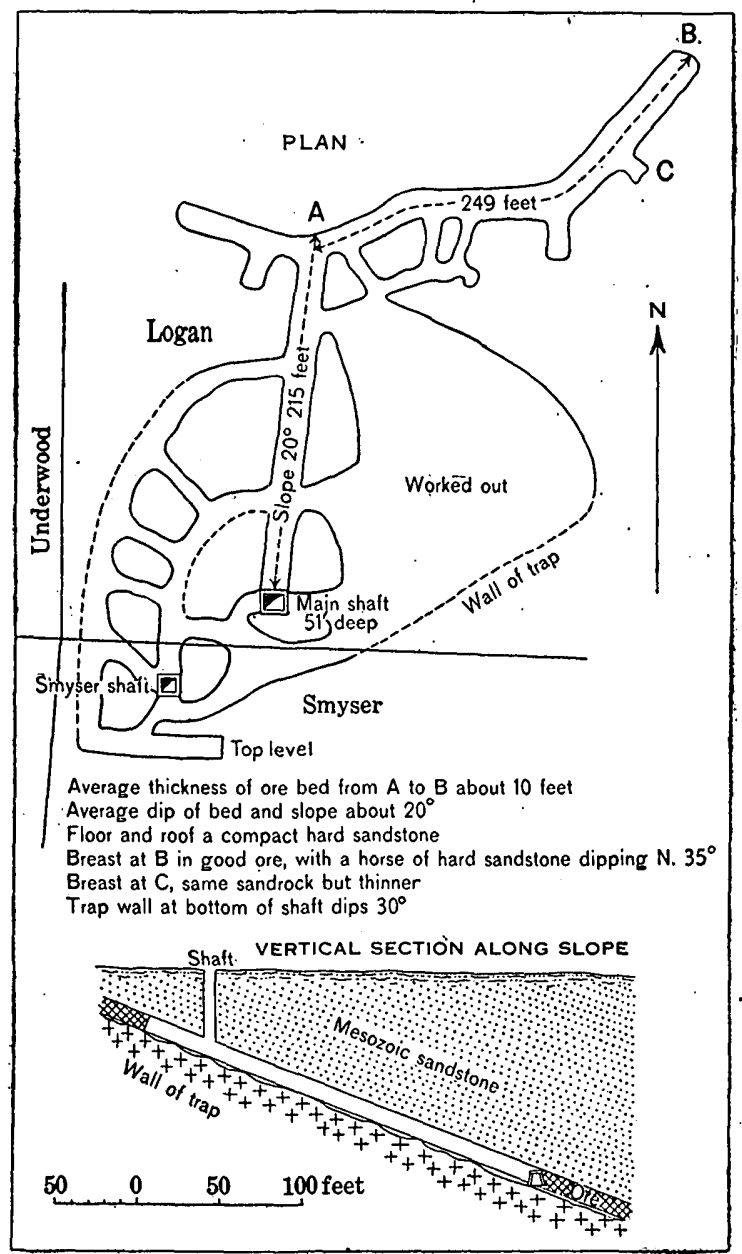

FIg. 20.-Plan and cross section of Longnecker mine, on Logan tract, Dillsburg. From Ann. Rept. Second Geol. Survey Pennsylvania for 1855 , p. 568 .

originally drawn. From the inclination of the slope the ore bed should outcrop about 50 feet south of the shaft, but at this place the surface rock is undoubtedly diabase. The map shows that the underground workings reach a point fully 100 feet south of the shaft, so that the under side of the diabase must lie nearly flat south and southwest of the shaft, as it does in the ground south and southeast of the Underwood slope. In the vicinity of the shaft the bottom 
of the diabase takes an abrupt dip toward the north, as in the Underwood mine, so that both the Longnecker shaft and the Underwood slope appear to have penetrated the ore bed just at the angle where the steeper dip begins.

The very considerable extent of the ore bed shown by the Underwood and Longnecker workings furnishes a strong reason for believing that the Logan tract offers good ground for further development. The Underwood tract seems to have been completely worked out, though from the statement that the Longnecker workings extended north to the McCormick line it seems possible that the same bed of ore continues into the McCormick tract. A consideration of all the deep mines of this vicinity, however, suggests that the actual trend of the ore is toward the northeast, so that future discoveries are more likely to be made in the Logan tract than elsewhere. The boring which was made in the McCormick pit appears to be not deep enough to reach the extension of the Underwood ore. It is reported that a boring was made about 1,500 feet north of the Longnecker shaft, but no record of this work is available.

McCormick mines.-On the McCormick tract, situated north of the Underwood tract, there are three large pits and several small openings, all of which were abandoned before 1875. No large masses of diabase are present near most of the excavations, but the largest pit is situated at the western edge of the main diabase, about 200 feet north of the pit in the angle of the diabase boundary on the Underwood tract. This large pit is said to have been opened about 1850 , and it is apparent from the fact that its area is nearly 12,000 square feet that it must have furnished a large amount of ore. The size of the vein is not recorded, but the longer axis of the excavation trends somewhat north of east, showing that the strike of the ore bed is in that direction. The position of the slope by which the mine was worked indicates that the strata have the usual dip toward the north.

Frazer states ${ }^{a}$ that a shaft was sunk from the bottom of the pit to a depth of 140 feet, and that about 100 feet north of the pit a 20 -foot slope was put down 60 feet on the vein of ore, which was 4 feet thick at the bottom. He gives the following record of a drill hole in the large pit: ${ }^{b}$

Record of bore hole No. 5, sunk in McCormick \& Co.'s old bank.

\begin{tabular}{|c|c|}
\hline Soil & $\begin{array}{l}\text { Feet } \\
\text { 8. } 84\end{array}$ \\
\hline Green sandstone & .17 \\
\hline on ore & .17 \\
\hline Gray sandstone-- & 4.50 \\
\hline White sandstone & 6.17 \\
\hline eddish-green sandstone-_ & 12.08 \\
\hline
\end{tabular}


Black (?) trap

Feet.

Gray sandstone.

23.07

Iron ore

3.25

White sandstone_-_-_._.

Iron ore

White sandstone

Limestone and flint.-_._-_._.

Limestone and fire clay-_._._._-

Red sandstone-_._.

Green sandstone_-_._._.

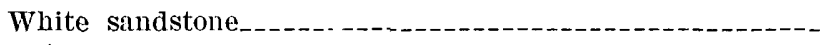

Green sandstone

Iron ore-1-_--_-

Sandstone

Sandstone and ore.-_-

Limestone and flint_._...

Ore and sandstone._. 50

Green sandstone_._. 500

White sandstone____ 500

Green sandstone__. 600

White sandstone._._. 1.00

Gray trap____ 200

White sandstone____.___. 200

Limestone__. 300

Gray sandstone

Red sandstone._.

White sandstone 4.00

Red saudstone

White sandstone____. 400

Red sandstone._. 300

White saudstone_-_- 50

187. 83

It is evident from the above record that the mass of diabase which outcrops east of the pit does not dip beneath this ore body. The contact of the diabase with the stratified rocks might be supposed to be highly inclined and strongly crosscutting, except for the fact that about 400 feet toward the southeast, at the bottom of the Longneckerslope, the lower surface of the diabase is not more than 200 feet deep. It seems probable, therefore, that this lower surface dips rather gently toward the east or northeast. The most likely situation for a continuation of the ore body would be where the north ward-dipping strata meet the eastward or northeastward dipping bottom of the diabase.

Though the drill-hole record shows thin layers of ore at five horizons and limestone at three horizons, it is not likely that strata equivalent to those containing the ore in the Underwood deep mines have been reached. If these beds continue with the same dip that they have in the Underwood slope, their position would be about 450 feet from the surface beneath the McCormick pit. 
The second McCormick pit is a long, narrow excavation situated just north of the property line, about 200 feet farther west. (See fig. 21.) Nothing is known of this ore layer beyond the fact that it strikes slightly north of west. The pit is about 50 feet north of the nearest Underwood pit.

.The McCormick long cut lies about 300 feet northwest of the large pit and 230 feet north of the excavation last mentioned. Though there are some small openings beyond, the long cut is the northernmost of the formerly productive mines of the Dillsburg field. The ore bed was opened for a distance of 325 feet along the strike and

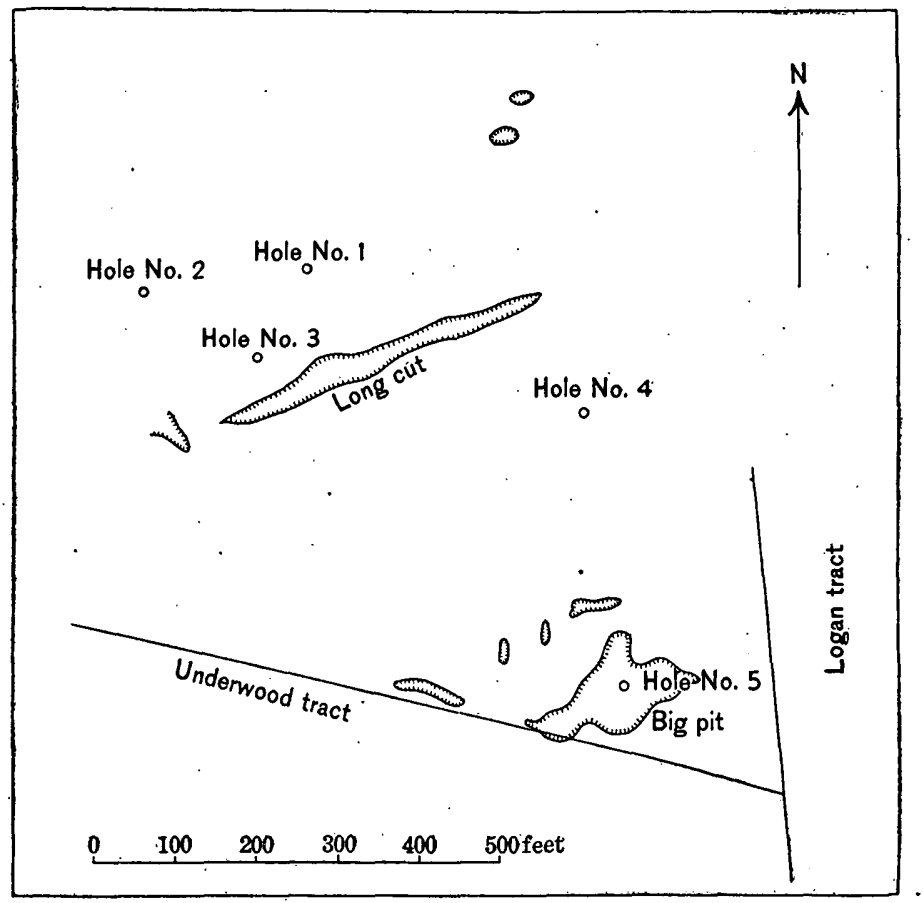

FIG. 21.-Sketch map showing situation of pits and test holes on McCormick tract, Dillsburg.

small openings were made at several places west of the main cut. The following notes are taken substantially from Frazer: ${ }^{a}$

A dolerite, which occurs in this mine at the surface and appears to constitute the top rock of the ore, dips N. $5^{\circ} \mathrm{W}$. from $27^{\circ}$ to $34^{\circ}$. Two slopes were driven to find the ore. The upper one followed the vein in between well-defined walls at a normal angle to the inclination of the sandstone layers. The upper sandstone was continued in the deep, but the foot wall was cut out by a dike of diabase. The lower slope, of about $30^{\circ}$ to $45^{\circ}$, was continued for 180 feet and passed through the ore, which appeared to be a very irregular deposit. In 1875 it was nearly exhausted. 
Near the west end of the cut, fine-grained baked sandstone may be seen to form the hanging wall, but no evidence was found on the surface that diabase is present near the mine. The sketch map (fig. 21) shows the position of the several bore holes, the records of which, here given, are taken from Frazer: ${ }^{a}$

Record of bore hole No. 1, north of McCormick long cut.

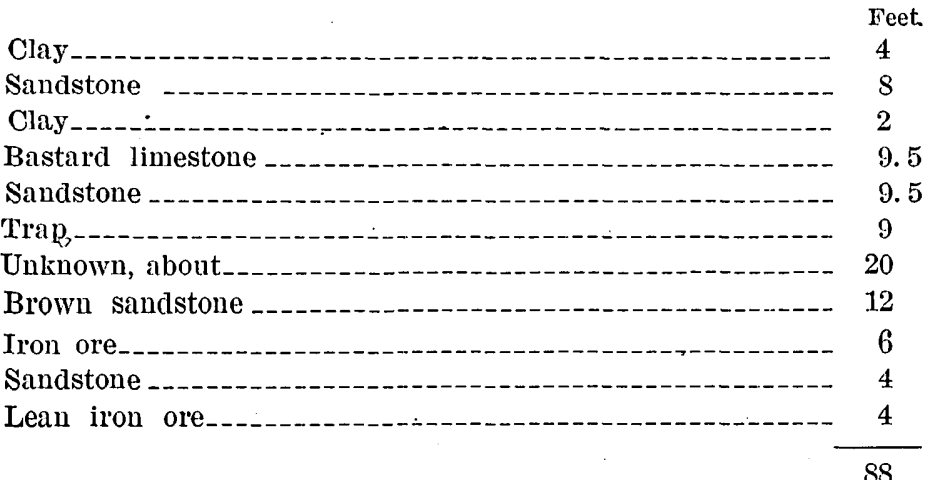

Record of bore hole No. 3 , north of MICCormick long cut.

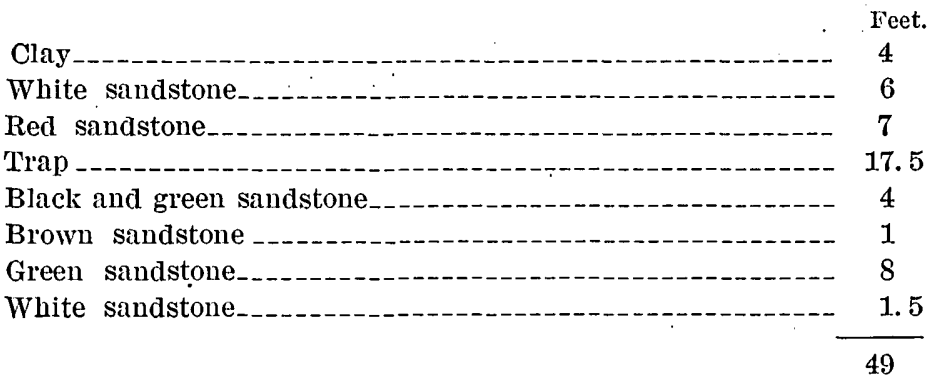

Record of bore hole No. 4, southeast of McCormick long cut.

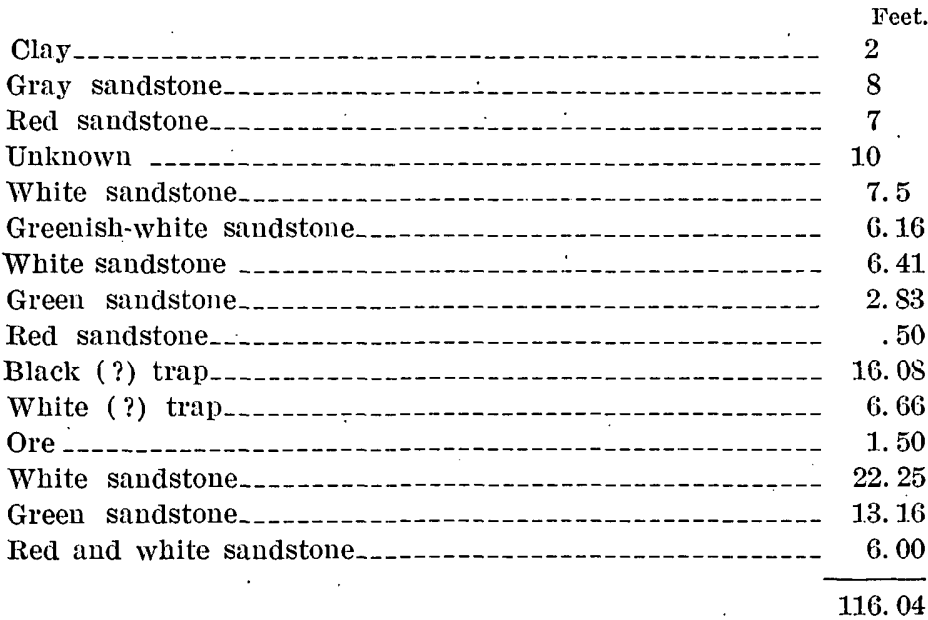


Hole No. 1, located about 110 feet north of the long cut, evidently penetrated the ore bed, which was mined from the surface. The record of hole No. 2 is not given. To judge from the known dip of the strata, hole No. 3, about 50 feet north of the cut, must also have passed through the horizon where the ore body should be, though no ore was reported. The $9 \frac{1}{2}$-foot bed of limestone encountered in hole No. 1 probably outcrops north of hole No. 3. The record of hole No. 5 is given on pages $88-89$.

The position of two small pockets of ore about 200 feet north of the east end of the long cut is indicated on the map (Pl. XX). A small quantity of ore is said to have been mined from a shaft 1,200 feet northeast of the long cut in the northeast angle of the crossroads.

The position of this shaft is very near the boundary of the main mass of diabase.

Mr. Logan states that thin seams of magnetite, or of specular hematite, have been found at several points in the fields of his home farm, about half a mile northwest of the McCormick long cut. In this vicinity there are several minor bodies of diabase, but the shales and sandstones are not generally baked, as they are in the neighborhood of the old mines.

\section{DIABASE INTRUSIONS WEST OF THE MINES.}

The present examination of the geologic features of the Dillsburg field has revealed the presence of several bodies of diabase on the western slope of the hill on which most of the old mines are situated. The intrusions, which are four in number, appear at the surface as narrow bands, and though the relation which they bear to the inclosing rocks can not be observed, they are probably sills, more or less closely conforming with the bedding of the rocks which incase them. One of the bands is the westward and northwestward extension of the two narrow strips of diabase which cross the wagon road just south of the Underwood pits and come together about 500 feet west of the road. Where the two forks merge the band is 250 feet wide, though it becomes narrower toward the west. Its observed length is about 2,500 feet, but its western termination is not seen because of the deep soil in the meadows between the ore fields and Dillsburg. The three northern bands extend eastward nearly to the brow of the hill. The middle band runs northwestward for 800 or 900 feet, to a point where it appears to terminate, though this is not certain, for the surface débris in this vicinity is greatly mixed. The other bands may be traced toward the northwest until they are lost under the meadow soil. The northernmost band may be followed nearly to the wagon road, as shown on the map ( $\mathrm{Pl}$. XX).

On page 94 reasons are given in support of the suggestion that beds of limestone conglomerate which occur in the vicinity of Dillsburg 
may extend eastward and underlie the meadows between the town and mines. If any such continuity of conglomerate layers actually exists, they must traverse the ground occupied by the four diabase sills. From what has been learned concerning the geology of the Dillsburg deposits, it seems that the possibility of beds of limestone conglomerate being locally in contact with these intrusions makes all of this ground worthy of careful exploration. The absence of ore indications in the soil can not be considered conclusive evidence against the existence of ore bodies, as the ore is known to break down completely under long-continued action of the weather, and as on the hill slope the earthy material resulting from the superficial disintegration of an ore body would be hidden more completely than on nearly level ground because of the gradual downhill movement of the rock fragments and soil.

\section{PRACTICAL CONCLUSIONS.}

A practical question to which an unqualified answer can not be given is whether or not deposits of magnetic iron ore may yet be found in new localities in the Dillsburg district. It seems unlikely that new ore bodies will be discovered from surface showings encountered in tilling the soil, as in the earlier days of the district. Four of the ore bodies have been discovered by means of the magnetic dipping needle, and others may yet be found in the same way. In this connection, though no magnetic observations were made during the present investigation, it may be pointed out that in using the magnetic needle difficulties may arise from the attraction due to masses of diabase, for it is well known that this rock possesses magnetic properties in certain places. On the other hand, it seems possible that there may be ore bodies which the needle will not detect.

Whatever may be the truth on the foregoing points, their consideration is secondary to the understanding of the geologic features of the district, the presentation of which is the object of this report. From a purely geologic standpoint, deposits of ore like those which have already been worked might be expected to occur west of the ore fields along the borders of the several diabase intrusions near Dillsburg. The particular feature which distinguishes this part of the district and makes it seem more likely that ore deposits may be present here than at other places in York County where large masses of diabase occur is the existence of beds of limestone conglomerate. This rock is so closely associated with the ore bodies of the mines already worked that its presence must be regarded as one of the favorable conditions for ore occurrence, and where it comes into contact with diabase the chances for finding ore seem worthy of attention.

The mile-wide band of diabase which runs east and west just south of the ore fields narrows somewhat and assumes a northwest- 
erly trend about 1 mile southeast of Dillsburg. The southern part of the town is underlain by the mass of intrusive rock, but here the band makes another turn, this time sharply toward the southwest, and it continues in this general direction for about 8 miles to its termination a mile or more northwest of York Springs. Southwest of Dillsburg minor indications of ore have been found at several points along the borders of this intrusion, and at two places small bodies of ore have been mined, as already noted. It is not possible to show the presence of limestone conglomerate at any of these places, though outcrops at several points show that beds of the rock are present beneath the low meadows between Dillsburg and Beavertown. There can be little doubt that the limestone conglomerate and diabase actually come together in several places, though the contact may lie some distance beneath the surface.

On the geologic map (Pl. XIX) the position of known outcrops of limestone conglomerate has been shown. At the quarry beside the Dillsburg-York Springs road, 1 mile southwest of Dillsburg, a heavy bed of the conglomerate dips toward the southeast, so that if the diabase, which lies east of the road, is a crosscutting mass, as seems likely, the stratum should come into contact with the igneous rock in this direction. Though baking of the sediments does not extend as far as the quarry, the presence of ore at the surface one-fourth mile to the south shows that solutions capable of depositing iron were active, and the chances that the conglomerate bed is mineralized at the contact seem worthy of consideration.

One mile southwest of the quarry mentioned in the foregoing paragraph; limestone conglomerate has been exposed at the eastern base of the diabase hill along an abandoned railroad grade. Here a considerable degree of metamorphism is shown by the presence of silicate minerals in the conglomerate, but no iron minerals have been introduced. The absence of ore in this place is possibly to be charged to the small size of the diabase intrusion lying immediately west.

It is impossible to discover the attitude of the strata between the outlying body of diabase just mentioned and the long dike which extends southwest of Dillsburg, but the rocks are much baked as the edge of the dike is approached, and beds of limestone conglomerate are likely to exist beneath the surface débris. In the event of a successful outcome of future explorations in other localities, it may yet be thought desirable to determine whether or not limestone conglomerate occurs in the vicinity of this southwest dike, and if it is found, to explore those places where it is likely to come into contact with the diabase. The existence of ore at the Bender mine and of ore indications about half a mile southeast of that opening shows at least that mineralizing waters were active in the neighborhood. 
The dike or sill of diabase which crosses Dogwood Run northwest of Dillsburg has been traced in a northwesterly direction and found to connect with the wide intrusion south of the Grantham mines. Exposures of limestone very near the diabase are seen in the wagon road near the gristmill, in a railroad cutting near the upper end of the mill pond, and along the creek above the pond.

The attitude of the main diabase mass can not be made out, but in the railroad cutting it is evident that the limestone is cut across by several irregular intrusions of the igneous rock. The limestone where seen is not greatly metamorphosed, though the lack of red color in the soil indicates that the associated shales and sandstones are considerably altered. The diabase mass forms a prominent hill lying north and west of the creek, and from the contour of this hill it is judged that the intrusion does not form the floor of the broad valley east of Beavertown. In the area between the diabase hill and South Mountain there are no rock exposures, except in the quarry above Beavertown. This opening has been made about a sink, and 50 feet of limestone conglomerate has been exposed. Other sink holes, extending in a northeast direction, suggest that the same stratum continues for fully a mile in a northeasterly direction along the edge of the Mesozoic belt. Beds of conglomerate may come into contact with the diabase beneath the deep mantle of soil on the west and northwest slopes of the hill, so that this ground may be worth prospecting.

In the neighborhood of Dillsburg the body of diabase which has been under consideration lies well within the Mesozoic area, but 2 miles north of town it lies between Mesozoic strata on the southeast and Paleozoic limestone on the northwest. In a limestone quarry one-half mile south-southeast of the $\mathrm{D}$. and M. Junction the limestone and diabase are seen almost in contact. The fact that the limestone shows no evidence of having been affected in any way by the diabase suggests that in this place the two rocks have been brought together by a fault. Though this structure can not be proved from the features to be seen in this quarry, there are strong reasons for believing that the boundary between the Mesozoic area and the older rocks of the valley and of South Mountain is formed by a profound fault for at least 25 miles southwest of the Susquehanna and for some distance east of that river. The probability that this fault exists and that movements have taken place along it since the intrusion of the diabase removes the contact with the Paleozoic limestones from consideration as a place in which ore bodies are to be expected.

Inasmuch as it is wholly impossible to estimate the thickness of the Mesozoic strata in the vicinity of Dillsburg or to judge either the distribution of the rocks which lie below these beds or the subter- 
ranean forms and courses of the intrusive mass of the diabase, no suggestions can be made concerning the possibility of ore deposits being present beneath the Mesozoic formations.

\section{GRANTHAM MINES.}

On the south side of Yellow Breeches Creek, near Grantham crossing, are situated three old mines, known as the Landis or Fuller, the Porter, and the. Shelley. Outerops in the railroad cuts and material on the mine dumps show that the deposits at this place occur in Mesozoic strata, which include beds of limestone conglomerate. North of Yellow Breeches Creek the bed rock is Paleozoic limestone, and just south of the mines diabase appears. This diabase is part of an intrusive mass of important size, extending westward and southwestward to the vicinity of Dillsburg and eastward for 4 miles or more to join a great mass of the same rock which forms the group of high hills between Dillsburg and Mount Airy. Just south of Grantham the intrusion is about 1 mile wide. Eastward from Rosegarden, its northern boundary is an irregular, waving line, which has not been traced in detail beyond Grantham. Near the mines the strata adjacent to the diabase are undoubtedly considerably disturbed, as is indicated by varying dips in the old workings. It seems, however, that the average ore-bearing beds decline gently toward the south and pass beneath the diabase, so that the latter forms a general hanging wall over the deposits. The Landis and Porter openings are situated just at the edge of the diabase, and at the Shelley mine a shaft is said to have penetrated diabase lying just above the ore. One mile up the railroad track from Grantham, at Rosegarden, diabase is seen along the tracks, and one-third mile farther west Paleozoic limestone appears only a short distance beyond the last outcrop of the igneous rock. Here, then, the diabase comes into contact with the older rocks. In the field south of the railroad débris revealed by gullies cut into the hill slopes shows the presence of sandstone beneath the diabase. These sandy beds can continue toward the west for a short distance only, for undoubted Paleozoic limestone is again observed very near the diabase on the highway just south of the crossroads. In the valley of the small brook which joins the creek at Rosegarden is an old prospecting shaft, situated at the south edge of the diabase mass. No indications of ore are to be seen in the material on the dump, but the amount of material thrown out indicates that considerable work was done at this place. The rock excavated is mainly a hard baked shale.

Northeast of Grantham, on the north side of the creek, is a mass of diabase which may have been separated from the main mass by the erosion of the creek channel. On the south side of this mass, in the wooded ravine about one-half mile east of the railroad, there is an old 
prospect pit in which baked sandstone occurs. Along the railroad track the diabase is to be seen in contact with Paleozoic limestone, but as the latter is not notably metamorphosed at this place it is thought that the contact is not an intrusive one, but that a fault has brought these two rocks together. This suggestion brings up the general structural problem presented by the northerly boundary of the Mesozoic belt throughout the State, discussion of which will not be attempted here.

In the fact that they occur between beds of limestone conglomerate and overlying diabase the ore deposits near Grantham resemble several of the deposits of the Dillsburg group, the same relation being observed in the Underwood, Longnecker, Jauss, Price, and Logan workings.

In the absence of any adequate data concerning the amount of iron ore that has been extracted from these mines and the degree of persistence shown by the ore bodies in the ground opened, it is difficult to judge whether prospecting in the vicinity for other deposits would be advisable or not. From a purely geologic standpoint conditions similar to those existing near the known ore bodies may be supposed to extend for a considerable distance both east and west of the old openings. The place to look for ore is evidently just beneath the diabase, and where conglomerate is present under the igneous rock ore is likely to be found. The most feasible way to make a test is by a line of drill holes located just within the boundary of the diabase area. Perhaps the most attractive scheme of prospecting would be to determine by means of the drill whether or not the deposits already known extend beyond the old workings in the direction of the dip.

The following data concerning the three old mines at Grantham are condensed from Frazer's report: ${ }^{a}$

The Landis mine was opened about 1863. A tunnel from the railroad and close to the banks of the creek enters a steep bank due south for 200 feet. Two drifts lead off west and east of the main tunnel. The hanging wall is diabase, dipping $24^{\circ} \mathrm{N} .25^{\circ} \mathrm{W}$.

Operations at the Porter mine were begun in 1855 . In 1875 the excavation was reported to be about 40 feet deep and 14 feet below the water in Yellow Breeches Creek. Ore was loaded from the pit into carts. The ore bed is said to have been from 3 to 6 feet thick, to have been opened for 25 feet along the strike, and to have dipped $30^{\circ}$ toward the creek.

At the Shelley mine 20 feet of diabase is reported above the ore. The ore bed was 10 feet thick and rested upon "Potomac marble"that is, upon limestone conglomerate.

${ }^{a}$ Second Geol. Survey Pennsylvania, Rept. CC, 1877, pp. 220-222. 
Frazer regarded the inclosing rock of the Porter ore as probably Paleozoic limestone. Though the rock exposed in the near-by cutting along the railroad was thought by him to be "Auroral limestone," the present writer is confident that it is limestone conglomerate belonging to the Mesozoic belt. These strata dip toward the south at a low angle. A thin sill of diabase is seen in contact with the calcareous rock, which is considerably metamorphosed.

The following notes are given by D'Invilliers: ${ }^{a}$

The old Fuller or Landis mine is owned and worked by Mr. Shelley, who states that a shaft 80 feet deep passed through diabase to a chimney-shaped bed of ore dipping north-northeast. The same ore was struck 100 feet farther east by a 40 -foot shaft, in which the ore also dips toward the creek. According to Mr. Shelley, there are four or five beds here, separated by short intervals of hard rock of a white color, and not unlike a baked slaty sandstone. In April, 1887, preparations were being made to sink on the outcrop of a lower bed showing about 100 yards south of the shaft.

Immediately across a narrow ravine to the east of this opening a large amount of ore was formerly raised by Mr. Fuller, and the operation is supposed to have been stopped owing to the occurrence of "Potomac marble," which cuts out the ore for a considerable extent through the mine and along the railroad. This rock shows largely through the field and along the track, where an abandoned cut developed a large body of soft surface ore, resulting from the decomposition of the bed, 5 to 8 feet thick, which was encountered in the bottom of the pit. Mr. Shelley says that there are 13 acres in this property through. which no pinching in the ore beds occurs, so far as developed.

\section{MINES SOUTHWEST OF WELLSVILLE.}

The so-called "Minebank" workings are situated about 2 miles southwest of Wellsville, and about $6 \frac{1}{2}$ miles from the northwest boundary of the Mesozoic belt (Pl. XIX). The most prominent feature in the local geology is a mass of intrusive diabase, which appears at the surface in an elliptical area about $2 \frac{1}{2}$ miles long and 1 mile wide. This diabase is surrounded by shales and sandstones which are bleached and baked in the vicinity of the igneous rock. The general strike of the strata is northeast and southwest, and dips, wherever observable, are toward the northwest, usually at moderate angles.

The "Minebank" deposit appears to be a layer conforming to the strata by which it is inclosed. It has been opened by a series of pits and shafts extending from southwest to northeast for a distance of about 1,000 feet along the strike of the outcrop, and indications of

a Ann. Rept. Geol. Survey Pennsylvania for 1886, pt. 4, 1887, pp. 1513-1514. 
ore were found in explorations beyond the northeasternmost and largest.mine, which is situated back of the schoolhouse. Although a narrow dike of diabase is said to have been encountered in one of the mines, the main intrusion lies some distance northwest of the ore cropping. The dip of the strata which inclose the ore is toward the diabase. The waste to be seen on the mine dump consists mainly of baked shale and fine-grained sandstone. Specimens may be seen in which joints crossing the stratification contain films of micaceous hematite. Lumps of solid ore may be found composed either of hematite and magnetite together, or of hematite alone. Some of the micaceous ore, which looks like specular hematite, yields a black powder instead of the red powder, which is characteristic of hematite, and is attracted by the magnet. A mass of similar ore is reported to have been mined out years ago from one of the Phoenix mines at Boyertown. Several blocks were noted which were composed of crystalline limestone and specular hematite with a sprinkling of chalcopyrite. A study of this material leaves little doubt that the iron mineral has been deposited through some process of chemical substitution. From the presence of the limestone it may be thought that the ore layer was formed by the replacement of a limestone stratum interbedded. with the shales and sandstones which are the common rocks of the region. Whether this be true or not, there can be little doubt that the ore was introduced through the agency of hot water or gases, impelled by the adjacent intrusive mass of diabase. From the description given below it appears that the mineralizing solutions followed the narrow dike or sill of diabase which was encountered in the mine. Though showings of ore have been reported at several places in the vicinity of the large diabase mass, no minable body of ore has been discovered aside from the one at Minebank. ${ }^{a}$

The following data are abstracted from Frazer's report: ${ }^{b}$

Ore was first discovered in the vicinity of the present workings about 1805. Prospecting in 1872 led to the opening of the Altland shaft, which passes through 5 feet of soil, then 25 feet of lightgreenish hard sandstone, below which a 6 -foot bed of micaceous ore was encountered. Beneath the ore was blue to gray sandstone, similar to that above except for being harder. The ore was followed by a slope until a diabase dike was encountered. The dip measured on the sandstone is $31^{\circ}$ to $35^{\circ} \mathrm{N}$. $30^{\circ} \mathrm{W}$. A second shaft was sunk in the same year, about 120 feet north of the first. In 1875 the gangways along the ore had a total length of about 500 feet. The ore lies between the sandstone in regular layers, varying from 6 inches to 7 feet in thickness, with occasional sandstone partings. It is in many places found cutting into the diabase. The boundary between the latter and the sandstone is very clearly defined. Ore had been found

a Second Geol. Survey Pennsylvania, Rept. CC, 1877, pp. 231-238.

${ }^{b}$ Op. cit., pp. 235-236. 
on the northwest side of the dike, but up to 1875 not in paying quantities. Sixty feet down the slope and 50 feet northwest of it both the sandstone and the diabase dip $30^{\circ} \mathrm{NW}$. The diabase is here 4 feet thick. Thirty feet north of the shaft, 2 or 3 yards of rock in contact with the dike showed no ore, but the vein had been proved from this point to the surface. The ore is very micaceous.

\section{BENDER MINE.}

Near the York Springs road, about a mile southwest of Dillsburg, are two old pits from which iron ore was formerly extracted. One of these is situated east of the road, very near the boundary of the intrusive diabase, at the south end of an embayment of sedimentary rocks. No exposures of rock in place are to be seen near this opening, but limestone conglomerate and red sandy shale occur in the quarry beside the road less than one-fourth mile to the north. The mine is reported to have been a small one. The second mine, known as the Bender property, is located about one-fourth mile farther southwest, on the west side of the wagon road. This deposit is said to have been opened in 1849 , in which year 200 tons of ore was extracted. In 1873 about 80 tons of ore was mined from a so-called pocket averaging 5 feet thick, lying under 7 feet of stripping. The mine was worked entirely by open pit. ${ }^{a}$

In the neighborhood of the Bender pit irregularly shaped masses of extremely hard and dense green rock may be found lying upon the surface or embedded in the soil. This flinty material is a much baked sedimentary rock, probably a limy shale or impure limestone in its original state. Some of the specimens examined are composed almost entirely of massive garnet; others contain considerable colorless pyroxene. Bowlders of this rock may be found in an area 300 to 400 feet long and about 100 feet wide. Soil derived from diabase is present on all sides of this patch, so that the strata with which the ore is associated evidently form an isolated mass, surrounded by the intrusive rock. The locality is near the west side of the diabase intrusion, here about one-half mile wide, which runs northeastward to Dillsburg and thence southeastward and eastward to join the great mass which forms the group of high hills between Stevenstown and Mount Airy. Southwest of Dillsburg this band of diabase has been followed for about 8 miles.

Flinty rock like that described above occurs on the east side of the diabase about a mile south of the Bender pit, but in this vicinity indications of ore are not known to have been found. From the occurrence of limestone conglomerate in the valley west of the Bender mine it seems possible that a bed of this rock may have been replaced in the formation of the ore deposit.

${ }^{a}$ Second Geol. Survey Pennsylvania, Rept. CC, 1877, p. $22 \dot{6}$. 


\section{INDEX.}

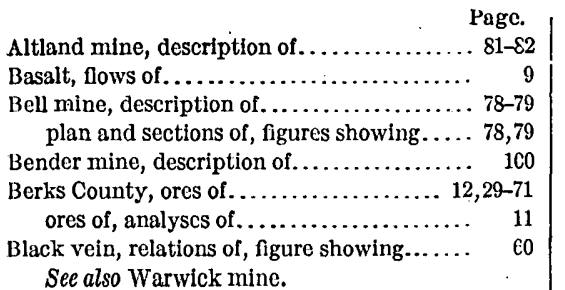

Blue vein, location of . . . . . . . . . . . 43,55

Boyertown, fault near.................. $\quad{ }_{58}$

fault near, position of, plate showing.... 56

geologic map of................... 44

geology near. . . . . . . . . . . . . . . . . . 44-46

maps near.................. 44,61, $\mathrm{C3}$

mines of, sections of, plate showing...... 46 workings of, plate showing $46,48,50,52,54,56$

ore deposits of . ................. 12,43-01

ore deposits near. .................61-C5

prospecting near................. 57-61

Brower mine, description of ............. C2

California mine, description of.... 47-48,50-51,56-58 plan of, plate showing............... 56

Cambrian quartzites, occurrence and character of

Cambro-Ordovician limestones, occurrence and character of....................

Casper mine, ores of. ................ 28-29

Chester County, ores of................. 12

Cobalt, occurrence of................... 11

Conglomerate, occurrence and character of. $18,43,73$

Congo, copper near................... C5

Cornwall, mines near, geologic map of...... 20

ore deposits at. . . . . . . . . . 17-28

distribution of $\ldots \ldots \ldots \ldots \ldots \ldots \ldots \ldots 17-19$

erosion of .................... 21

extent of.................... 21-28

intrusions in $\ldots \ldots \ldots \ldots \ldots \ldots \ldots \ldots . \quad 19$

structure of . . . . . . . . . . . . . . .

surface relations of . . . . . . . . . 17-18

See also Cornwall ore body.

ore deposits near. ............... 23-29

ores of ............................ 11

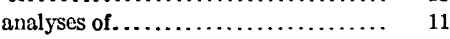

Cornwall district, geologic map of......... 18 ores of .......................... 17-29

structure sections of, plate showing.... 20 See also Cornwall.

Cornwall ore body, description of......... 22-23

Cox mine, description of............. 76-77

Diabase, intrusions of. ........... 9-10, passim

intrusions of, map showing. relation of, to ores..........
Page.

Dikes, occurrence and character of........ 9-10

Dillsburg, geologic map near........... 72,74

mines near. ...................... 71-75

description of................. $75-92$

diabase $n e a r . . \ldots \ldots \ldots \ldots \ldots \ldots \ldots . . \ldots 2-93$

map of . . . . . . . .

ores of................... 11,12

conclusions on.................. 93-90

D'Invillérs, E. V., on Altland mine....... 81-82

on Bell mine..................... 78

on Boyertown mines.............. 49-55

on Cox mines.................. 76-77

on Grantham mines................. 98

on Island mine .................. 38,40

on Randenbusch mine................. $\quad 30$

on Underwood workings............. 85

Drill holes, records of................. 24

East vein, location of.................. 43

structure near, map showing......... $\quad 59$

workings on ....................

Eckert vein, location of...............

workings on .................. 43,47-49

Esterly mine, description of ............ 41-43

Faulting. See Folding and faulting.

Fegley mine, ore from . ............... 64-65

Folding and faulting, prevalence of........ 8

Frazer, Persiflor, on Bell mine........... 79

on Grantham mines................ 97

on Jones mine vicinity............... 68-69

on McCormick inines................ 88-92

on Minnebank mine .................. 99-100

on Underwood workings.............. 84

Fritz Istand, geologic map of............. $\quad 38$

ore deposits on and near............. 38-41

sections on, figures showing........... 39

Fritztown station, geology near.......... 36

Fuller mine. See Landis mine.

Gabel mine, description of.......... $47,53-56$ geology of . . . . . . . .

plan of, plate showing ............. 44

section of........................ 53

figure showing................. 60

Geology, description of.............. 7-10

Gilbert shaft, ore from............... 63

Grantham mines, description of. . . .... 72,96-98

Grove mine, description of............... 77

Hagy vein, location of $\ldots \ldots \ldots \ldots \ldots \ldots 43,57-59$

structure near, map showing.......... $\quad 59$

workings on .................. 43

Harden, J. H., map by................ 47

Hummelstown, ores near................. 29

Igneous rocks, occurrence and character of... 9-10

Iron, source of. . . . . . . . . . . . . 
Page.

Island mine, description of

Jauss mine, description of . plan of, figure showing. section of, figure showing

Joanna station, ores near.

Jones mine, description of . . . . . . . . . . . 65-69 geologic map of. . . . . . . . . . . . . . . . 66

map of . . . . . . . . . . . . . 68

sections of, figures showing. . . . . . 66,67

King mine, description of.............. 79-81

Kinney mine, geology of.............. $60-\mathrm{C} 8$ map of . . . . section of, figure showing $\ldots \ldots \ldots \ldots \ldots 66-67$

Knauertown, ores near................ 71

Lancaster County, geology in............. 20

Landis mine, description of............... 96-98

Lebanon, ore deposits near. See Cornwall.

Lewis, J. V., on New Jersey copper........ 65

Logan mine, description of. .......... . . 75-76

Longnecker mine, description of. . . . . . . . 86-88 sections of, figures showing.... . . . . . 85,87

McCormick mines, description of . . . . . . . . 8 88-92 map of, figure showing............. 90 sections in .................... 88-99,91

McCreath, $\mathbf{\Lambda}$. S., analyses by ............. 11

Mesozoic rocks, occurrence and character of. $\quad 8-9$ occurrence and character of, map showing. 8,74

Metamorphism, occurrence and character of. 14-16 relation of, to ores. .............. 13,15-16

Mill Ridge, geology of. ................. 26

Minnebank. ore deposits near....... 71-72,98-100

Newark group. See Mesozoic rocks.

Nova Scotia, ores of

Ordovician shales, occurrence and character of

Ore deposits, occurrence and character of. 10,16-17 ores of. See Ores.

Ores, analyses of.

composition of................... 11

distribution of

geologic relations of................ 12

metamorphism of.................... 16

origin of $\ldots \ldots \ldots \ldots \ldots \ldots \ldots \ldots \ldots \ldots \ldots, 13-16$

See also particular mines.

Paleozoic rocks, occurrence and character of. $\quad .8$

Peckitt, Leonard, analyses by ............ . 11

Phoenix mines, descripition of........... 47-51

Porter mine, description of . . . . . . . . . . . 96-97

Price farm, prospects on.............. 77-78

Price mine, description of............. 77 is
Page.

Pyrite, occurrence of.................... 10

Raudenbusch mine, description of........ . 36-37

Reading, geologic map near............. 30

ores near......................... 12

Replacement deposits, occurrence and character of......................... 13

Reservoir, ores near. . . . . . . . . . . . . . . . 23-24

Rhoades and Ginn shaft, description of..... 62

IRhoades vein, location of . ............. 43,47 workings on ..................... 44,47

Richards, Richard, on Boyertown mines. . . 57,62

Rogers, H. D., on Jones mine............ 66 on Raudenbusch mine............... "' 36

on warwick mine.................69-70

Rowe, W. G., on Esterly mine.......... $41 ; 42$

Ruth mine, section at, figure showing...... 31

Schuylkill River, ore deposits on . . . . . . 40-41

Scope of paper.......................

Second Geological Survey of Pennsylvania,

on Paleozoic rocks............. 8

Sedimentary rocks, description of......... 8-9

Shale, occurrence and charactep of . . . . . . $45-46$

Shelley mine, description of............. 96-98

Simyser mine, description. of. . . . . . . . . . . . 82-83

South Mountain, geology at. ............. 73-74

Underwood workings, description of. . . . . . 83-86 section of, figure showing........... $\quad 85$

Warwick mine (Berks Co.), description of... 43$45,48-49,51-53,56$ map of, figure showing. ............. 48 plan of, plate showing . ............ 56 vein of, location of. ................ 43,57

Warwick mine (Chester Co.), description of. . 69-71 geologic map of $: \ldots \ldots \ldots \ldots \ldots \ldots \ldots \ldots . \quad 66$ section of, figure showing........... 69

Wellsville, mines near. ................ 98-100

Wheatfield group, description of . . . . . . . . 29-30

diabase and, relation of............ 30 geologic map of...................

ore deposits of, distribution of . . . . . . 34-36

ores of, character of ................. 31,35

structure at. . .................... 31-34

figure showing.............. 31,32,33

Willis, Bailey, on Boyertown mines . . . . . . . 47-49

York County, mines of, description of.... . 74-100 ore deposits in................. 71-100 ores from...................... 12 analyses of $\ldots \ldots \ldots \ldots \ldots \ldots \ldots \ldots, 11$ 